UNIVERSIDADE ESTADUAL PAULISTA “JULIO DE MESQUITA FILHO” FACULDADE DE CIÊNCIAS AGRONÔMICAS

CAMPUS DE BOTUCATU

\title{
CARACTERIZAÇÃO MORFOLÓGICA E ATRIBUTOS DE QUALIDADE DOS FRUTOS DE ACESSOS DE BANANEIRA EM \\ CLIMA SUBTROPICAL
}

\section{MANOEL EUZÉBIO DE SOUZA}

\begin{abstract}
Dissertação apresentada à Faculdade de Ciências Agronômicas da UNESP - Campus de Botucatu, para a obtenção do título de Mestre em Agronomia (Horticultura).
\end{abstract}

BOTUCATU-SP

Fevereiro - 2010 
UNIVERSIDADE ESTADUAL PAULISTA “JULIO DE MESQUITA FILHO” FACULDADE DE CIÊNCIAS AGRONÔMICAS

CAMPUS DE BOTUCATU

\section{CARACTERIZAÇÃO MORFOLÓGICA E ATRIBUTOS DE QUALIDADE DOS FRUTOS DE ACESSOS DE BANANEIRA EM \\ CLIMA SUBTROPICAL}

MANOEL EUZÉBIO DE SOUZA

Orientadora: $\operatorname{Prof}^{\mathrm{a}} \operatorname{Dr}^{\mathrm{a}}$ Sarita Leonel

Dissertação apresentada à Faculdade de Ciências Agronômicas da UNESP - Campus de Botucatu, para a obtenção do título de Mestre em Agronomia (Horticultura).

BOTUCATU-SP

Fevereiro - 2010 
FICHA CATALOGRÁFICA ELABORADA PELA SEÇÃO TÉCNICA DE AQUISIÇÃO E TRATAMENTO DA INFORMAÇÃO - SERVIÇO TÉCNICO DE BIBLIOTECA E DOCUMENTAÇ̄̃̂O - UNESP - FCA - LAGEADO - BOTUCATU (SP)

Souza, Manoel Euzébio de, 1984-

S731c Caracterização morfológica e atributos de qualidade dos frutos de acessos de bananeira em clima subtropical / Manoel Euzébio de Souza. - Botucatu : [s.n.], 2010.

$\mathbf{x}, 100 \mathrm{f}$. : il. color., gráfs., tabs.

Dissertação (mestrado) - Universidade Estadual Paulis-

ta, Faculdade de Ciências Agronômicas, Botucatu, 2010

Orientador: Sarita Leonel

Inclui bibliografia.

1. Bananeira - Produção. 2. Análise sensorial. 3. Bananeira - Qualidade dos frutos. 4. Bananeira - Crescimento. I. Leonel, Sarita. II. Universidade Estadual Paulista "Júlio de Mesquita Filho" (Campus de Botucatu). Faculdade de Ciências Agronômicas. III. Título. 


\title{
UNIVERSIDADE ESTADUAL PAULISTA "JÚLIO DE MESQUITA FILHO" FACULDADE DE CIÊNCIAS AGRONÔMICAS \\ CAMPUS DE BOTUCATU
}

\author{
CERTIFICADO DE APROVAÇÃO
}

TítUlO: "CARACTERIZAÇ̃̃o MORFOLÓGICA E ATRIBUTOS DE QUALIDADE DOS FRUTOS DE ACESSOS DE BANANEIRA EM CLIMA SUBTROPICAL"

ALUNO: MANOEL EUZÉBIO DE SOUZA

ORIENTADOR: PROFª ${ }^{\mathrm{a}}{ }^{\mathrm{a}}$ SARITA LEONEL

Aprovado pela Comissão Examinadora
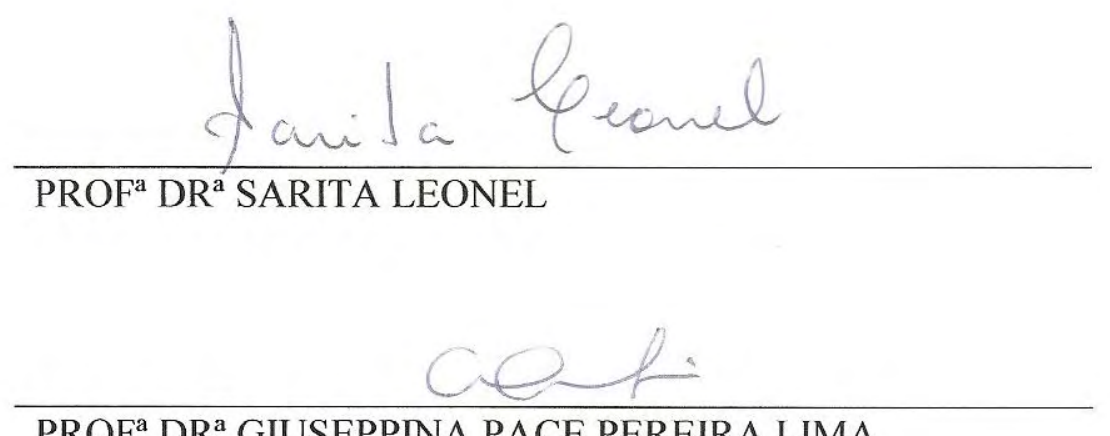

PROF $^{a}$ DR $^{\mathrm{a}}$ GIUSEPPINA PACE PEREIRA LIMA

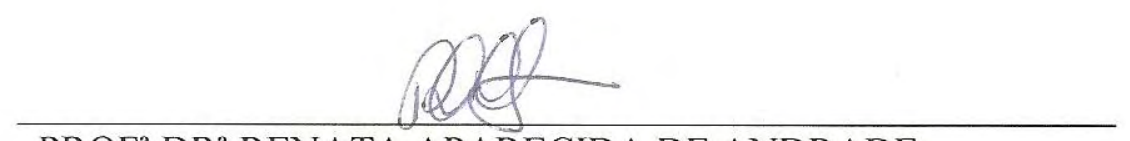

PROF $^{a}$ DR $^{a}$ RENATA APARECIDA DE ANDRADE

Data da Realização: 09 de Fevereiro de 2010. 


\section{Homenagem Especial}

\section{OFEREÇO}

A minha querida mãe, que com todo seu amor e carinho sempre esteve ao meu lado, amparando-me nas derrotas e sorrindo com as minhas vitórias. 


\section{AGRADECIMENTOS}

A Deus, por me dar forças nos momentos de dificuldades e desânimo.

À minha querida família, em especial minha mãe, que acreditou em mim, dando-me o apoio necessário para que eu pudesse lutar pelos meus sonhos.

À minha querida orientadora, $\operatorname{Prof}^{\mathrm{a}} \operatorname{Dr}^{\mathrm{a}}$ Sarita Leonel, que me recebeu de braços abertos e com muita humildade e paciência concedeu-me a oportunidade de conhecer o universo da fruticultura.

À Faculdade de Ciências Agronômicas- UNESP/Campus de Botucatu, pela estrutura concedida e o apoio para a realização deste trabalho.

Ao Programa de Pós-Graduação em Horticultura, por financiar o projeto deste trabalho e permitir a sua execução.

À banca examinadora, pela disponibilidade e sugestões que contribuíram para a melhoria do trabalho.

Aos meus mais que amigos, verdadeiros irmãos: Edvar, Andréa e Adilson que incansáveis me deram muito apoio durante a realização deste trabalho.

À minha querida amiga Dayana que, com muita humildade, sempre esteve à disposição, tirando minhas dúvidas a respeito do trabalho.

À querida amiga Edilene que, com muita dedicação, contribuiu diretamente na realização das análises sensoriais.

Aos amigos Alexandre e Rafaela, pela ajuda nos trabalhos de campo e nas análises de laboratório.

Aos amigos do Grupo de Oração Divina Misericórdia, em especial à Bárbara e Sandra pela motivação concedida.

À Márcia e Edivaldo, por me ajudarem em algumas análises realizadas no laboratório. 


\section{SUMÁRIO}

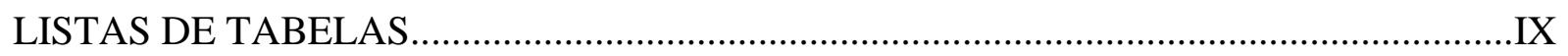

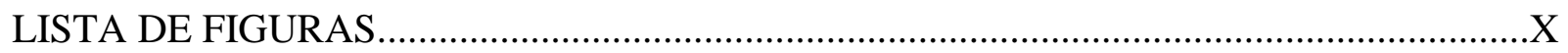

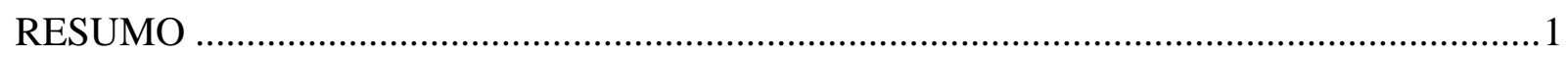

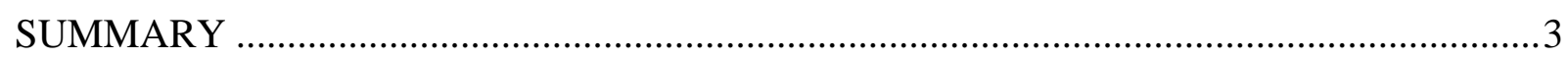

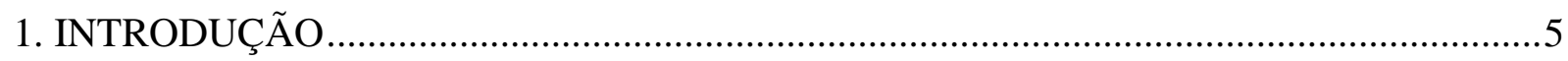

2. REVISÃO DE LITERATURA ............................................................................. 7

2.1. Mercado e potencialidades para a bananicultura ................................................

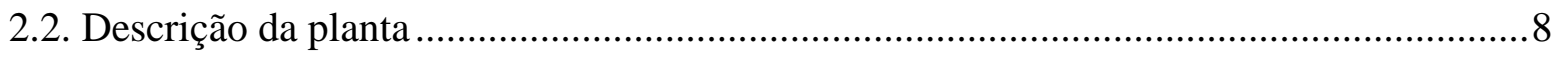

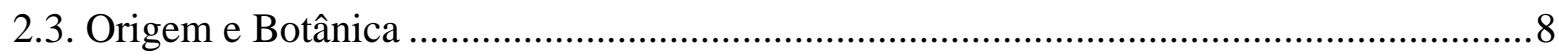

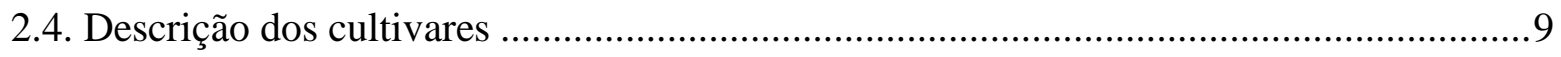

2.5. Clima para a bananicultura .............................................................................. 12

2.6. Adaptação dos cultivares em diferentes regiões .......................................................13

2.7. Qualidade dos frutos de bananeira ................................................................. 14

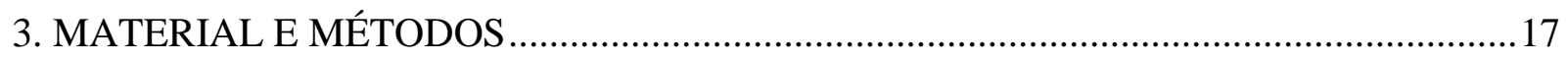

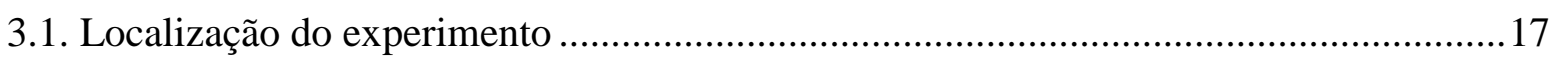

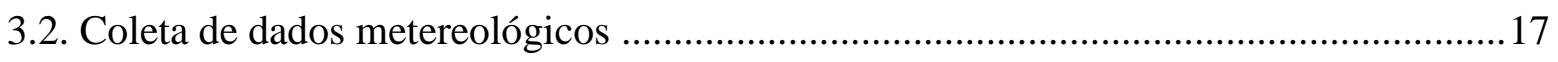

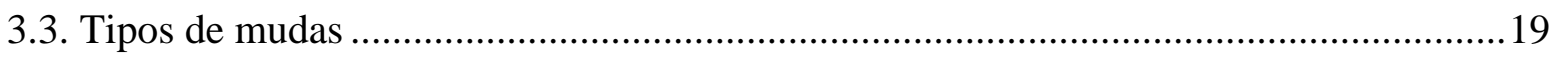

3.4. Implantação da área experimental .................................................................... 19

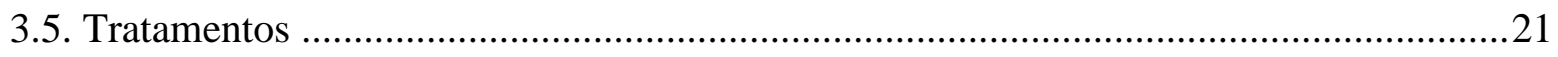

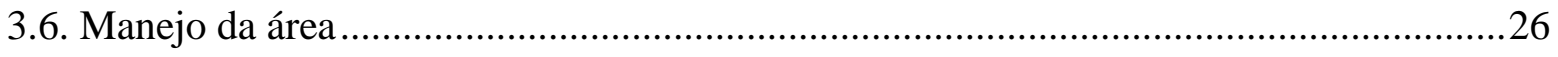




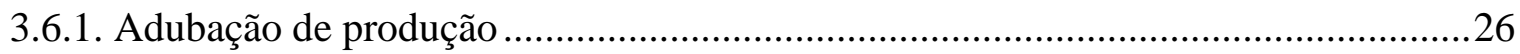

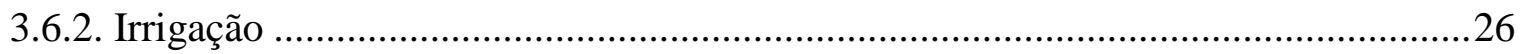

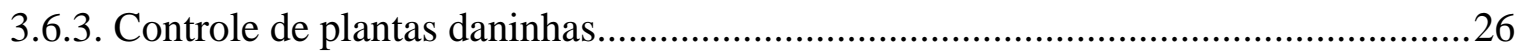

3.6.4. Controle de Pragas e Doenças ..............................................................................2

3.6.5. Retirada de folhas secas ...................................................................................2

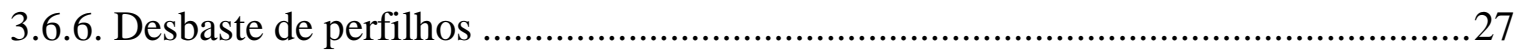

3.6.7. Retirada do coração .........................................................................................2

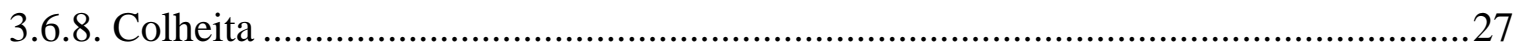

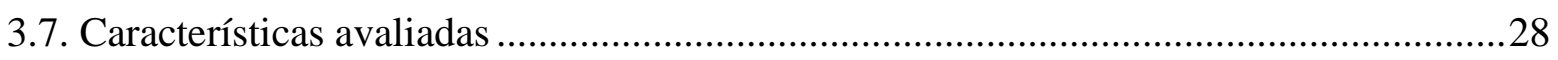

3.7.1. Características de crescimento e duração do ciclo ...................................................28

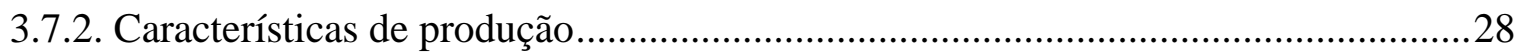

3.7.3. Características de qualidade dos frutos ...................................................................29

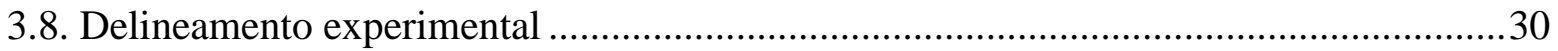

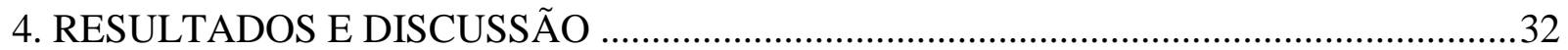

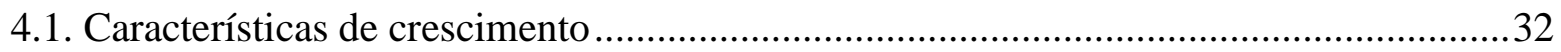

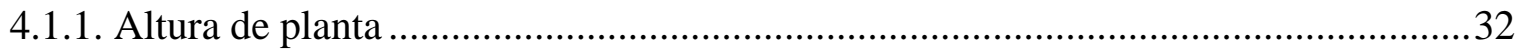

4.1.2. Circunferência do pseudocaule …………………...................................................37

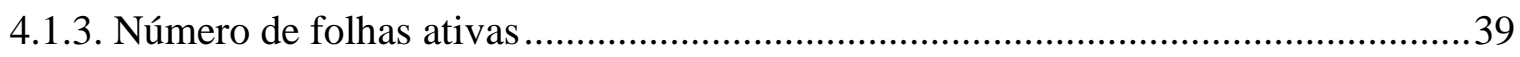

4.1.4. Número de dias do florescimento a colheita .........................................................41

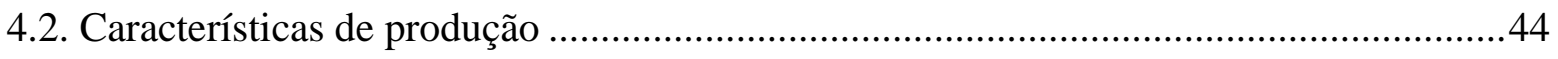

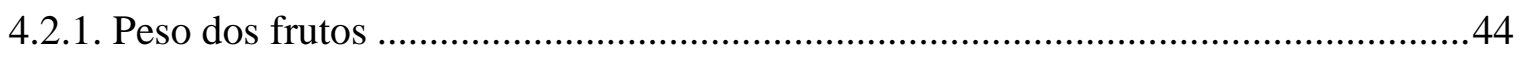




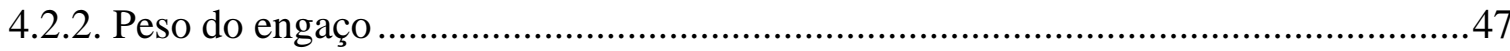

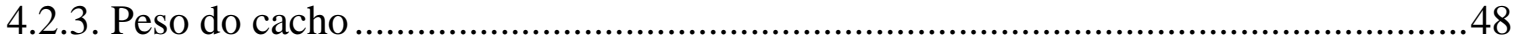

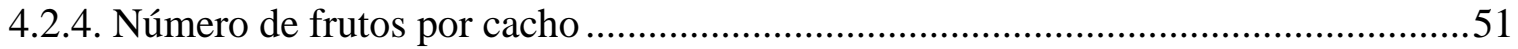

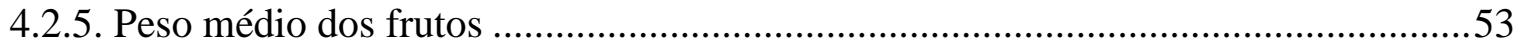

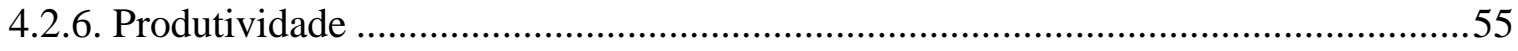

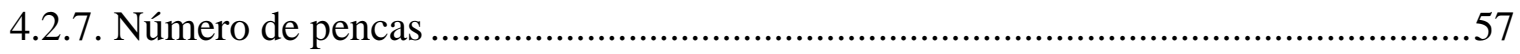

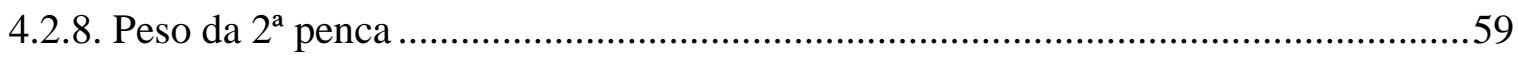

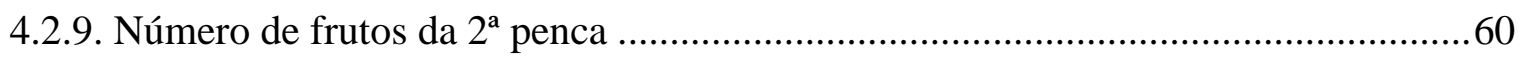

4.2.10. Comprimento dos frutos da $2^{\mathrm{a}}$ penca.............................................................62

4.2.11. Diâmetro dos frutos da $2^{\mathrm{a}}$ penca......................................................................64

4.3. Características de qualidade dos frutos ......................................................................65

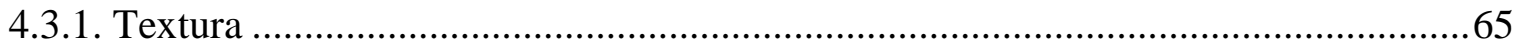

4.3.2. $\mathrm{pH}$

4.3.3. Acidez Titulável (AT) .....................................................................................

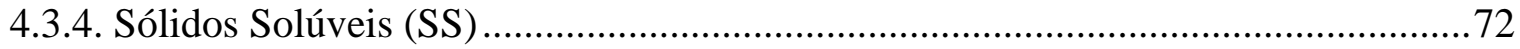

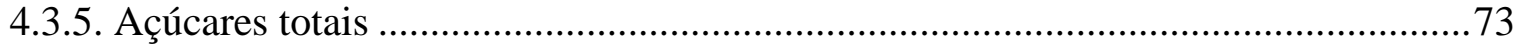

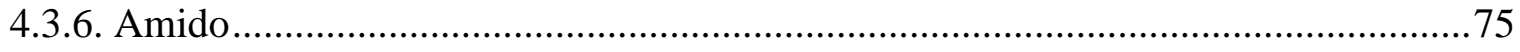

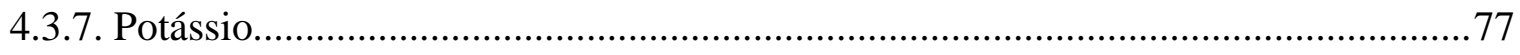

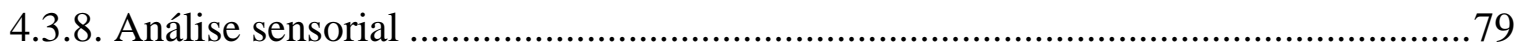

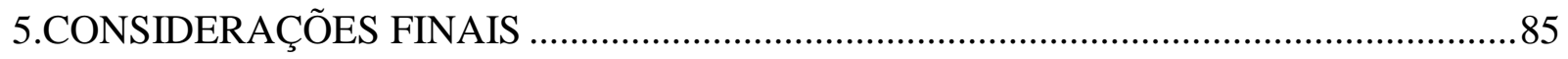

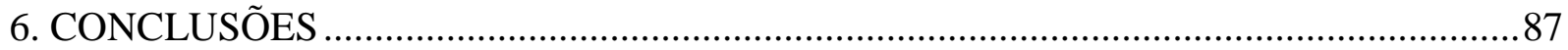




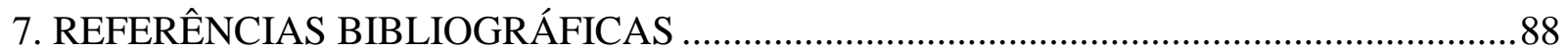

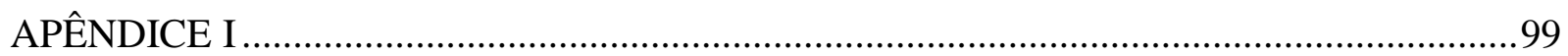

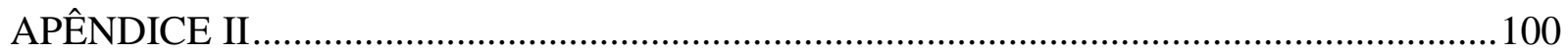




\section{LISTA DE TABELAS}

TABELA 01. Médias mensais das temperaturas máxima, mínima e média $\left({ }^{0} \mathrm{C}\right)$ e

Página precipitações pluviométricas $(\mathrm{mm})$ correspondentes ao ano de $2008 \mathrm{e}$ 2009- FCA/UNESP/ Botucatu-SP

TABELA 02. Análise química do solo da área experimental referente a fevereiro de 2008 e fevereiro de 2009 - FCA/UNESP/ Botucatu-SP.

TABELA 03. Valores médios de altura da planta, circunferência do pseudocaule, número de folhas por planta e número de dias do florescimento à colheita de acessos de bananeira, Botucatu/SP (março de 2008 a maio de 2009)

TABELA 04. Valores médios de peso de frutos (PF), peso do engaço (PENG), peso do cacho $(\mathrm{PC})$, número de frutos por cacho $\left(\mathrm{N}^{\circ} \mathrm{F}\right)$, peso médio dos frutos (PMF) e produtividade (PROD) de acessos de bananeira, Botucatu-SP (março de 2008 a maio de 2009)

TABELA 05. Valores médios de número de pencas $\left(\mathrm{N}^{\circ} \mathrm{P}\right)$, peso da $2^{\circ}$ penca $\left(\mathrm{P} 2^{\circ} \mathrm{P}\right)$, número de frutos na $2^{\circ}$ penca $\left(\mathrm{F} 2^{\circ} \mathrm{P}\right)$, comprimento $(\mathrm{CF})$ e diâmetro de frutos (DF) de acessos de bananeiras, Botucatu-SP (março de 2008 a maio de 2009)

TABELA 06. Valores médios de textura, pH, acidez titulável (AT), sólidos solúveis (SS) de frutos de acessos de bananeira, Botucatu-SP (março de 2008 a maio de 2009)

TABELA 07. Valores médios de açúcares totais (AT), amido e teor de potássio (K) de frutos de acessos de bananeira, Botucatu-SP (março de 2008 a maio de 2009)

TABELA 08. Valores médios de textura, pH, acidez titulável (AT) e sólidos solúveis da polpa de frutos maduros de acessos de bananeira Botucatu-SP (março de 2008 a maio de 2009. 


\section{LISTA DE FIGURAS}

Página

FIGURA 01. Bananal onde foi realizado o experimento - Botucatu-SP/ 2009.

FIGURA 02. Cacho do cultivar de bananeira 'Figo Cinza', do grupo genômico ABB Botucatu-SP/2009.

FIGURA 03. Cachos de cultivares de bananeira do grupo genômico AAA, BotucatuSP/2009.

FIGURA 04. Cachos de cultivares de bananeira do grupo genômico AAB, BotucatuSP/2009.

FIGURA 05. Cachos de híbridos de bananeira do grupo genômico AAAB, Botucatu SP/2009.

FIGURA 06. Atributos de aparência, aroma, textura, sabor e AVG (avaliação global) da polpa dos frutos de genótipos de bananeira do grupo AAA, FCA/UNESP-Botucatu-SP/2009.

FIGURA 07. Atributos de aparência, aroma, textura, sabor e AVG (avaliação global) da polpa dos frutos de genótipos de bananeira do grupo AAB, FCA/UNESP-Botucatu-SP/2009.

FIGURA 08. Atributos de aparência, aroma, textura, sabor e AVG (avaliação global) da polpa dos frutos de genótipos de bananeira do grupo AAAB, FCA/UNESP-Botucatu-SP/2009.

FIGURA 09. Atributos de aparência, aroma, textura, sabor e AVG (avaliação global) da polpa dos frutos do cultivar de bananeira do grupo ABB, FCA/UNESP-Botucatu-SP/2009. 
CARACTERIZAÇÃO MORFOLÓGICA E ATRIBUTOS DE QUALIDADE DOS FRUTOS DE ACESSOS DE BANANEIRA EM CLIMA SUBTROPICAL. Botucatu, 2010. 100 p. Dissertação (Mestrado em Agronomia / Horticultura) - Faculdade de Ciências Agronômicas, Universidade Estadual Paulista.

Autor: MANOEL EUZÉBIO DE SOUZA

Orientadora: SARITA LEONEL

\section{RESUMO}

Sabendo da importância da bananicultura para o Brasil, sobretudo para o Estado de São Paulo e a expansão de novos cultivos, o presente trabalho teve como objetivo avaliar o desempenho agronômico, caracterizar atributos de qualidade, bem como aspectos sensoriais dos frutos de acessos de bananeira em Botucatu/SP. Foram avaliadas características de crescimento, tais como altura de planta, circunferência do pseudocaule, número de folhas e número de dias entre o florescimento e a colheita. Estas medidas foram feitas na emissão da inflorescência. Foram mensuradas também as características de produção, como peso do cacho, número de frutos, peso médio dos frutos, produtividade, número de pencas; peso, número, comprimento e diâmetro dos frutos da $2^{\mathrm{a}}$ penca. Em relação à qualidade dos frutos foram, analisados os atributos físicos e químicos: textura; $\mathrm{pH}$; acidez titulável; sólidos solúveis, açúcares redutores totais; amido e potássio, bem como a aceitação desses acessos através da análise sensorial. $\mathrm{O}$ delineamento adotado foi o inteiramente casualisado, com 12 tratamentos (acessos), 5 repetições e duas plantas úteis por parcela experimental. Foi utilizado o teste de Tukey $(P \leq 0,05)$ para a comparação entre as médias de genótipos, dentro de cada grupo genômico. No grupo AAA, 'Grand Naine' apresentou boas características de crescimento, produção e boa aceitação sensorial, porém teve ciclo longo. 'Nanicão' apresentou boas características de crescimento, produção, qualidade e boa aceitação sensorial. 'Caipira' destacou-se apenas nos teores de potássio. 'Nam' apresentou porte baixo, ciclo curto e maior teores de açúcares, entretanto mostrou-se pouco produtiva. No grupo AAB, 'Thap Maeo' apresentou menor ciclo, maior número de frutos por cacho, porém apresentou porte alto. 'Prata Anã 'apresentou porte mais baixo e frutos com boa firmeza. O cultivar Prata Zulu apresentou frutos com maiores teores de açúcares e amido, baixa acidez, boa firmeza, mas apresentou 
porte alto. Em relação ao grupo AAAB, o híbrido 'Fhia 01' apresentou boas características de produção, porém baixa aceitação sensorial. 'Prata Graúda' apresentou boas características de produção e melhor aceitação sensorial. 'Fhia 18' teve boa produção, maiores teores de açúcares e boa aceitação. 'Maçã Tropical' apresentou o menor ciclo. 'Figo Cinza', do grupo $\mathrm{ABB}$, apresentou frutos menos ácidos, porém ciclo longo, porte elevado e baixo potencial produtivo, com aceitação indiferente pelos provadores. Conclui-se portanto, que no grupo AAA, os cultivares que se destacaram foram Grand Naine e Nanicão, no grupo AAB foi o cultivar Prata Zulu e o híbrido ‘Prata Graúda' foi o melhor do grupo AAAB.

Palavras chave: crescimento, produção, aceitação sensorial 
MORPHOLIGICAL CHARACTERIZATION AND QUALITY ATTRIBUTES OF FRUITS OF BANANA ACCESSES IN SUBTROPICAL CLIMATE. Botucatu, 2010. 100 p. Dissertação (Mestrado em Agronomia/Horticultura) - Faculdade de Ciências Agronômicas, Universidade Estadual Paulista.

Author: MANOEL EUZÉBIO DE SOUZA

Adviser: SARITA LEONEL

\section{SUMMARY}

Knowing the importance of the culture of banana in Brazil, especially for the São Paulo State, Brazil and the expansion of new crops, the objective of this research was to evaluate the agronomic performance, to characterize the quality attributes and sensory aspects of fruits of different accesses of banana tree in Botucatu/SP. Were evaluated growth characteristics such as plant height, pseudostem circumference, number of leaves, number of days between flowering and harvest, measured at the flowering time. Were also measured production characteristics, such as bunch weight, number fruits, average weight of the fruits, productivity, number of hands and weight, number, length and diameter of the $2^{\text {nd }}$ bunch. For quality fruit were analyzed physical and chemical characteristics: firmness, $\mathrm{pH}$, titratable acidity, soluble solids, total sugars, starch and potassium, and the acceptance of these genotypes by sensory analysis. The experimental design was completely randomized with 12 treatments (accesses), 5 replications and 2 plants per plot. Was used the Tukey test $(\mathrm{P} \leq 0.05)$ for the comparison between the means of accesses within each genomic group. According to the results of the Group AAA, 'Grand Naine' showed good growth characteristics, production and good sensory acceptance, but had long cycle. 'Nanicão' showed good growth characteristics, production, quality and good sensory acceptance. Caipira was the cultivar that showed more negative characteristics, highlighting only the levels of potassium. 'Nam' showed low height, short cycle and higher sugar content, however it was not very productive. In the group AAB, 'Thap Maeo' showed short cycle and higher number of fruits per bunch, but had high height. 'Prata Anã' showed low height and fruit firmness. The cultivar Prata Zulu showed fruit with higher concentrations of sugars and starch, low acidity, good firmness, but showed a high height. In the AAAB group, the hybrid 'Fhia 01' showed good characteristics 
of production, but low sensory acceptance. 'Prata Graúda' showed good production and better sensory acceptance. 'Fhia 18' showed good production, higher sugar content and good sensory acceptance. 'Maçã Tropical' showed the lower cycle. 'Figo Cinza', from the ABB group, showed fruit less acids, but it showed a long cycle, high height, low productive potential and indifferent sensory acceptance. The conclusions are that Grand Naine and Nanicão cultivars were the betters in the AAA group. In the AAB group was the Prata Zulu cultivar, while that the hybrid 'Prata Graúda' was the best of AAAB group.

Keywords: growth, production, sensory acceptance 


\section{INTRODUÇÃO}

A banana é a fruta tropical mais degustada e a segunda mais colhida no mundo. Nutritiva, acessível à maioria da população e disponível o ano todo, é o quarto produto alimentar mais consumido no mundo. No Brasil, a banana perde apenas para laranja em volume de produção (ANUÁRIO BRASILEIRO..., 2009).

O Brasil produziu em 2008 o equivalente a 7.217.824 toneladas de banana, cultivadas em uma área correspondente a $537.630 \mathrm{ha}^{-1}$, sendo Bahia, São Paulo, Santa Catarina, Pará, Minas Gerais, Ceará e Pernambuco os principais responsáveis pela produção nacional. São Paulo é o segundo maior produtor com uma produção de 1.222,820 toneladas (ANUÁRIO BRASILEIRO..., 2009). Explorada em sua maioria por pequenos agricultores, a cultura da bananeira exerce importante papel socioeconômico em muitos países emergentes, contribuindo não só para a geração de renda, mas também para a fixação da mão-de-obra no meio rural. Estimativas dão conta de que a cultura é responsável por mais de 500 mil empregos diretos (ANUÁRIO BRASILEIRO..., 2009).

Apesar do grande número de cultivares existentes no Brasil, considerando a preferência dos consumidores, produtividade, altura de plantas, tolerância às pragas e doenças, porte reduzido, resistência ao frio e à seca e frutos de qualidade apresentando boas características pós-colheita e organolépticas, são poucas as que apresentam potencial agronômico com fins comerciais. 
Uma das estratégias para a solução dos entraves mencionados é a seleção de novos cultivares resistentes às doenças, nematóides e pragas, mediante o melhoramento genético que possibilita a obtenção de cultivares superiores. A etapa final do processo consiste na avaliação dos cultivares em áreas de produção (SILVA et al., 1998; SILVA, 2000). As características analisadas em trabalhos de tal natureza são: ciclo da cultura, altura da planta, peso do cacho, número de frutos e comprimento do fruto (ALVES, 1990; LEDO et al., 1997).

Sabendo da importância da bananicultura para o Brasil, sobretudo para o Estado de São Paulo e a expansão de novos cultivos, o presente trabalho teve como objetivo avaliar o desempenho agronômico, caracterizar atributos de qualidade, bem como aspectos sensoriais dos frutos de acessos de bananeira em Botucatu/SP. 


\section{REVISÃO DE LITERATURA}

\subsection{Mercado e potencialidades para a bananicultura}

Segundo a FAO (2008), a produção mundial de frutas tropicais crescerá 82,2 milhões de toneladas em 2014, representando um incremento anual de 1,7 por cento. Essas informações são importantes para os produtores brasileiros, que encontram oportunidades no mercado exterior, possibilitando a exportação de frutas consideradas exóticas em países de clima temperado (MERCADO, 1997). Um dos maiores pólos mundiais de produção, e igualmente grande fornecedor internacional de inúmeras espécies, o Brasil explora suas peculiaridades de clima e de solo, de extensão territorial, de vocação de cultivo e de proximidades logísticas para fazer da fruticultura uma das principais atividades do agronegócio (ANUÁRIO BRASILEIRO..., 2009).

A produção de frutas frescas em 2008 chegou a 4,5\%, ao passo que as frutas processadas avançaram 11,5\% em relação ao ano de 2007 (IBGE 2008). Colhem-se em todo o mundo cerca de 69 milhões de toneladas de banana por ano, respondendo a Ásia e as Américas por quase $90 \%$ deste total. Dentre os maiores produtores de frutos destacam-se a Índia e o Brasil (VIEIRA, 2004).

Apesar do volume de produção, as exportações brasileiras representam apenas 3 a $4 \%$ do total nacional, rendendo cerca de US\$ 30 milhões anuais. As vendas se destinam aos países do Mercosul, em especial Argentina e Uruguai. Devido a falta de maiores 
cuidados na pós-colheita e no transporte, atribui-se a organização comercial deficiente um dos fatores impeditivos da maior presença do fruto brasileiro no exterior. O elevado consumo interno é visto também como fator limitante do incremento das exportações (VIEIRA, 2004).

\subsection{Descrição da planta}

A bananeira é uma planta herbácea, caracterizada pela exuberância de suas formas e dimensões das folhas. Possui tronco curto e subterrâneo, denominado de rizoma, onde se inserem as raízes adventícias e fibrosas. O pseudocaule, resultante da união das bainhas foliares, termina com uma copa de folhas longas e largas, com nervura central desenvolvida. Do centro da copa emerge a inflorescência com brácteas ovaladas de coloração normalmente roxo-avermelhada, em cujas axilas nascem as flores, onde cada grupo de flores reunidas forma uma penca (mão) com número variável de frutos (dedos), formados por partenocarpia (DANTAS et al., 1999).

\subsection{Origem e Botânica}

A maioria dos cultivares de bananeira originaram-se do Continente Asiático, embora existam centros secundários de origem na África Oriental e nas ilhas do Pacífico, além de um importante centro de diversidade na África Ocidental. De acordo com Moreira (1987), a palavra banana é originária das línguas serra-leonesa e liberiana da costa ocidental da África. Apesar de não saber sua origem com exatidão, admite-se que seja do oriente, sul da China ou da Indochina.

A bananeira é uma planta monocotiledônea, da ordem Scitamineae, família Musaceae, com dois gêneros: Musa e Ensete. O gênero Musa apresenta quatro subgêneros: Australimusa, Callimusa, Rhodoclamys e Eumusa. O subgênero Eumusa é o mais importante, pois agrupa as variedades de banana comestíveis (SIMÃO, 1985).

As variedades foram agrupadas por Simmonds (1960) baseando-se na origem biespecífica, por admitir que as atuais variedades tiveram origem de duas espécies selvagens, Musa acuminata e Musa balbisiana. Na evolução das bananeiras comestíveis participaram, principalmente as espécies selvagens diplóides $M$. acuminata e M. balbisiana, de modo que cada cultivar deve conter combinações variadas de genoma completos dessas 
espécies parentais. Esses genomas são denominados pelas letras A $(M$. acuminata) e B $(M$. balbisiana), de cujas combinações resultaram os grupos $\mathrm{AA}, \mathrm{BB}, \mathrm{AB}, \mathrm{AAA}, \mathrm{AAB}, \mathrm{ABB}$, AAAA, AAAB, AABB e ABBB (DANTAS ; SORARES FILHO, 1997).

Os cultivares possuem três níveis cromossômicos distintos: diplóides, triplóides e tetraplóides. Por meio de cruzamentos experimentais pode-se constatar que as bananeiras triplóides originaram a partir de hibridações entre diplóides, bem como os tetraplóides foram gerados a partir de cruzamentos entre diplóides de triplóides (DANTAS ; SOARES FILHO, 1997).

\subsection{Descrição dos cultivares}

O cultivar Nanicão-IAC-2001 foi selecionado pelo IAC - Instituto Agronômico de Campinas, em parceria com o Grupo Matsuda. É indicado para todas as regiões do país, pois se apresenta totalmente resistente à Sigatoka amarela (Mycosphaerella musicola). Dependendo do manejo, também pode apresentar boa resistência à Sigatoka negra (Mycosphaerella fijiensis). O peso médio de seus cachos chega a 35,7 Kg, produzindo até 11 pencas cada um, a textura da casca do fruto é macia e espessa, de coloração amarelo-clara, sendo que a polpa é pouco farinácea, de cor levemente creme, cujo paladar é menos adocicado que a 'Nanicão', bem como o aroma, que também é menos intenso. Seu tempo de prateleira vai de 4 a 5 dias a mais do que a 'Nanicão', com teor de vitamina $C$ três vezes maior, oferecendo assim, melhor digestibilidade para o consumo humano (MOREIRA, 2003).

O cultivar Thap Maeo, selecionado na Embrapa Mandioca e Fruticultura, em Cruz das Almas-BA, é um variante da 'Mysore'. Apresenta pseudocaule menos manchado, maior vigor e cachos maiores. Sua capacidade produtiva é de 30 t.ha $^{-1}$ a 35 t.ha ${ }^{-1}$, quando cultivado em solos de boa fertilidade, sob condições de sequeiro, usando as práticas culturais recomendadas para a cultura. Apesar de rústico, recomenda-se que seu cultivo seja feito em solos profundos, bem drenados e realizadas as adubações de rotina. Pertencente ao grupo genômico AAB, apresenta porte alto, ciclo vegetativo de 394 dias e bom perfilhamento. $\mathrm{O}$ peso dos cachos pode atingir 30 a $35 \mathrm{Kg}$, tendo cachos com mais de 10 pencas e até 250 frutos/cacho. É resistente à Sigatoka-negra, Sigatoka-amarela e ao Mal-dopanamá (hífen) (Fusarium oxysporum f. sp. Cubense), moderadamente resistente à Broca-do- 
rizoma (Cosmopolite sordidus) e ao nematóide cavernícola (Radopholus similis) e suscetível ao Moko (Pseudomonas solanacearum) (FANCELLI, 2003).

O cultivar Caipira é um cultivar introduzido da África Ocidental. Pertencente ao grupo genômico AAA que apresenta porte médio a alto, ciclo vegetativo de 383 dias, perfilhamento abundante, peso dos cachos podendo atingir $40 \mathrm{Kg}$, cachos com mais de 10 pencas, produzindo até 360 frutos/cacho. É uma planta rústica, com pseudocaule verdeamarelo-pálido, com manchas escuras próximas à roseta foliar. As folhas são eretas e estreitas, com margens dos pecíolos avermelhadas. Atinge uma altura de 2,5 a 3,5 m. É resistente à Sigatoka-negra, Sigatoka-amarela, Mal-do-panamá e à Broca-do-rizoma e suscetível ao Moko e ao nematóide cavernícola. (SILVA et al., 1999).

'FHIA 18' é um tetraplóide (AAAB) desenvolvido pela Fundação Hondurenha de Investigação Agrícola, na América Central. Os frutos de $15 \mathrm{~cm}$ de comprimento são de sabor doce e semelhantes ao tipo 'Prata'. A planta apresenta porte baixo/médio, ciclo vegetativo de 353 dias, perfilhamento bom. Os cachos podem atingir até 40 $\mathrm{Kg}$, com mais de 10 pencas e produtividade superior a 20 t.ha $^{-1}$. É resistente à Sigatoka-negra, moderadamente resistente à Sigatoka-amarela e suscetível ao Moko e ao Mal-do-panamá (FANCELLI, 2003).

O cultivar Prata Anã, também conhecido por 'Enxerto' ou 'Prata-deSanta-Catarina, pertence ao grupo genômico AAB. É uma planta bastante vigorosa e dispensa escoramento. Apresenta porte de médio a baixo (2,0 a 3,5 m), sendo seus frutos idênticos aos do cultivar Prata, com relação à forma e ao sabor, porém um pouco mais curto e roliço. Os cachos pesam de 14 a $16 \mathrm{Kg}$ e possuem 8 pencas, com 100 frutos em média, rendimento de 24 t/ha/ciclo e ciclo vegetativo de 407 dias. É tolerante ao frio, susceptível à Sigatoka amarela e negra e ao Moko, medianamente susceptível ao Mal-do-panamá, medianamente resistente aos nematóides e Broca-do-rizoma (BORGES et al., 1998).

O cultivar Prata Zulu, originário da África, possui porte alto, ciclo vegetativo de 401 dias na região Amazônica, possui perfilhamento bom, o pseudocaule e as folhas apresentam mais cera que os cultivares do subgrupo 'Prata', seus cachos pesam entre 20 e $25 \mathrm{~kg}$, com mais de 10 pencas, tem alta capacidade produtiva, tendo como produtividade esperada 33 toneladas no primeiro ciclo e chegando a 49,9 toneladas no segundo ciclo, sendo 
que seus frutos apresentam o pedúnculo rígido, o que lhes confere maior resistência ao despencamento, característica que favorece o transporte a longas distâncias. Nos testes de degustação, o cv (cultivar). Prata Zulu apresentou frutos com sabor agridoce e polpa acinzentada com consistência pegajosa. Outra importante característica deste cultivar é ser altamente resistente à Sigatoka-negra e à Sigatoka-amarela, principais doenças fúngicas para a cultura. No entanto é suscetível ao Moko, Mal-do-panamá, Broca-do-rizoma e ao nematóide cavernícola. (FANCELLI, 2003).

'Prata Graúda' é um híbrido tetraplóide do grupo AAAB, de porte médio, gerado em Honduras a partir do cruzamento de 'Prata Anã' com o híbrido diplóide SH 3393. Possui frutos e produção maiores que os da 'Prata Anã', com sabor um pouco mais ácido, sendo plantado comercialmente. Não apresenta resistência às Sigatokas amarela e negra, sendo, porém, resistente ao Mal-do-Panamá (SILVA et al., 2000).

'FHIA 01' é um híbrido tetraplóide (AAAB) introduzido de Honduras, que produz frutos do tipo Prata. Apresenta porte alto, ciclo vegetativo de 353 dias, perfilhamento bom, cacho com peso de $24 \mathrm{Kg}$, com cerca de 10 pencas. É resistente à Sigatoka-negra e Sigatoka-amarela e suscetível ao Moko (FANCELLI, 2003).

'Maçã Tropical' é um híbrido tetraplóide do grupo AAAB, resultante do cruzamento da variedade Yangambi $\mathrm{n}^{\circ} 2$ com o híbrido diplóide (AA) M53, de porte médio a alto, criado pela Embrapa Mandioca e Fruticultura. Os frutos são maiores, mais grossos e com sabor semelhante aos da variedade Maçã. É resistente à Sigatoka-amarela e tolerante ao Mal-do-Panamá. (SILVA et al., 2004).

Grand Naine é um cultivar pertencente ao grupo AAA, subgrupo Cavendish, apresenta porte intermediário entre a 'Nanica' e a 'Nanicão', possui altura que varia entre 2,0 e 3,0 m. O cacho apresenta-se ligeiramente cônico, pesando de 31 a $40 \mathrm{~kg}$, com 9-11 pencas e com 12-31 dedos cada uma. O número total de frutos por cacho está entre 145197, possuem ápices arredondados, pedicelos curtos e a polpa quando madura tem sabor idêntico ao da banana 'Nanica'. É suscetível às Sigatokas amarela e negra, aos nematóides (principalmente Radopholus similis) e à Broca-do-rizoma, sendo todavia, resistente ao Maldo-Panamá (CORDEIRO, 2003). 
'Nam', também conhecida como Prata Baby, é um cultivar triplóide do grupo AAA, introduzido da Tailândia, de porte médio a alto, resistente à Sigatoka-amarela e ao Mal-do-Panamá. Apresenta frutos pequenos, com polpa rósea e sabor doce. Depois de avaliada em diversos locais, foi recomendada para o Estado de Santa Catarina. Atualmente encontra-se em plantios comerciais e no mercado, atinge preço superior ao da 'Prata Anã' (SILVA et al., 2004).

Figo Cinza é um cultivar do grupo ABB, que apresenta porte variando entre 3,5 a 4,0 m. O cacho apresenta engaço longo, as pencas variam em número de 6 a 8 e os frutos são relativamente curtos. A casca é grossa, revestida de cera e o fruto apresenta polpa doce, macia, de cor creme-pálida e saborosa quando perfeitamente madura. Uma característica marcante do fruto é que estes permanecem com quinas salientes mesmo no ponto de colheita. Esse cultivar é resistente à seca, à Sigatoka-amarela, medianamente tolerante ao Mal-doPanamá e bem atacada pela broca. Tem sido utilizada em pequenas áreas, onde as chuvas são escassas (SILVA et al., 1999).

\subsection{Clima para a bananicultura}

No Brasil, a maioria das microrregiões homogêneas produtoras de banana se enquadram nos limites de 18 e $35^{\circ} \mathrm{C}$. Estes são níveis de temperatura essencialmente tropicais, porém há cultivos em microrregiões homogêneas subtropicais dos estados de São Paulo, Paraná, Santa Catarina, Rio Grande do Sul e Mato Grosso do Sul, onde os cultivares Branca e Enxerto, com melhor tolerância ao frio, são mais utilizados (MOREIRA, 1987; ALVES, 1990).

A bananeira adapta-se melhor à áreas livres de geadas severas com

altitudes pouco elevadas e terrenos bem drenados. Consideram-se ideais as regiões com temperatura média acima de $21^{\circ} \mathrm{C}$, com mínimas não inferiores a $15^{\circ} \mathrm{C}$, chuvas acima de 1300 mm anuais, médias mensais mínimas de $100 \mathrm{~mm}$ e umidade relativa do ar em torno de $80 \%$. A alta umidade acelera a emissão de folhas, favorece o lançamento e a coloração dos frutos (VIEIRA, 2004). Segundo Simão (1985) temperaturas abaixo de $12^{\circ} \mathrm{C}$ causam paralisação nas atividades da planta. 


\subsection{Adaptação dos cultivares em diferentes regiões}

Segundo Damatto Júnior et al. (2005), as bananeiras 'Prata Anã' e 'Prata Zulu' apresentaram um ciclo médio de 496 dias do plantio à colheita nas condições de Botucatu-SP. A bananeira 'Prata Zulu' apresentou cachos com peso muito superior $(33,97 \mathrm{Kg})$ a 'Prata Anã' $(17,70 \mathrm{Kg})$ e também superior aos dados relatados para este cultivar, que é de 20 a $25 \mathrm{Kg}$ por cacho. O 'Prata Zulu' produziu em média 215 frutos por cacho. O 'Prata Anã' produziu menor número de pencas por cacho (9,2 pencas), quando comparado com o 'Prata Zulu' (14 pencas). Na segunda penca, o número de frutos foi maior no 'Prata Zulu' (17 frutos) quando comparado ao 'Prata Anã' (15 frutos), bem como o peso da segunda penca foi superior para o 'Zulu'. A bananeira 'Prata Zulu' apresentou o dobro da produtividade $\left(54,35\right.$ t.ha $\left.^{-1}\right) \mathrm{em}$ comparação à 'Prata Anã' (28,32 t.ha' $\left.{ }^{-1}\right)$.

Leite et al. (2003) estudando acessos de bananeira em Belmont (BA) apresentaram dados diferentes em relação o 'Prata Anã', o qual apresentou no primeiro ciclo 451 dias, peso do cacho de $9 \mathrm{Kg} \mathrm{e} \mathrm{n}^{\mathrm{o}}$ de frutos/cacho:118. Segundo Leonel et al. (2004) o mesmo cultivar apresentou um ciclo de 434 dias, peso médio do cacho de 12,2 $\mathrm{Kg}$, produtividade média estimada de 19,5 t. ha $^{-1}$ e $\mathrm{n}^{\mathrm{o}}$ de frutos/cacho: 121, nas condições de Botucatu-SP. Com relação ao ciclo da cultura, em algumas regiões produtoras de bananas do Estado de Minas Gerais, Pereira et al. (1998) em Jaíba (região norte de Minas Gerais), e Salomão et al. (1998) em Visconde do Rio Branco (região da zona da mata de Minas Gerais), avaliando o comportamento do cv. Prata Anã em condições de sequeiro, relatam que o ciclo total foi, respectivamente, de 411 e 520 dias. O mesmo cultivar no oeste paulista apresentou o ciclo de 633 dias com irrigação e 646 dias em condições de sequeiro (FOLTRAN et al., 1998). Pereira et al. (1998), na mesma linha de pesquisa, obtiveram superioridade do cv. Prata anã em relação ao 'Prata' e 'Mysore', com maior peso do cacho e dos frutos, maior número de folhas funcionais, menores períodos vegetativo, produtivo e total. O peso médio dos frutos no primeiro ciclo foi de $115,62 \mathrm{~g}$ e do cacho foi de $11,61 \mathrm{Kg}$ na cv. Prata anã.

Brechbuelber \& Couto (1996) relataram que o cv. Nanicão apresentou menor ciclo entre o plantio e a colheita, bem como menor tempo entre a emissão do cacho e colheita. O número de frutos por cacho, o peso do cacho e das pencas foi maior no 'Nanicão', quando comparado com o 'Prata anã'. A produtividade estimada foi de 38 t.ha ${ }^{-1}$ no 'Nanicão' 
e 17 t.ha $^{-1}$ no 'Prata anã'. Leonel et al. (2004) estudando diferentes cultivares em Botucatu-SP, revelaram que o cv. Nanicão foi a mais precoce, com duração média total do primeiro ciclo de 416 dias e com peso do cacho de $19,06 \mathrm{Kg}$. A produtividade média estimada foi de 30,56 t. ha ${ }^{-}$

1. Gaiva (1992), estudando o comportamento das plantas-matrizes de bananeira, cultivares Farta-velhaco (grupo AAB), Mysore (AAB) e Nanicão (AAA), observou que o maior número de folhas ativas, na época da colheita, correspondeu a cachos mais pesados nos cvs. Mysore e Nanicão. No oeste paulista, Foltran et al. (1998) relataram produtividades médias no primeiro ciclo, com e sem irrigação, variando entre 8,9 e 16,9 t.ha ${ }^{-1}$ nas bananeiras 'Nanicão', 'Nanicão jangada', 'Mysore' e 'Grand naine'.

Leite et al. (2003) avaliando os genótipos 'Thap Maeo', 'Caipira' e 'Maça' observaram ciclo de 476, 451 e 480 dias, respectivamente. Em relação ao peso do cacho e $\mathrm{n}^{\mathrm{o}}$ de frutos/cacho o cultivar Thap Maeo apresentou $16 \mathrm{Kg}$ e 160 frutos, o Caipira 10 $\mathrm{Kg}$ e 92 frutos e o Maçã $10 \mathrm{Kg}$ e 86 frutos. Donato et al. (2003) observaram em Guanambi (BA) que os cvs. Caipira e Fhia 18 apresentaram dados semelhantes, com cacho pesando 15 $\mathrm{Kg}, 158$ frutos/cacho e ciclo de 359 dias. Silva et al. (2002) estudando vários híbridos e cultivares no município de Cruz das Almas (BA) relataram que os cvs. Thap Maeo, Fhia 18 e Caipira apresentaram no primeiro ciclo 391, 337 e 385 dias, respectivamente. O 'Thap Maeo’ e o 'Fhia 18 ' produziram um cacho de $13 \mathrm{Kg}$, enquanto que o do 'Caipira' foi de $9 \mathrm{Kg}$; em relação ao $\mathrm{n}^{\mathrm{o}}$ de frutos/cacho o 'Thap Maeo' apresentou 149 frutos, o 'Fhia 18': 134 e o 'Caipira': 108 frutos.

\subsection{Qualidade dos frutos de bananeira}

A maioria das variedades de bananeira cultivadas pelos produtores brasileiros apresenta baixo potencial produtivo e/ou alta suscetibilidade às principais doenças e pragas, o que, em alguns casos, tem limitado o seu cultivo extensivo. Estes problemas levaram a Embrapa Mandioca e Fruticultura a formar um banco de germoplasma de Musa spp. e na execução de um programa de melhoramento genético (SILVA, 2000). Entretanto, a adoção de novos híbridos de bananeira não se estabelece apenas pela sua resistência às enfermidades e conveniência agronômica. As características pós-colheita têm um papel significativo na aceitabilidade destes híbridos (DADZIE ; ORCHARD, 1997). 
Segundo Matsuura et al. (2004), a escolha da variedade pelo produtor é conseqüência entre outros fatores de alguns atributos de qualidade dos frutos destas variedades, tais como: sabor, vida útil e aparência. Os cultivares considerados resistentes, possuem toda uma caracterização agronômica, mas as informações sobre as características físico-químicas de seus frutos são muito incipientes.

A banana é um componente constante na dieta dos brasileiros, inclusive os de baixa renda, devido às suas características sensoriais e ao seu alto valor nutritivo. Apenas um fruto de banana pode suprir cerca de $25 \%$ da ingestão diária recomendada de ácido ascórbico, além de fornecer quantidades significativas de vitaminas A e B, potássio e outros minerais, como o sódio (DANTAS ; SOARES FILHO, 1995).

Dentre os parâmetros químicos mais utilizados para avaliar a qualidade pós-colheita da banana estão o pH, acidez titulável, sólidos solúveis, relação entre sólidos solúveis e acidez ou índice de maturação (IM) ou "ratio", açúcares redutores, açúcares nãoredutores, açúcares totais, substâncias pécticas e teor de amido (CHITARRA \& CHITARRA, 1990).

Segundo Palmer (1971), durante o amadurecimento, aumenta de $20 \mathrm{mg}$ kg-1 h-1 para cerca de $125 \mathrm{mg} \mathrm{kg}^{-1} \mathrm{~h}^{-1}$. Nessa fase, ocorre um aumento no teor de açúcares simples, de ácidos simples e orgânicos (predominando o ácido málico) e diminuição dos compostos fenólicos, de menor peso molecular, resultando na redução da adstringência e aumento da acidez, além da liberação de compostos voláteis, fatores responsáveis pelo aroma e sabor, que são características fundamentais para a aceitação da fruta (SOTO BALLESTERO, 1992). De acordo com Kieber (2004), dependendo da variedade do fruto, os conteúdos de ácidos cítricos e málico podem ou não diminuir durante o processo de amadurecimento.

A conversão do amido em açúcares simples é uma das mudanças mais notáveis no amadurecimento da banana. Esse é transformado, predominantemente, em açúcares redutores, glicose e frutose (8 a 10\%), e sacarose (10 a 20\%). Na fase madura, a porcentagem de amido é reduzida de 0,5 a 2,0 \%, dos $20 \%$, quando o fruto se apresenta verde.

Segundo Borges e Oliveira (2000), o potássio é o macronutriente extraído em maior quantidade pela bananeira. Este nutriente é de grande importância na produção de cachos e pencas, na qualidade e resistência dos frutos. 
As características internas percebidas pelo sabor, aroma e textura ao paladar, combinadas com a aparência do produto, são importantes na determinação da aceitação pelo consumidor (CHITARRA, 2000). E para determinar a aceitabilidade do consumidor por determinado produto, faz-se a análise sensorial. Tal análise é realizada mediante a utilização dos sentidos humanos: visão, gustação, olfato e sensibilidade-cutânea. Portanto, as sensações que resultam da interação dos órgãos humanos dos sentidos com os alimentos são usadas para avaliar sua qualidade, aceitabilidade por parte dos consumidores e nas pesquisas que visam o desenvolvimento de novos produtos (TEIXEIRA et al., 1987; MORAES, 1988). 


\section{MATERIAL E MÉTODOS}

\subsection{Localização do experimento}

O experimento foi conduzido no pomar experimental do Departamento de Produção Vegetal - Horticultura da Faculdade de Ciências Agronômicas - UNESP, Campus de Botucatu/SP, que apresenta as coordenadas geográficas: $22^{\circ} 55^{\prime} 55^{\prime \prime} \mathrm{S}, 48^{\circ} 26^{\prime}$ 22" O e altitude $810 \mathrm{~m}$. O tipo climático predominante no local é o temperado quente (mesotérmico) com chuvas no verão e seca no inverno (Cwa - Koppen), tendo temperatura média anual de $20,5^{\circ} \mathrm{C}$ e precipitação pluviométrica média anual de $1533 \mathrm{~mm}$ (CUNHA et al., 1999). O solo da área foi classificado como Nitossolo Vermelho, segundo os critérios da Embrapa (2006).

\subsection{Coleta de dados metereológicos}

Os dados de precipitação pluviométrica e temperaturas médias, máximas e mínimas mensais foram fornecidos pelo Posto Meteorológico do Departamento de Recursos Naturais da Faculdade e estão apresentados na Tabela 01. 
Tabela 01. Médias mensais das temperaturas máxima, mínima e média $\left({ }^{0} \mathrm{C}\right)$ e precipitações pluviométricas $(\mathrm{mm})$ de 2008 e 2009. Fonte: Departamento de Recursos Naturais FCA/UNESP, Botucatu/SP.

\begin{tabular}{|c|c|c|c|c|}
\hline Mês & $\begin{array}{l}\text { Temperatura } \\
\text { Mínima }\left({ }^{\circ} \mathrm{C}\right)\end{array}$ & $\begin{array}{l}\text { Temperatura } \\
\text { Máxima }\left({ }^{\circ} \mathrm{C}\right)\end{array}$ & $\begin{array}{l}\text { Temperatura } \\
\text { Média }\left({ }^{\circ} \mathrm{C}\right)\end{array}$ & $\begin{array}{c}\text { Precipitação } \\
\text { Pluviométrica } \\
\text { (mm) }\end{array}$ \\
\hline Janeiro & 18,2 & 28 & 23,1 & 102,3 \\
\hline Fevereiro & 18,7 & 27 & 22,85 & 100 \\
\hline Março & 18,57 & 27,5 & 23,03 & 60,9 \\
\hline Abril & 17,39 & 25,79 & 21,59 & 102,8 \\
\hline Maio & 13,85 & 22,79 & 18,32 & 115,7 \\
\hline Junho & 13,47 & 24,46 & 17,61 & 30,8 \\
\hline Julho & 13,85 & 24,61 & 19,13 & 0 \\
\hline Agosto & 15,07 & 25,54 & 20,31 & 104,1 \\
\hline Setembro & 15,12 & 25,48 & 20,3 & 29,9 \\
\hline Outubro & 18,27 & 26,76 & 22,47 & 153,8 \\
\hline Novembro & 16,66 & 27,35 & 22 & 69,3 \\
\hline Dezembro & 17,05 & 28,31 & 22,68 & 137 \\
\hline Média/2008 & 16,35 & 26,13 & 21,12 & 83,88 \\
\hline Janeiro & 18,22 & 26,61 & 22,42 & 135,2 \\
\hline Fevereiro & 19,51 & 28,38 & 23,94 & 151 \\
\hline Março & 19,24 & 28,85 & 24,4 & 211,8 \\
\hline Abril & 16,53 & 26,65 & 21,59 & 267,1 \\
\hline Maio & 14,99 & 24,91 & 19,95 & 248,7 \\
\hline Junho & 11,27 & 20,85 & 16,06 & 102,7 \\
\hline Julho & 12,99 & 22,56 & 17,77 & 143,8 \\
\hline Agosto & 13,68 & 24,13 & 18,90 & 89,1 \\
\hline Setembro & 15,76 & 25,53 & 20,645 & 150,5 \\
\hline Outubro & 15,14 & 26,74 & 20,94 & 141,8 \\
\hline Novembro & 19,75 & 29,51 & 24,63 & 289 \\
\hline Dezembro & 19,06 & 26,93 & 22,93 & 327,1 \\
\hline Média/2009 & 16,34 & 25,97 & 21,18 & 188,15 \\
\hline
\end{tabular}




\subsection{Tipos de mudas}

As mudas foram produzidas pelo processo de micropropagação e aclimatizadas em estufa possuindo certificação de sanidade vegetal, estando livres de pragas e doenças. As mudas, oriundas da empresa Banatech (SP), apresentavam altura da parte aérea entre 10 e $15 \mathrm{~cm}$ e torrão de $6 \mathrm{~cm}$, sendo transplantadas para sacolas de polietileno preto de 18,5 x 10,0 cm, preenchidas com mistura de terra e esterco de curral na proporção de 2:1. As plantas permaneceram durante 90 dias em estufa e após este período, foram transplantadas para o campo, em área previamente preparada.

\subsection{Implantação da área experimental}

O experimento foi conduzido em um bananal com dois anos de implantação. O plantio foi realizado no mês de janeiro/2006, adotando-se o espaçamento de $2,5 \mathrm{~m} \times 2,5 \mathrm{~m}$, com uma área de $6,25 \mathrm{~m}^{2} /$ planta, onde as covas foram abertas com dimensões de $60 \mathrm{~cm}$ de diâmetro por $60 \mathrm{~cm}$ de profundidade. Foram realizadas adubações orgânica e mineral nas covas de plantio e foram feitas adubações de cobertura aos 30, 60, 90 e 120 dias após o plantio, conforme as recomendações técnicas para a cultura (TEIXEIRA et al., 1997). Antes das adubações foi realizada a amostragem de solo da área, onde foram coletadas amostras no local de aplicação de adubo e entre as linhas na profundidade de 0-20 cm. Os resultados estão apresentados na Tabela 02. A dosagem dos adubos foi feita conforme RAIJ \& QUAGGIO (1983). 


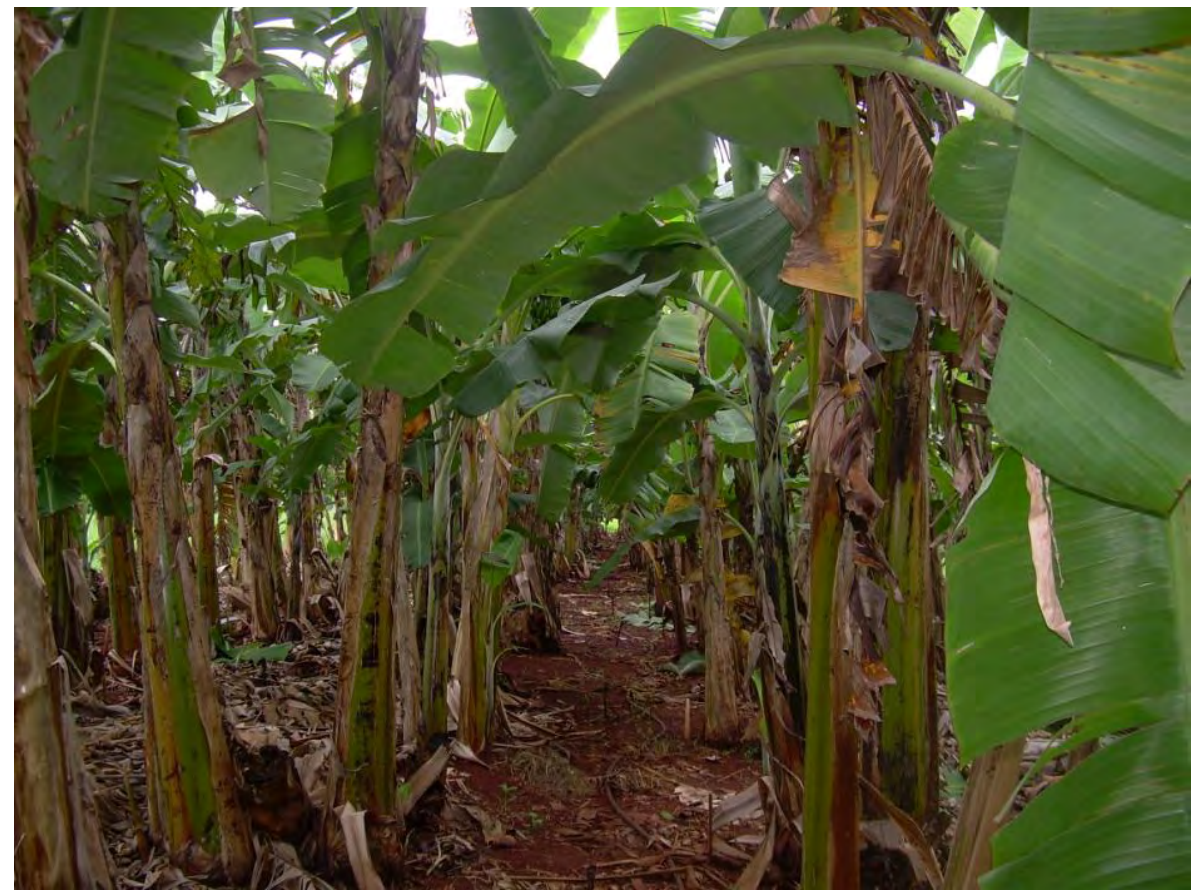

Figura 01 -. Bananal onde foi realizado o experimento - Botucatu-SP/ 2009. 
Tabela 02. Análise química do solo da área experimental referente a fevereiro de 2008 e fevereiro de 2009 - FCA/UNESP/ Botucatu-SP.

Fevereiro de 2008

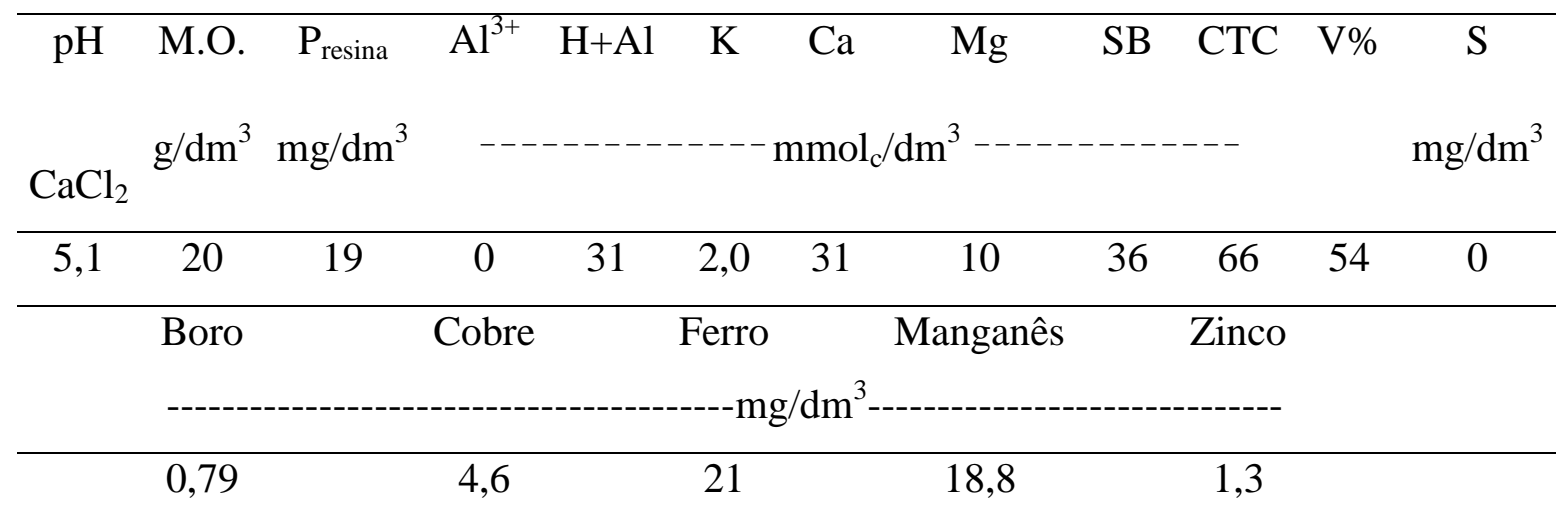

Fevereiro de 2009

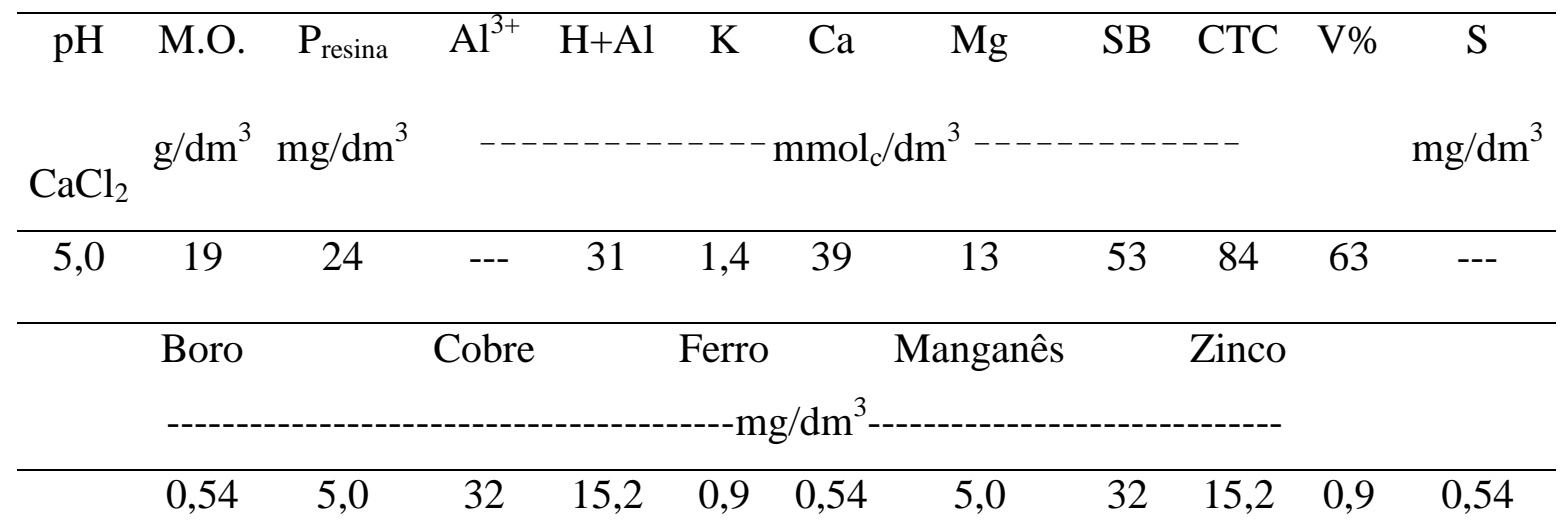

Fonte: Laboratório de Fertilidade do Solo. DCS-FCAIUNESP.

\subsection{Tratamentos}

Os tratamentos corresponderam aos diferentes genótipos de bananeira: 'Grand Naine', 'Nanicão-IAC', 'Nam', 'Caipira', 'Thap Maeo', 'Prata Anã', 'Prata Zulu', 'Fhia 01', 'Fhia 18', 'Prata Graúda', 'Maçã Tropical' e 'Figo Cinza', conforme apresentados nas figuras 02 a 05. 


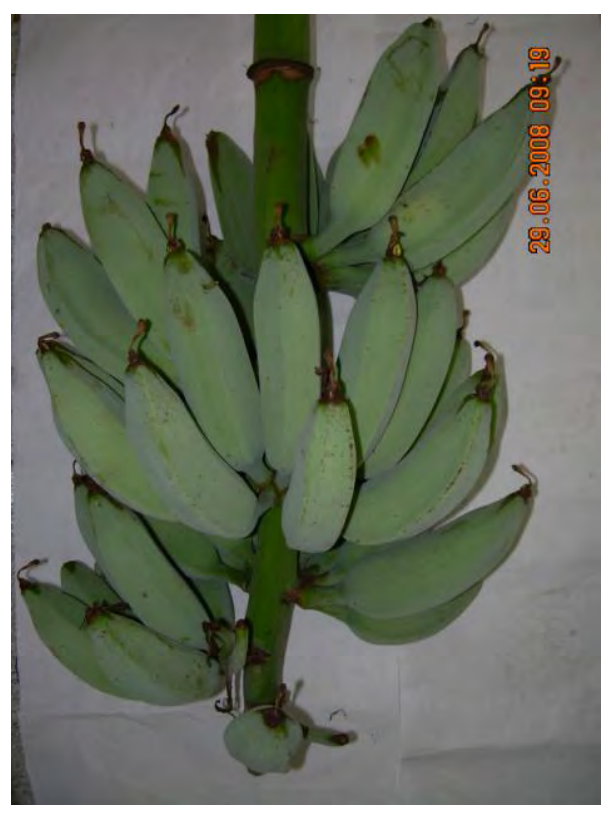

Figo Cinza

Figura 02 - Cacho do cultivar de bananeira 'Figo Cinza' do grupo genômico ABB, BotucatuSP/2009. 


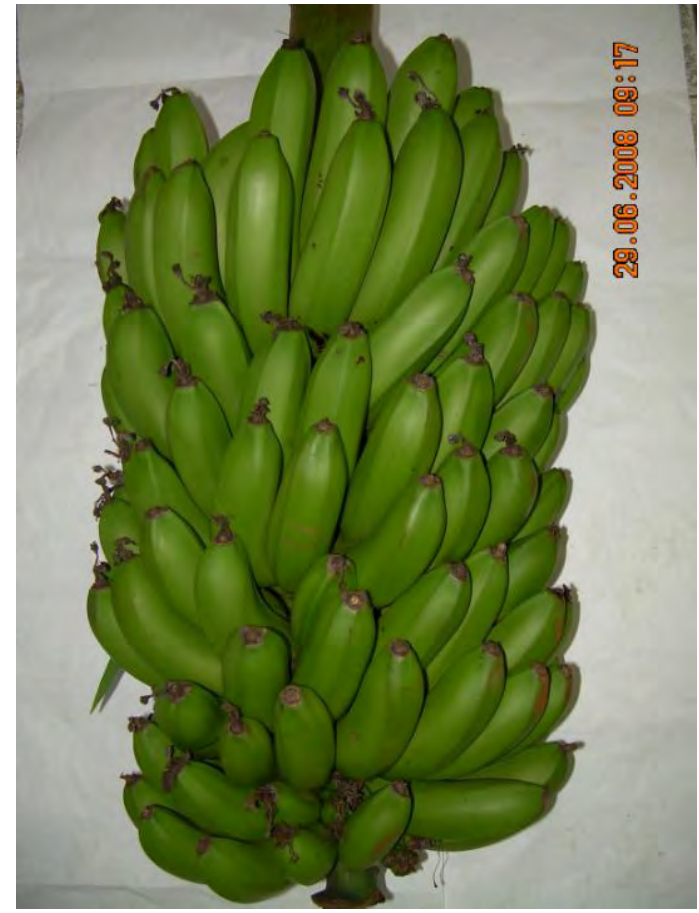

Nanicão

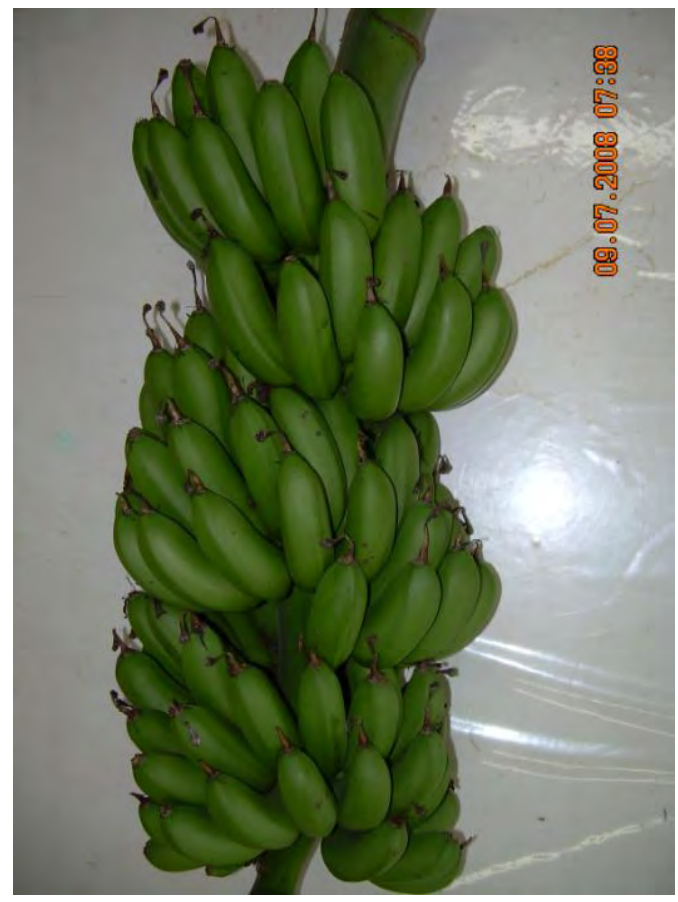

Nam

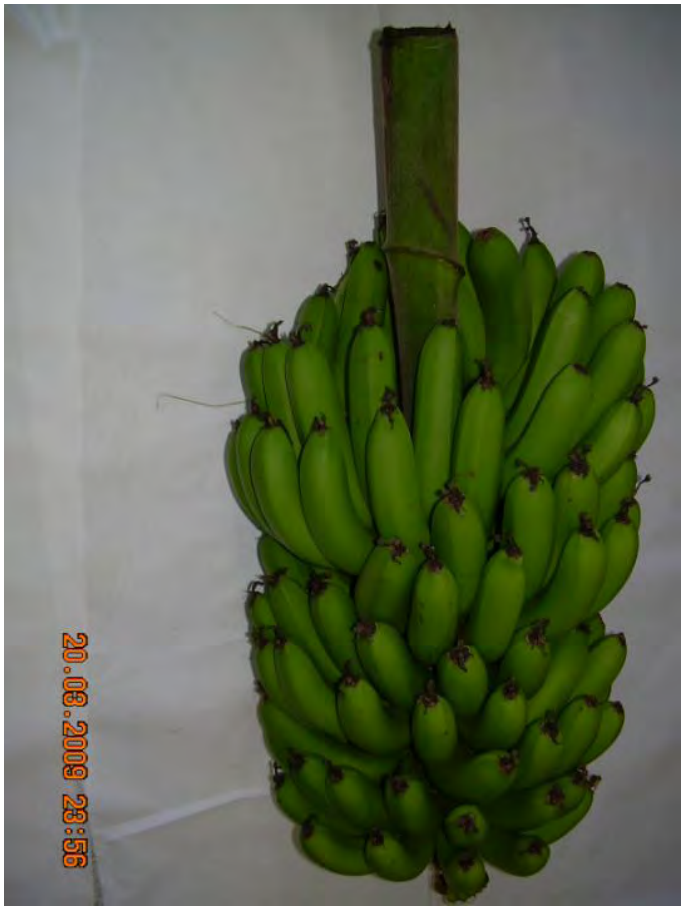

Grand Naine

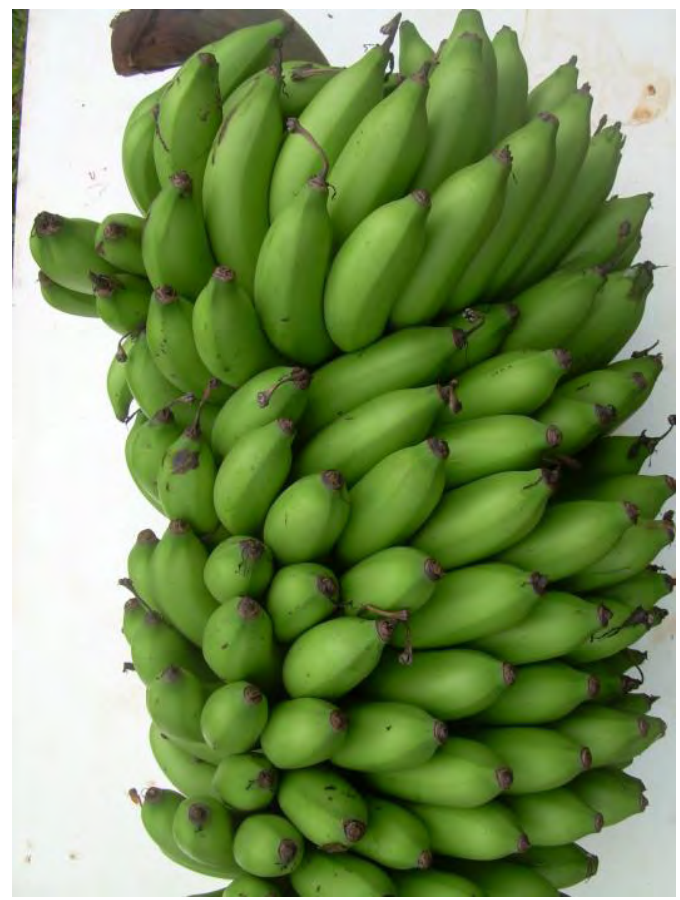

Caipira

Figura 03 - Cachos de cultivares de bananeira do grupo genômico AAA, Botucatu-SP/2009. 


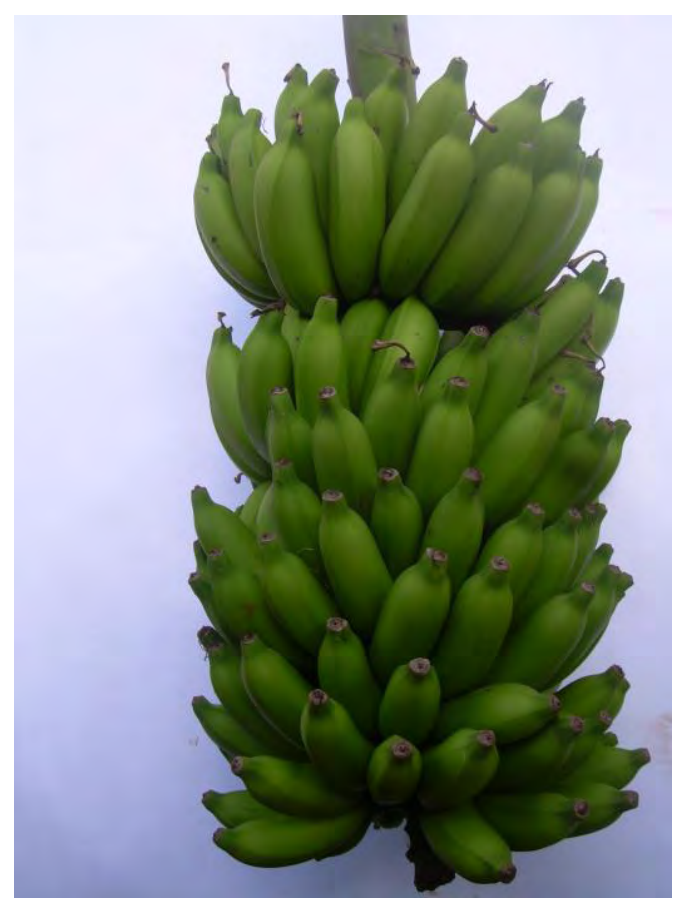

Thap Maeo

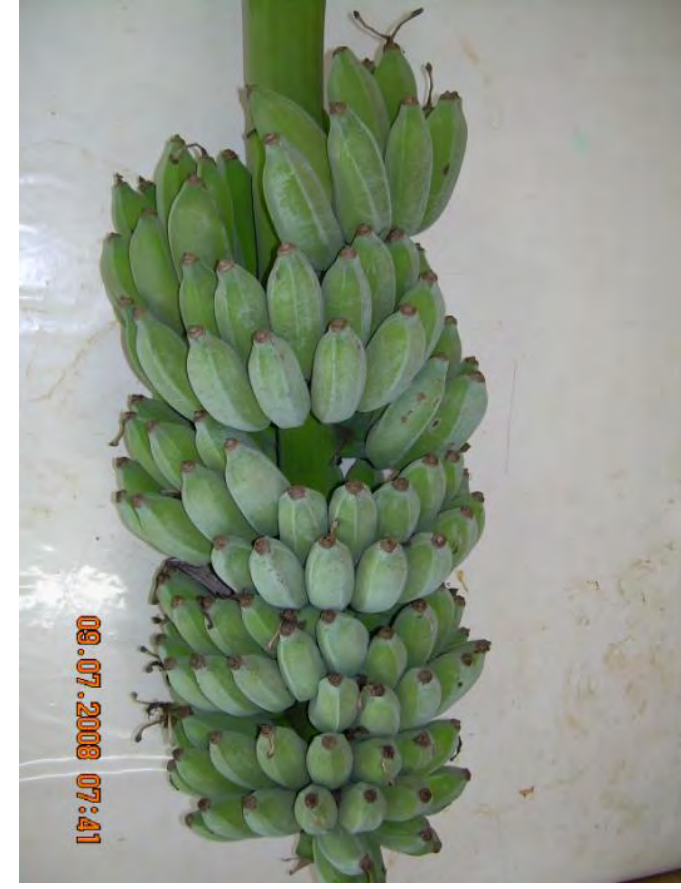

Prata Zulu

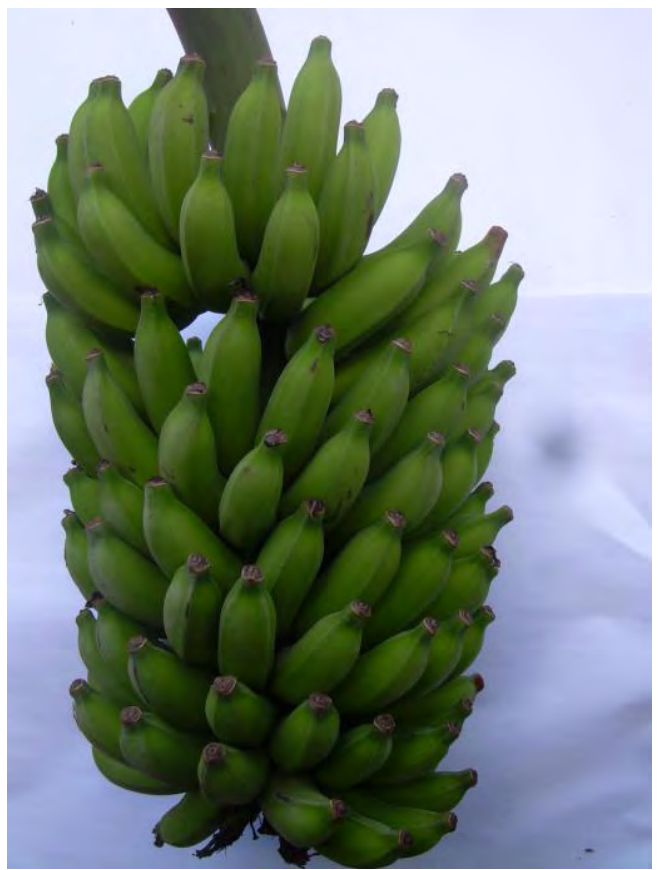

Prata Anã

Figura 04 - Cachos de cultivares de bananeira do grupo genômico AAB, Botucatu-SP/2009. 


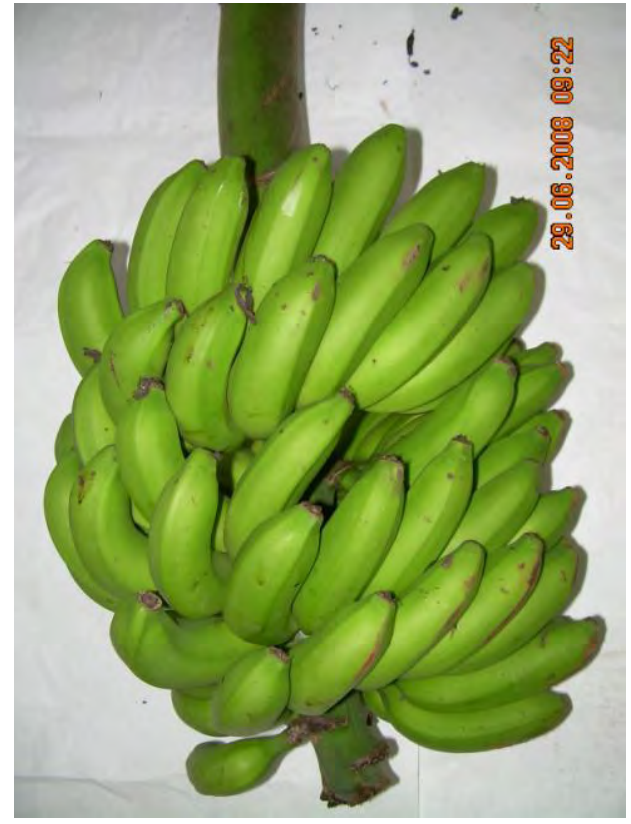

Maçã Tropical

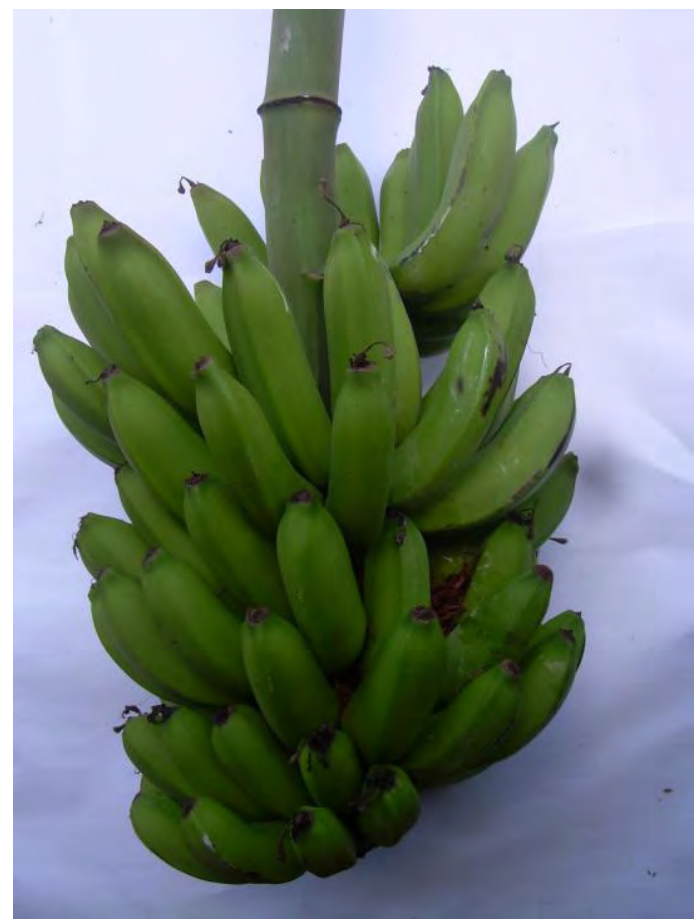

Prata Graúda

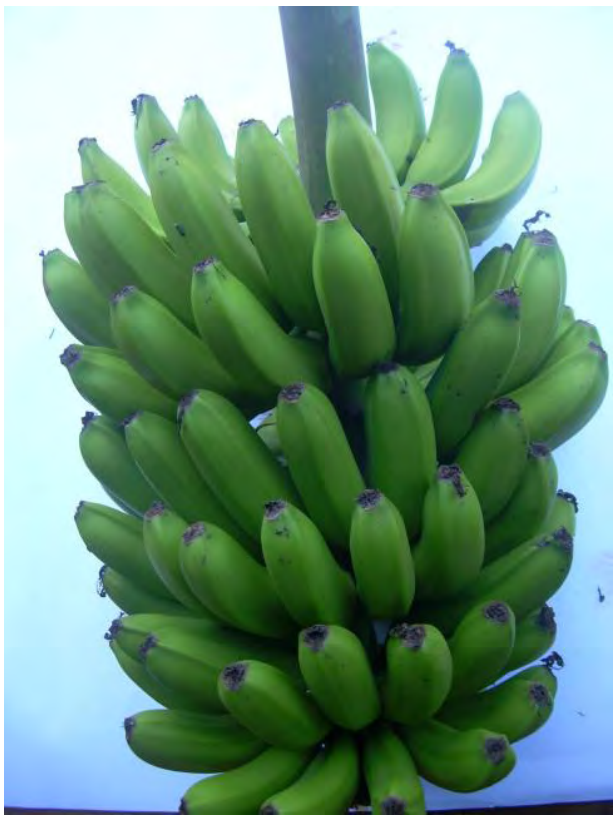

Fhia 18

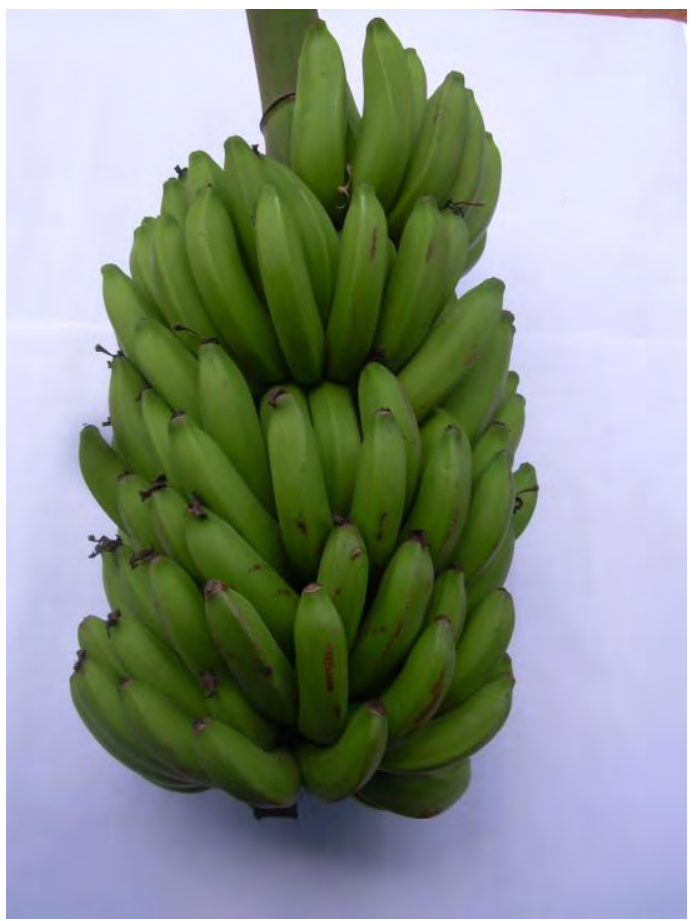

Fhia 01

Figura 05 - Cachos de híbridos de bananeira do grupo genômico AAAB, Botucatu-SP/2009. 


\subsection{Manejo da área}

\subsubsection{Adubação de produção}

As adubações foram parceladas em 6 vezes com produtividade esperada de 20-30 $\mathrm{t} \mathrm{ha}^{-1}$ (RAIJ et al., 1997). O adubo foi aplicado a cada 2 meses nas doses de $22 \mathrm{~g}$ de 8:28:16 + $32 \mathrm{~g}$ de cloreto de potássio + $45 \mathrm{~g}$ de uréia. Não foi aplicado micronutrientes, pois de acordo com a análise química do solo, estes elementos estavam em teores adequados às necessidades da cultura.

\subsubsection{Irrigação}

O suprimento de água para o experimento foi obtido de uma fonte natural, situada dentro do Campus da UNESP, bombeada e armazenada num reservatório com capacidade de $150 \mathrm{~m}^{3}$, situado em cota superior ao experimento, o que permitiu o funcionamento do sistema por gravidade.

O sistema de irrigação utilizado no experimento foi $\mathrm{o}$ de microaspersão, sendo os microaspersores autocompensantes com vazão de $35 \mathrm{~L} / \mathrm{h}^{-1}$ e diâmetro molhado de $4 \mathrm{~m}$. As linhas de irrigação foram instaladas entre as linhas de plantas e se constituíam de tubos de polietileno de $1 / 2$ ", onde se instalaram os microaspersores espaçados de $5 \mathrm{~m}$. O manejo foi feito com base na evaporação obtida no Tanque Classe "A" (ETA), sendo a quantidade de água aplicada de modo a satisfazer $100 \%$ da evapotranspiração da cultura (Etc). As lâminas aplicadas foram determinadas semanalmente e após observado o déficit hídrico, determinava-se o tempo em que os microaspersores permaneceriam ligados.

\subsubsection{Controle de plantas daninhas}

Durante o experimento foi feito o controle de plantas daninhas sempre que necessário. Apesar do dossel das bananeiras promover um sombreamento e os restos das folhas formarem uma cobertura no solo, dificultando a emergência de plantas invasoras, nos meses de novembro a janeiro que compreende o período chuvoso e de intenso calor, houve a necessidade controlar as plantas daninhas, o que foi feito através da capina manual. 


\subsubsection{Controle de Pragas e Doenças}

Para o controle da Sigatoka-amarela, em janeiro e fevereiro de 2008 e 2009 foi aplicado Tebuconazole ( FOLICUR 200 CE - 0,5 L/ha) + óleo mineral. Em março de 2008 e 2009, foram feitas iscas tipo telha (100 iscas/ha) no que foi observado o aparecimento da broca-do-rizoma da bananeira. Para o controle foi utilizado $5 \mathrm{~g}$ de Furadan (Carbofuran) por isca. As iscas foram trocadas a cada 2 semanas, e o procedimento foi repetido até a diminuição do número insetos por isca.

\subsubsection{Retirada de folhas secas}

As folhas secas foram retiradas quinzenalmente e colocadas nas entrelinhas, visando contribuir com as propriedades físicas e químicas do solo, bem como para facilitar o controle das plantas daninhas.

\subsubsection{Desbaste de perfilhos}

O primeiro desbaste foi feito em março de 2008 e o procedimento foi repetido a cada 3 meses utilizando uma ferramenta denominada "lurdinha", desenvolvida pelo Instituto Agronômico do Estado de São Paulo. No momento do desbaste foram deixadas 3 plantas por touceira, compondo assim o sistema de condução tradicional, planta "mãe", "filho" e "neto".

\subsubsection{Retirada do coração}

A retirada do coração foi feita quando este distanciava $10-12 \mathrm{~cm}$ da útima penca. Esta operação foi realizada para acelerar o desenvolvimento dos frutos, aumentar o peso e diminuir a incidência de tripes (Tryphactothrips lineatus) e traça-da-bananeira (Opogona sacchari) (RANGEL et al., 2002).

\subsubsection{Colheita}

A colheita foi feita por duas pessoas, sendo que uma cortava o pseudocaule e a outra recebia o cacho sobre o ombro. A colheita foi realizada no período da manhã, sendo o cacho colhido quando os frutos estavam verdes, de acordo com a classificação 
da CEAGESP (1998), no estádio de maturação equivalente a “ 3/4 gordo” (36-38mm) de diâmetro.

\subsection{Características avaliadas}

\subsubsection{Características de crescimento e duração do ciclo}

Foram avaliadas características de crescimento, tais como altura da planta, circunferência do pseudocaule e número de folhas ativas, essas medidas foram feitas na ocasião da emissão da inflorescência.

- Altura das plantas: foi medida com régua graduada da roseta foliar até o nível do solo e os resultados foram expressos em metros (m).

- Circunferência do pseudocaule: feita a uma altura de $30 \mathrm{~cm}$ do solo com fita métrica e os resultados expressos em centímetros $(\mathrm{cm})$.

- Número de folhas ativas: a contagem do número de folhas ativas foi feita considerando apenas as folhas com mais de 50\% de área verde.

- Número de dias do florescimento à colheita: foi contado o número de dias entre o lançamento da inflorescência e a colheita do cacho.

\subsubsection{Características de produção}

Após a colheita, os frutos foram levados para o laboratório de Fruticultura no Departamento de Produção Vegetal da FCA/UNESP, onde avaliaram-se as características de produção, tais como: peso dos frutos, do engaço e do cacho $(\mathrm{Kg})$, número de frutos por cacho, peso médio do fruto $(\mathrm{g})$, número de pencas e produtividade estimada $\left(\mathrm{t} \mathrm{ha}^{-1}\right)$. Da segunda penca foi avaliado o peso $(\mathrm{Kg})$, número, comprimento $(\mathrm{cm})$ e diâmetro $(\mathrm{mm})$ dos frutos.

- Peso médio do fruto: calculado através do quociente entre o peso dos frutos (sem o engaço) e o número de frutos.

- Produtividade: calculada considerando o peso médio dos frutos (sem o engaço) e um estande de 1600 plantas por hectare. 
- Comprimento dos frutos: foram medidas as distâncias entre as extremidades de 5 frutos centrais da $2^{\mathrm{a}}$ penca com auxílio de régua graduada. Os resultados expressos em $\mathrm{cm}$.

- Diâmetro dos frutos: com o auxílio de um paquímetro digital, o diâmetro foi medido na região central de 5 frutos da $2^{\mathrm{a}}$ penca e os resultados expressos em $\mathrm{mm}$.

\subsubsection{Características de qualidade dos frutos}

As análises químicas e físicas dos frutos foram realizadas no laboratório do Departamento de Gestão e Tecnologia Agroindustrial da FCA-UNESP. As análises foram feitas no mesmo dia da colheita e utilizou-se 5 frutos da segunda penca.

As análises realizadas no laboratório foram:

- Textura: obtida através da medida feita em dois pontos diferentes no fruto com casca, foi utilizado um texturômetro Stevens - LFRA Texture Analyser, com ponta de prova TA 9/1000. A velocidade de penetração da ponta foi de $2 \mathrm{~mm} \mathrm{~s}^{-1}$. Os resultados foram expressos em Newton $(\mathrm{N})$.

- pH: foi mensurado no extrato de frutos homogeneizados, onde utilizou-se o potenciômetro da marca Digimed DMPH-2, conforme a recomendação do Instituto Adolfo Lutz (1985).

- Acidez titulável (AT): foram utilizados 5 gramas de polpa homogeneizada e diluída em $95 \mathrm{~mL}$ de água deionizada. A titulação foi realizada com solução padronizada de hidróxido de sódio a $0,1 \mathrm{~N}$ e o indicador usado foi a fenolftaleína (I.A.L, 1985). Os resultados foram expressos em porcentagem de ácido málico.

- Sólidos Solúveis (SS): após a trituração dos frutos, a amostra foi filtrada em gase, retirou-se uma alíquota e em seguida fez-se a leitura dos sólidos solúveis por refratometria direta, através do refratômetro tipo ABBE, marca ATAGO - N1, conforme recomendações feitas pela A.O.A.C (1970). Os resultados foram expressos em graus Brix.

- Amido e açúcares totais: a metologia utilizada foi descrita por Somogy e adaptada por Nelson (1944). O aparelho utilizado foi o espectrofotômetro Micronal B 382, sendo a leitura realizada a $535 \eta \mathrm{m}$ e os resultados expressos em porcentagem. 
- Teor de potássio: Os frutos foram secos em estufa de circulação forçada de ar a uma temperatura de $65{ }^{\circ} \mathrm{C}$ até atingirem temperatura constante e em seguida foram moídos. O teor de potássio foi determinado de acordo com a metodologia preconizada por Malavolta et al. (1997). Os resultados foram transformados para a base seca e expressos em gramas por kilogragrama $\left(\mathrm{g} \mathrm{kg}^{-1}\right)$.

- Análise sensorial: para a realização da análise sensorial foi utilizado um cacho de cada genótipo, colhido no estádio de desenvolvimento equivalente a “3/4 gordo". Cinco pencas de cada cacho foram escolhidas ao acaso, evitando-se as pencas das extremidades do cacho. Os frutos foram analisados no ponto adequado de consumo, isto é, quando não apresentavam mais sabor adstringente. Para isso pedaços dos frutos foram experimentados diariamente e também, antes de cada análise sensorial. Antes de servir as amostras aos provadores, foi feita uma caracterização físico-química dos frutos, onde determinou-se textura dos frutos sem casca, pH, sólidos solúveis (SS), e acidez titulável (AT).

$\mathrm{Na}$ análise sensorial avaliou-se a aceitação dos atributos aroma, sabor, textura, aparência e depois foi feita ainda uma avaliação global da amostra. Para tal análise foi usado a escala hedônica de 9 pontos, com extremidades denominadas: desgostei muitíssimo (1) e gostei muitíssimo (9) (MORAES, 1988). A cada análise, frutos de 3 acessos foram servidos na quantidade de 1 rodela de cada por provador, cuja espessura era de $1,5 \mathrm{~cm}$ (evitando-se as extremidades dos dedos). Os testes foram feitos por 50 provadores não treinados.

A autorização concedida pelo Comitê de Ética da UNESP/Faculdade de Medicina de Botucatu-SP para realização da análise sensorial e o modelo da ficha de avaliação utilizada na análise, estão apresentados nos apêndices I e II, respectivamente.

\subsection{Delineamento experimental}

Foi adotado o delineamento experimental inteiramente casualisado, com 12 tratamentos (acessos), 5 repetições e duas plantas úteis por parcela experimental, rodeadas por quatro plantas bordadura. Para as análises químicas e físicas foram utilizados 5 frutos em cada repetição. 
Foi feita análise de variância e quando houve diferença significativa, os dados foram comparados pelo teste de Tukey a 5\% de probabilidade. A comparação entre as médias foi realizada dentro de cada grupo genômico,. Os dados foram analisados pelo programa estatístico SAS. 


\section{RESULTADOS E DISCUSSÃO}

Os resultados estão apresentados por características de crescimento, duração de dias do florescimento a colheita, características de produção, características de qualidade dos frutos e análise sensorial dos frutos. Todas essas características foram avaliadas para os cultivares dentro de cada grupo genômico.

$\mathrm{Na}$ discussão dos resultados, as comparações feitas com outros trabalhos de pesquisa foram referentes em sua maioria, com o segundo ciclo de produção, pois os dados analisados neste trabalho são referentes ao segundo ciclo de produção.

\subsection{Características de crescimento}

\subsubsection{Altura de planta \\ Grupo AAA}

Os cultivares Grand Naine e Caipira não apresentaram diferenças entre si, onde foi observado altura de 3,04 e 3,20 m respectivamente (Tabela 03). Já os cultivares Nanicão e Nam apresentaram menor porte 2,40 e 2,70 m respectivamente, porém não diferiram entre si.

A altura de plantas é considerada um dos principais descritores sob o ponto de vista fitotécnico e de melhoramento, pois está ligada aos aspectos de densidade de 
plantio, produção e manejo da cultura (GONÇALVES et al., 2008). Todavia, em um cultivar comercial é indesejável que a bananeira expresse valores muito elevados, pois pode dificultar a colheita e provocar o tombamento da planta em decorrência de ventos fortes e ataque de nematóides e broca (LEDO et al., 1997). No melhoramento genético da cultura é importante selecionar genótipos de porte não muito elevado, exceto se tais genótipos apresentarem um potencial de produção e outras características agronômicas favoráveis.

Ramos et al. (2009b) em trabalho realizado no município de BotucatuSP, verificaram que os cultivares Grand Naine, Caipira, Nanicão e Nam apresentaram altura de 2,70, 2,20, 2,40 e 2,30 m, respectivamente. Leonel et al. (2004) também em Botucatu-SP, no primeiro ciclo de produção observaram uma altura de 2,10 m para o cultivar Nanicão. Entretanto, Lima et al. (2005) em Cruz das Alamas-BA registraram altura de 2,70 m para o cultivar Nanicão. Em Guanambi-BA, Donato et al. (2003) relataram que o cultivar Grand Naine atingiu uma altura de 2,43 m no segundo ciclo de avaliação. Ledo et al. (2008) avaliando o desempenho agronômico de 20 acessos de bananeira no município de Propriá-SE, constataram altura de 2,17 m para o cultivar Grand Naine e 3,25 m para 'Caipira' em um ciclo de avaliação.

Rodrigues et al. (2006) avaliaram diferentes acessos de bananeira em quatro ciclos de produção, e observaram que 'Caipira' apresentou uma variação de altura de 3,10 a 4,26 m do primeiro ao quarto ciclo. Em condições de sequeiro Pereira et al. (2003) verificaram para 'Caipira', 2,50 m e 'Nam' e 'Nanicão' apresentaram 2,30 m de altura.

Nota-se que a altura dos diferentes acessos variou com os diferentes locais em que foram cultivados, esta resposta se deve a variação climática de cada região.

\section{Grupo AAB}

Dos três cultivares avaliados neste grupo, Prata Anã apresentou menor porte $(3 \mathrm{~m}$ ) (Tabela 03). Entretanto, a maior altura foi observada para o cultivar Prata Zulu (3,68 m), não diferenciando do cultivar Thap Maeo que atingiu uma de 3,44 m.

Ramos et al. (2009b) trabalhando com diferentes acessos de bananeira em Botucatu-SP, observaram que o cultivar Prata Zulu apresentou maior porte $(3,0 \mathrm{~m})$ quando comparado com os cultivares Thap Maeo e Prata Anã que atingiram alturas de 2,50 e 2,10 m, respectivamente. Leonel et al. (2004) também em Botucatu-SP, observaram que o cultivar 
Prata Anã alcançou uma altura de 2,30 m. Nas mesmas condições, Gomes (2004) e Damatto Júnior et al. (2005) constataram uma altura para o cultivar Prata Anã correspondente a 2,10 e 2,60 m, respectivamente. Os valores de altura para 'Prata Anã' encontrados no presente trabalho são superiores aos relatados pelos autores citados acima. Porém, Damatto Júnior (2008) também trabalhando na mesma região com o cultivar Prata Anã relatou altura de 3,46 $\mathrm{m}$, a qual foi superior a do trabalho em questão. Tais diferenças podem ser atribuídas às diferenças climáticas ocorridas nos períodos de avaliação. 
Tabela 03.Valores médios de altura da planta, circunferência do pseudocaule, número de folhas por planta e número de dias do florescimento à colheita de acessos de bananeira, Botucatu/SP (março de2008 a maio 2009).

\begin{tabular}{|c|c|c|c|c|}
\hline \multicolumn{5}{|c|}{ GRUPO AAA } \\
\hline Cultivares & $\begin{array}{l}\text { Altura de Plantas } \\
\qquad(\mathrm{m})\end{array}$ & $\begin{array}{c}\text { Circunferência } \\
\text { do } \\
\text { Pseudocaule } \\
\text { (cm) }\end{array}$ & $\begin{array}{l}\text { Número de } \\
\text { folhas } \\
\text { por planta }\end{array}$ & $\begin{array}{c}\mathrm{N}^{\mathbf{o}} \text { de dias do } \\
\text { florescimento } \\
\text { a } \\
\text { colheita } \\
\end{array}$ \\
\hline Grand Naine & $3,04 \mathrm{~A}$ & $77,80 \quad \mathrm{~A}$ & $10,80 \mathrm{~A}$ & $154,00 \mathrm{~A}$ \\
\hline Nanicão & $2,40 \mathrm{~B}$ & $71,60 \mathrm{AB}$ & $10,68 \mathrm{~A}$ & $103,00 \mathrm{C}$ \\
\hline Caipira & $3,20 \mathrm{~A}$ & $68,00 \mathrm{~B}$ & $10,20 \quad \mathrm{~A}$ & $121,00 \mathrm{~B}$ \\
\hline Nam & $2,70 \mathrm{~B}$ & $64,60 \mathrm{~B}$ & $10,20 \quad \mathrm{~A}$ & $100,00 \mathrm{C}$ \\
\hline CV \% & 11,06 & 6,38 & 11,79 & 7,81 \\
\hline $\mathbf{F}$ & $6,49 *$ & $7,88 *$ & $0,33 \mathrm{~ns}$ & $37,59 *$ \\
\hline \multicolumn{5}{|c|}{ GRUPO AAB } \\
\hline \multicolumn{5}{|l|}{ Cultivares } \\
\hline Thap Maeo & $3,44 \mathrm{~A}$ & $71,60 \mathrm{~B}$ & $10,30 \mathrm{~A}$ & $96,00 \mathrm{~B}$ \\
\hline Prata Anã & $3,00 \mathrm{~B}$ & $81,60 \mathrm{AB}$ & $11,40 \mathrm{~A}$ & $152,00 \mathrm{~A}$ \\
\hline Prata Zulu & $3,68 \mathrm{~A}$ & $84,80 \mathrm{~A}$ & $12,20 \mathrm{~A}$ & $128,00 \mathrm{~A}$ \\
\hline CV \% & 6,40 & 7,83 & 13,35 & 15,83 \\
\hline $\mathbf{F}$ & $12,74 *$ & $6,14^{*}$ & $1,65 \mathrm{~ns}$ & $10,20 *$ \\
\hline \multicolumn{5}{|c|}{ GRUPO AAAB } \\
\hline \multicolumn{5}{|l|}{ Híbridos } \\
\hline Fhia 01 & $3,38 \mathrm{~A}$ & $101,80 \mathrm{~A}$ & $11,90 \mathrm{~A}$ & $146,60 \mathrm{~A}$ \\
\hline Prata Graúda & $3,48 \mathrm{~A}$ & $94,00 \mathrm{AB}$ & $10,40 \mathrm{~A}$ & $153,80 \mathrm{~A}$ \\
\hline Fhia 18 & $3,52 \mathrm{~A}$ & $93,40 \mathrm{AB}$ & $11,10 \mathrm{~A}$ & $163,40 \mathrm{~A}$ \\
\hline Maçã Tropical & $3,62 \mathrm{~A}$ & $88,60 \mathrm{~B}$ & $10,40 \mathrm{~A}$ & $90,00 \mathrm{~B}$ \\
\hline CV \% & 4,24 & 5,44 & 9,63 & 15,13 \\
\hline $\mathbf{F}$ & $2,24 \mathrm{~ns}$ & $5,61 *$ & $2,29 \mathrm{~ns}$ & $14,09 *$ \\
\hline \multicolumn{5}{|c|}{ GRUPO ABB } \\
\hline \multicolumn{5}{|l|}{ Cultivar } \\
\hline & 3,50 & 64,20 & 10,80 & 133,00 \\
\hline
\end{tabular}

Médias seguidas das mesmas letras na coluna não diferem entre si pelo teste de Tukey a 5\% de probabilidade 
Gonçalves et al. (2008) registraram em Janaúba-MG que o cultivar Thap Maeo teve altura de 2,86 m, já para o 'Prata Anã'os autores observaram altura de 2,55 m. Ledo et al.(2008) trabalhando com diferentes acessos de bananeira em Propriá-SE, constataram no segundo ciclo de produção alturas de 4,16 e 3,23 m para os cultivares Thap Maeo e Prata-anã respectivamente. Silva et al. (2002) observaram em Cruz das Almas-BA para 'Thap Maeo' uma altura de 2,70 m e para 'Prata Anã' 2,20 m. Em Rio Branco-AC, Ledo et al. (1997) relataram para 'Thap Maeo' uma altura de 2,90 m.

Ficou evidenciado em todos os trabalhos realizados que independente da região de cultivo, o cultivar Prata-Anã apresentou menor porte quando comparado aos cultivares Thap Maeo Prata Zulu, concordando com os dados deste trabalho.

\section{Grupo AAAB}

A altura dos híbridos pertencentes a esse grupo variou de 3,38 m para 'Fhia 01' e 3,62 m para 'Maçã Tropical', 'Prata Graúda' e 'Fhia 18' tiveram valores intermediários: 3,48 e 3,52 m respectivamente, entretanto não houve diferença significativa entre os híbridos.

Em Botucatu-SP, Ramos et al. (2009b) verificaram no primeiro ciclo de produção que o híbrido 'Maçã tropical' teve altura de 3,20 m, sendo superior aos híbridos 'Fhia 01', 'Prata Graúda' e 'Fhia 18', que atingiram respectivamente alturas de 2,60, 2,70 e 2,80 m. Ledo et al. (2008) avaliando dois ciclos de produção de diferentes acessos de bananeira em Propriá-SE, relataram que no primeiro ciclo o acesso 'Fhia 18' teve altura de 2,50 m. Entretanto, no segundo ciclo esse mesmo acesso alcançou altura de 3,46 m, valor que se aproxima do encontrado no presente trabalho.

Pereira et al. (2003) em Lavras-MG, observaram em condições de sequeiro que 'Fhia 18' apresentou altura de 2,70 m, os mesmos autores verificaram que 'Fhia 01' e 'Prata Graúda' tiveram altura de 2,60 m. Donato et al. (2003), em Guanambi-BA, relataram altura de 2,40 m para 'Fhia 18' e 'Fhia 01', sendo que para 'Prata Graúda' observaram altura de 2,20 m. Santos et al. (2006) em Jataí-GO, registraram altura de 2,0 m tanto para 'Fhia 18' como para 'Fhia 01 '. 
Em Cruz das Almas-BA, Lima et al. (2005) observaram que o híbrido 'Maçã Tropical', atingiu 2,90 m de altura. Para esse mesmo acesso, Saes et al. (2005) observaram alturas de 3,10 e 3,20 m respectivamente, indicando o porte elevado desse híbrido, quando comparado com os híbridos Fhia 01 e Fhia 18.

\section{Grupo ABB}

O cultivar Figo Cinza apresentou altura de 3,50 m (Tabela 03). Gonzaga Neto et al. (1993) encontraram resultados semelhantes em pesquisa realizada no Submédio São Francisco, relatando altura de 3,10 m para o mesmo cultivar. Ramos et al. (2009a) em Botucatu-SP notaram que esse cultivar teve uma altura de 2,90 m.

Segundo Saes et al. (2005), a altura do cultivar Figo Cinza pode variar de 3,50 a 4,0 m. Portanto, confirmam o valor encontrado nesse trabalho.

É importante considerar que a altura na bananeira é uma das características que se estabiliza a partir do segundo ciclo de cultivo. Além disso, as diferentes condições edafoclimáticas encontradas no Brasil podem interferir nessa característica.

\subsubsection{Circunferência do pseudocaule \\ Grupo AAA}

O cultivar Grand Naine apresentou maior circunferência $(77,80 \mathrm{~cm})$, todavia os menores valores de circunferência foram observados para os cultivares Caipira e Nam, 68,00 e 64,60 cm respectivamente, os quais não diferiram entre si. O cultivar Nanicão teve valor intermediário: 71,6 cm, não apresentando diferença em relação aos demais acessos do grupo.

A circunferência do pseudocaule é uma das características importantes na seleção de genótipos, pois está associada ao vigor da planta, a densidade do plantio e a capacidade de sustentação do cacho. Os genótipos que apresentam maior diâmetro são menos suscetíveis ao tombamento pelo vento (SILVA et al., 2002).

Os dados do presente trabalho são semelhantes aos valores encontrados por Ramos et al. (2009b) que relataram que o cultivar Grand Naine teve maior 
circunferência do pseudocaule $(76,70 \mathrm{~cm})$, enquanto que o 'Nanicão' atingiu $71,20 \mathrm{~cm}$ e os menores valores foram observados para 'Caipira' $(61,80 \mathrm{~cm})$ e 'Nam' $(63,20 \mathrm{~cm})$.

Leonel et al. (2004) em Botucatu-SP, relataram para o cultivar Nanicão uma circunferência de 71,80 cm. Em Rio Branco-AC, Ledo et al. (1997) observaram para 'Nam' 54,10 cm e 'Caipira' 45,70 cm. Donato et al. (2006a), em Guanambi-BA, encontraram para 'Grand Naine' 73,90 cm de circunferência e 72,10 cm para 'Nanicão'. Ledo et al. (2008), em Propriá-SE, avaliando diferentes acessos de bananeira verificaram que o cultivar Caipira apresentou circunferência de 77,17 cm, no entanto em Janaúba-MG, Gonçalves et al. (2008) constataram altura de $51,30 \mathrm{~cm}$ para esse mesmo cultivar.

É possível observar que em todos os trabalhos mencionados, independente da região, os cultivares Grand Naine e Nanicão apresentaram maior circunferência do pseudocaule, ao passo que a menor circunferência foi verificada para 'Caipira' e 'Nam'.

\section{Grupo AAB}

Os valores de circunferência do pseudocaule nesse grupo variaram de $71,60 \mathrm{~cm}$ no cultivar Thap Maeo a $84,80 \mathrm{~cm}$ para o 'Prata Zulu', o cultivar Prata Anã não diferiu dos demais, apresentando circunferência de $81,60 \mathrm{~cm}$.

Ramos et al. (2009b) avaliando o desempenho agronômico de acessos de bananeira em Botucatu-SP, observaram a mesma tendência para essa característica, onde o cultivar Prata Zulu teve circunferência de 80,10 cm, Prata Anã 67,70 cm e Thap Maeo 66,40 cm. Nas mesmas condições, Leonel et al. (2004) e Gomes (2004) registraram circunferência de 70,00 cm para 'Prata Anã'. Damatto Júnior et al. (2005) e Damato Júnior (2008) reportaram para esse mesmo cultivar, circunferência de 75,80 e 95,40 cm, respectivamente.

Ledo et al. (2008) em Propriá-SE, observaram que 'Prata Anã' teve circunferência de 87,50 cm e 'Thap Maeo' 88,92 cm. Todavia, em Janaúba-MG, Gonçalves et al. (2008), verificaram que o cultivar Prata Anã teve circunferência de 78,90 cm e 'Thap Meo' $64,70 \mathrm{~cm}$. Rodrigues et al. (2006), no Norte de Minas Gerais, um perímetro de 67,00 cm para 'Prata Anã' e Ledo et al. (1997), em Rio Branco-Acre, constataram que o cultivar 'Thap Maeo' teve circunferência de 70,50 cm. 


\section{Grupo AAAB}

'Fhia 01' diferiu dos outros híbridos, apresentando a maior circunferência do pseudocaule $(101,80 \mathrm{~cm})$ (Tabela 03). Não houve diferença entre 'Prata Graúda' e 'Fhia 18' que apresentaram, respectivamente 94 e 93,40 cm. Contudo, a menor circunferência foi constatada para 'Maçã Tropical' $(88,60 \mathrm{~cm})$.

Ledo et al. (2008), em Propriá-SE, observaram que o hibrido 'Fhia 18' teve diâmetro do pseudocaule igual a $81 \mathrm{~cm}$. Em Cruz das Almas-BA, Lima et al (2005), registraram diâmetro de 26,10 cm para 'Prata Graúda' e 26,18 cm para 'Maçã Tropical' correspondendo a circunferência de 81,90 e 82,23 cm respectivamente. Silva et al. (2002), em Petrolina-PE, encontraram para 'Maçã Tropical' circunferência de $76 \mathrm{~cm}$ e Rodrigues et al. (2006), perímetros de $98 \mathrm{~cm}$ para 'Prata Graúda', $92 \mathrm{~cm}$ para 'Fhia 01' e $85 \mathrm{~cm}$ para 'Fhia 18'.

\section{Grupo ABB}

O cultivar Figo Cinza apresentou circunferência de 64,20 cm (Tabela 03). Ramos et al. (2009a), em Botucatu-SP, verificaram para esse mesmo cultivar 59,80 cm no primeiro ciclo de produção, o que está coerente, pois os dados do segundo ciclo de produção costumam ser maiores que do primeiro.

\subsubsection{Número de folhas ativas \\ Grupo AAA}

O número de folhas ativas no florescimento também é considerado um descritor muito importante na avaliação de genótipos, pois as folhas constituem a parte essencial na geração de fotoassimilados por meio da taxa de fotossíntese da planta e que influencia diretamente nas características de crescimento e produção das variedades (ALVES, 1999). Gaiva (1992) observou que o maior número de folhas na colheita correspondeu a cachos mais pesados em alguns acessos.

Não houve diferença entre os cultivares para o número de folhas ativas na emissão da inflorescência. 'Grand Naine' apresentou 10,80 folhas, 'Nanicão' 10,68, 'Caipira' e 'Nam' apresentaram 10,20 folhas. 
Leonel et al. (2004), em Botucatu-SP, verificaram que para 'Nanicão' o número de folhas foi igual a 18. Em Cruz das Almas-BA, Lima et al. (2005), observaram para o cultivar 'Nanicão' 8,58 folhas no segundo ciclo de produção. Oliveira et al. (2007), em Viçosa-MG, avaliando as principais características de acessos de bananeira relataram um número de folhas para 'Grand Naine' igual a 10,60 e 11,50 folhas para 'Nam e Caipira'. Rodrigues et al. (2006), no Norte de Minas Gerais, observaram para 'Caipira' 13 folhas vivas na ocasião do florescimento, já Donato et al. (2006), em Guanambi-BA, relataram 16 folhas e para o cultivar 'Grand Naine' 15,72.

O número de folhas variou para cada região, possivelmente os lugares onde há maior incidência de Sigatoka Amarela e Sigatoka Negra o número de folhas tende a ser menor, principalmente em lugares úmidos e quentes, ambiente favorável a essas doenças. Além disso, pode haver diferenças nos tratos culturais.

\section{Grupo AAB}

Embora nesse grupo o cultivar Prata Zulu tenha apresentado maior número de folhas (12), não diferiu dos cultivares Prata Anã e Thap Maeo que mostraram 11,40 e 10,30 folhas, respectivamente (Tabela 03).

Ramos et al. (2009b), em Botucatu-SP, estudando os mesmos cultivares, também não observaram diferenças para o número de folhas, concordando portanto com os dados deste trabalho. Os autores relataram para 'Prata Zulu': 12,40 folhas, 'Prata Anã': 12,80 e para 'Thap Maeo': 11,20. Damato Júnior (2008), nas mesmas condições edafoclimáticas, observou para 'Prata Anã' um número de folhas igual a 10,10, valor semelhante ao encontrado no presente trabalho.

Em Propriá-SE, Ledo et al. (2008) verificaram para 'Prata Anã' e 'Thap Maeo' um número de folhas igual a 11,90 e 12,20, respectivamente. Rodrigues et al. (2006), no norte de Minas Gerais, observaram que o cultivar 'Prata Anã' apresentou 17 folhas. Entretanto, Donato et al. (2006), em Guanambi-BA, relataram para 'Prata Anã' 18,81 folhas. 


\section{Grupo AAAB}

Os híbridos apresentaram número semelhante de folhas, não diferindo entre si. Foi observado para 'Fhia 01'11,90 folhas, 'Prata Graúda' 11,40, 'Fhia 18' 11,10 e 'Maçã Tropical' 10,40 (Tabela 03).

Esses resultados estão próximos aos encontrados por Ramos et al. (2009b) que em Botucatu-SP, relataram para 'Fhia 01', 'Prata Graúda' e 'Fhia 18,' 12 folhas no florescimento e para 'Maçã Tropical' observaram 10 folhas. Em Viçosa-MG, Oliveira et al. (2007) encontraram um número de folhas para 'Fhia 01' igual a 10,90 e para 'Fhia 18' 10,60. Ledo et al (2008), em Propriá-SE, também encontraram resultado semelhante para 'Fhia 18' $(10,60)$. Donato et al. (2003) verificaram para 'Fhia 18' 12,80 folhas e para 'Fhia 01' 11,70.

\section{Grupo ABB}

Observa-se na Tabela 03 que o cultivar Figo Cinza apresentou 10,80 folhas no florescimento. Ramos et al. (2009a), em Botucatu-SP, observaram 13 folhas para o mesmo cultivar no primeiro ciclo de produção.

Soto Ballestero (1992) comenta que oito folhas na ocasião do florescimento é o suficiente para o desenvolvimento do cacho. Segundo Champion (1975), o número de folhas presentes no pseudocaule no momento da iniciação floral é regularmente constante, variando de 10 a 12 folhas. Sendo assim, os dados encontrados nesse trabalho estão de acordo com as afirmações do autor.

\subsubsection{Número de dias do florescimento a colheita}

A temperatura média durante a realização do experimento mostrou-se adequada para o desenvolvimento do das bananeiras, não apresentando períodos de temperatura abaixo da mínima para o crescimento das plantas. Segundo Simão (1985), temperaturas abaixo de $12^{\circ} \mathrm{C}$ paralisação nas atividades da planta. A média das temperaturas mínimas no ano de 2008 e 2009 foi de $16,35^{\circ} \mathrm{C}$ e $17,70{ }^{\circ} \mathrm{C}$, respectivamente, portanto concluise que não houve limitação de temperaturas mínimas para o crescimento das plantas. 


\section{Grupo AAA}

Grand Naine, cultivar que teve maior número de dias do florescimento a colheita, teve um total de 154 dias, 'Caipira' apresentou 121 dias, os menores valores foram observados para os cultivares 'Nanicão' com 103 dias e 'Nam' com 100 dias (Tabela 03).

Os acessos com menores intervalos entre o florescimento e a colheita, apresentam vantagem de menor permanência dos frutos no campo, ou seja, menores chances de ocorrerem injúrias aos frutos, além de retorno econômico mais rápido (DAMATTO JÚNIOR et al., 2005).

Rodrigues et al. (2006), no norte de Minas Gerais, relataram 119 dias do florescimento à colheita para 'Caipira'. Oliveira et al. (2007), em Viçosa-MG, observaram que os cultivares Grand Naine, Nam e Caipira apresentaram, respectivamente 130,30, 137,90 e 149,70 dias do florescimento à colheita. Em Lavras-MG, trabalhando em condições de sequeiro, Pereira et al. (2003) verificaram para 'Nam:' 185 dias, 'Caipira': 175 dias e 'Grand Naine': 166 dias. De acordo com Andrade et al. (2002), em Teresina-PI, 'Caipira' apresentou 97 dias do florescimento à colheita, 'Nanicão' e 'Grand Naine': 89 dias.

\section{Grupo AAB}

‘Thap Maeo' apresentou o menor valor (96 dias), tendo então menor intervalo do florescimento à colheita (Tabela 03). Entretanto, 'Prata Anã' mostrou-se mais tardia apresentando 152 dias do florescimento a colheita, sem diferir dos demais cultivares, 'Prata Zulu' teve 129 dias.

A tendência dos valores encontrados neste trabalho é confirmada pelos valores observados por Ramos et al. (2009b), que em Botucatu-SP, relataram para 'Thap Maeo' 109 dias 'Prata Anã' 126 dias e 'Prata Zulu' 118 dias. Damatto Júnior et al.(2005), nas mesmas condições edafoclimáticas observaram resultados semelhantes, ao verificar que o cultivar Prata Anã demorou 166 dias do florescimento a colheita, enquanto que 'Prata Zulu' levou 149 dias. Em Teresina-PI, Andrade et al. (2002), relataram que 'Prata Anã' apresentou 141 dias do florescimento à colheita, já ‘ Thap Maeo’ teve um intervalo de 80 dias, revelandose um cultivar bastante precoce. 
De acordo com os dados obtidos neste trabalho e na literatura consultada, pode-se inferir que independente da região em que os experimentos foram realizados, o cultivar Prata Anã apresentou maior número de dias do florescimento à colheita e ‘Thap Maeo’ foi o mais precoce, apresentando menor período.

\section{Grupo AAAB}

De acordo com as médias apresentadas na Tabela 03, não houve diferença para os híbridos 'Fhia 01', 'Fhia 18' e 'Prata Graúda', que tiveram intervalo de dias do florescimento à colheita igual a 147, 163 e 154, respectivamente. O híbrido 'Maçã Tropical' diferiu dos demais, apresentando 90 dias do florescimento à colheita.

Ramos et al. (2009b), em Botucatu-SP, observaram menores valores para os híbridos 'Fhia 01', 'Fhia 18' e 'Prata Graúda' com intervalo de dias do florescimento à colheita correspondente a 135, 138 e 111, respectivamente, e um valor próximo ao deste trabalho para o híbrido 'Maçã Tropical' (103 dias).

Avaliando o desempenho agronômico de acessos de bananeira no Norte de Minas Gerais, Rodrigues et al. (2006) observaram que o híbrido 'Fhia 18' demorou 114 dias do florescimento à colheita, 'Fhia 01' 115 dias e 'Prata Graúda' 111 dias. Entretanto, em condições de sequeiro, Pereira et al. (2003) em Lavras-MG, relataram para 'Fhia 18', 'Fhia 01'e 'Prata Graúda' 166, 165 e 145 dias, respectivamente. Em Viçosa-MG, Oliveira et al. ( 2007) verificaram 118,4 dias do plantio ao florescimento para 'Fhia 18' e 147 dias para 'Fhia $01^{\prime}$.

Os Híbridos 'Fhia 18', 'Fhia 01' e 'Prata Graúda' em qualquer região em que foram cultivados apresentaram valores semelhantes, sendo que essa resposta pode ser atribuída ao fato de todos esses híbridos serem oriundos do cultivar 'Prata anã'.

\section{Grupo ABB}

'Figo Cinza' apresentou 133 dias do florescimento à colheita (Tabela 03). Ramos et al. (2009a), em Botucatu-SP, observaram que esse mesmo cultivar demorou 77 dias do florescimento à colheita, este valor é bem menor que o relatado neste trabalho. 


\subsection{Características de produção}

\subsubsection{Peso dos frutos \\ Grupo AAA}

Grand Naine foi o cultivar que apresentou o maior peso de frutos (28,42 Kg), diferindo do 'Nanicão', 'Caipira' e 'Nam' que apresentaram 19,27, 14,48 e 10,32 Kg, respectivamente. 'Caipira' teve peso intermediário entre 'Nanicão' e 'Nam', não havendo diferenças entre esses cultivares. (Tabela 04).

Ramos et al. (2009b), em Botucatu-SP, avaliando o primeiro ciclo de produção, observaram maior peso dos frutos para 'Grand Naine'( 29,30 Kg) e 'Nanicão' $(23,40 \mathrm{Kg})$. Entretanto, para os cultivares Caipira e Nam, relataram menor peso dos frutos em relação a este trabalho, sendo 13,33 e $8,45 \mathrm{Kg}$, respectivamente.

Donato et al. (2006), em Guanambi-BA, relataram que os frutos de 'Grand Naine' pesaram 39,78 Kg e os de 'Nanicão' 40,54 Kg no segundo ciclo de produção. Rodrigues et al. (2006), no norte de Minas Gerais observaram que o cultivar 'Caipira' teve peso de frutos igual a 16,1 Kg. Em Rio Branco-AC, Ledo et al. (1997), avaliando três ciclos de produção de diferentes acessos de bananeira, relataram que no segundo ciclo os frutos do cultivar 'Nam' pesaram $6,43 \mathrm{Kg}$.

\section{Grupo AAB}

Como pode ser observado na Tabela 04, o cultivar Thap Maeo, apesar de apresentar maior peso dos frutos $(17,72 \mathrm{Kg})$, não diferiu dos cultivares Prata Anã e Prata Zulu que tiveram seus frutos pesando 14,45 e $16,71 \mathrm{Kg}$, respectivamente.

Em Botucatu-SP, Ramos et al. (2009b), nas mesmas condições em que foi realizado este experimento, também não verificaram diferenças no peso dos frutos para 'Prata Zulu' e 'Thap Maeo', verificando valores iguais a 17,20 e 16,14, respectivamente.

Rodrigues et al. (2006), no Norte de Minas Gerais e Donato et al. (2006) em Guanambi-BA, observaram para 'Prata Anã' 18,8 e 24,9 Kg, respectivamente, valores superiores aos encontrado neste trabalho. Em Teresina-PI, Ledo et al. (1997), 
relataram que o cultivar Tha Maeo teve no segundo ciclo de produção peso de fruto igual a $16,13 \mathrm{Kg}$.

\section{Grupo AAAB}

O peso dos frutos neste grupo variou de 9,89 Kg para 'Maçã Tropical a 32,86 Kg para 'Fhia 01'(Tabela 04). Os frutos do híbrido 'Prata Graúda' pesaram 24,33 Kg, porém não diferiu do 'Fhia 18' que apresentou peso de fruto igual a 19,8 Kg.

Em Botucatu-SP, Ramos et al. (2009b), avaliando o desempenho de cultivares e híbridos de bananeira, observaram no primeiro ciclo de produção que os híbridos 'Fhia 01' e 'Prata Graúda' apresentaram maior peso de fruto, correspondendo a 26,94 e 24,44 $\mathrm{Kg}$, respectivamente.

No norte de Minas Gerais, Rodrigues et al. (2006), verificaram que os frutos do híbrido 'Fhia 01' pesaram 34,00 Kg, 'Prata Graúda' 36,20 Kg e 'Fhia 18': 30,00 Kg. Em todos os trabalhos citados 'Fhia 01' e 'Prata Graúda' apresentaram maior peso de fruto, corroborando com os resultados encontrados neste trabalho.

\section{Grupo ABB}

'Figo Cinza' apresentou peso de frutos igual a 7,67 Kg (Tabela 04), apresentado menor peso de frutos quando comparado aos outros acessos. Em Botucatu-SP, Ramos et al. (2009a), observaram frutos de 'Figo Cinza' pesando 7,96 Kg. 
Tabela 04 Valores médios de peso de frutos (PF), peso do engaço (PENG), peso do cacho (PC), número de frutos por cacho $\left(\mathrm{N}^{\circ} \mathrm{F}\right)$, peso médio dos frutos (PMF) e produtividade (PROD) de acessos de bananeira em Botucatu-SP (março de 2008 a maio de 2009).

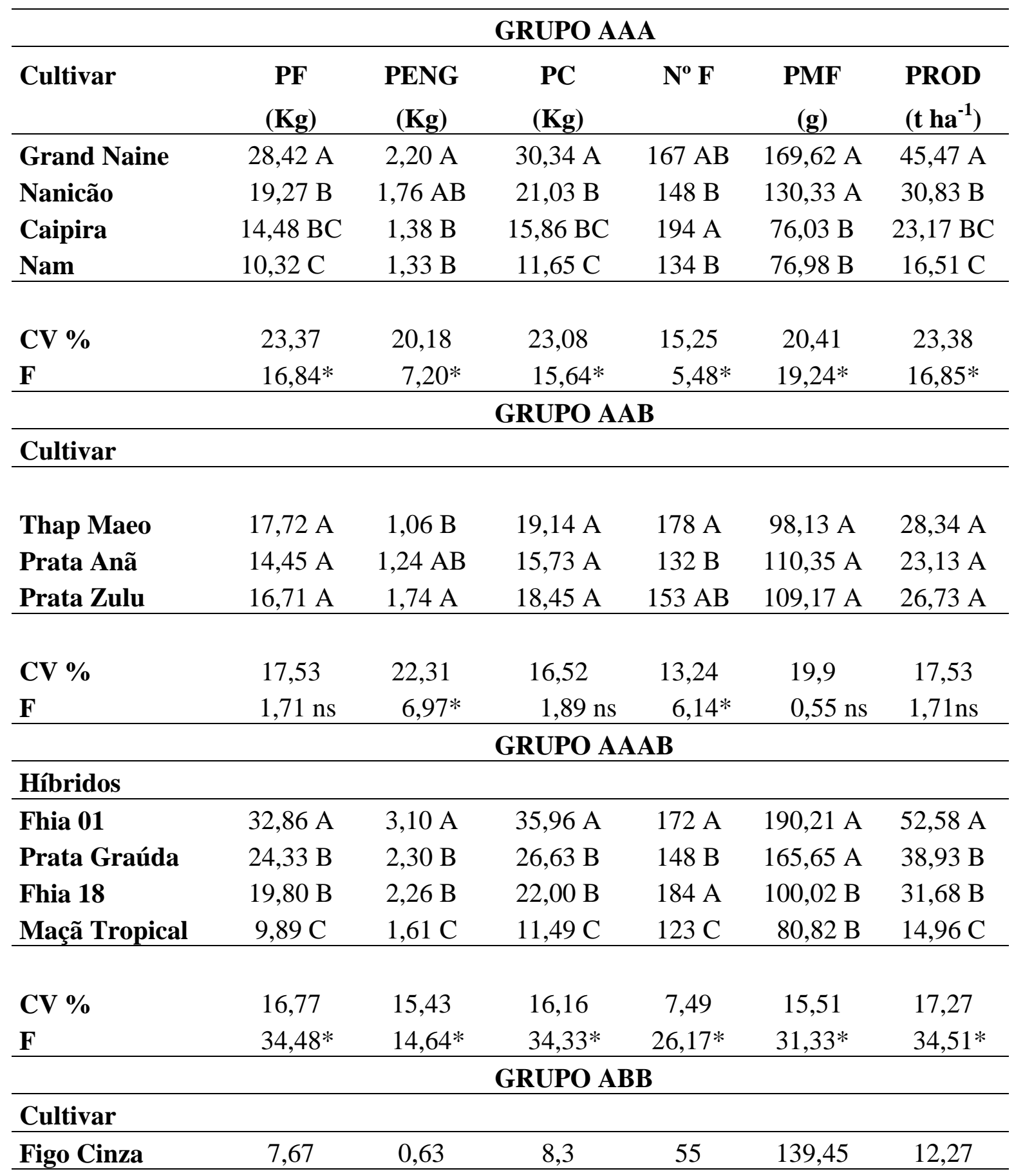

Médias seguidas das mesmas letras na coluna não diferem entre si pelo teste de Tukey a 5\% de probabilidade. 


\subsubsection{Peso do engaço \\ Grupo AAA}

'Grand Naine’ apresentou engaço mais pesado (2,20 Kg) (Tabela 04) quando comparado com 'Caipira' e 'Nam' que tiveram peso do engaço correspondente a 1,38 e $1,33 \mathrm{Kg}$, respectivamente. O cultivar 'Nanicão' não diferiu dos cultivares mencionados, apresentando peso de $1,76 \mathrm{Kg}$.

Resultados semelhantes foram relatados por Ramos et al. (2009b), em Botucatu-SP que observaram maior peso de engaço para os cultivares Grand Naine e Nanicão (2,58 e 2,12 Kg) e menor peso para 'Caipira' e 'Nam'(1,53 e 1,50 Kg, respectivamente).

Em Jataí-GO, Santos et al. (2006) observaram para 'Caipira' peso de engaço de 0,71 Kg. Ganga et al. (2002), avaliando seis acessos de bananeira em Jaboticabal$\mathrm{SP}$, relataram que o engaço de 'Nanicão' pesou 1,02 Kg. Esses valores são inferiores aos do presente trabalho .

\section{Grupo AAB}

Os dados apresentados na Tabela 04 indicam que o cultivar Prata Zulu teve maior média para peso do engaço $(1,74 \mathrm{Kg})$, ao passo que a menor média para esta característica foi representada pelo cultivar Thap Maeo (1,06 Kg). Já 'Prata Anã'com peso de engaço igual a 1,24 Kg, não diferiu dos outros cultivares.

Em Botucatu, Ramos et al. (2009b), avaliando os mesmos cultivares, notaram que o engaço do cultivar Prata Zulu pesou 1,90, Thap Maeo: 1,44 e Prata Anã 1,14 Kg. Observa-se que 'Prata Zulu' teve maior peso do engaço, corroborando com os resultados do presente trabalho.

Santos et al. (2006), em Jataí-GO, no segundo ciclo de produção notaram que o cultivar Thap Maeo apresentou peso de engaço igual a 1,01 Kg. Também no segundo ciclo de produção, Ganga et al. (2002), em Jaboticabal-SP, verificaram que o engaço do cultivar Prata Anã pesou 0,92 Kg. 


\section{Grupo AAAB}

O peso do engaço neste grupo variou de 3,10 Kg para 'Fhia 01' a 1,61 Kg para 'Maçã Tropical'(Tabela 04). Não houve diferença entre os híbridos 'Prata Graúda' e 'Fhia 18', apresentando peso de engaço correspondente a 2,30 e 2,26 Kg.

Ramos et al. (2009b), estudando o desempenho de genótipos de bananeira em Botucatu-SP, verificaram maior peso de engaço para 'Fhia 01'(3,28 Kg), quando comparada a 'Prata Graúda', 'Fhia 18' e 'Maçã Tropical' que apresentaram 2,48, 2,10 e 1,90 $\mathrm{Kg}$, respectivamente.

Ganga et al. (2002), em Jaboticabal-SP, relataram que o engaço do híbrido 'Fhia 01' pesou 1,16 Kg e 'Fhia 18' 0,87 Kg. Santos et al. (2006), em Jataí-GO, avaliando os mesmos genótipos observaram que 'Fhia 01' apresentou engaço com peso igual a $1,25 \mathrm{Kg}$ e do 'Fhia 18 ' pesou $1,62 \mathrm{Kg}$.

\section{Grupo ABB}

O cultivar Figo Cinza, apresentou peso de engaço correspondente a 0,63 Kg. Ramos et al. (2009a), encontraram peso de engaço para o cultivar Figo Cinza igual a $1,20 \mathrm{Kg}$.

\subsubsection{Peso do cacho}

\section{Grupo AAA}

'Grand Naine' apresentou cacho mais pesado (30,34 Kg), enquanto que 'Nanicão' e 'Caipira' tiveram pesos intermediários (21,03 e 15,86 kg, respectivamente). O cultivar Nam apresentou menor peso de cacho $(11,65 \mathrm{~kg})$ (Tabela 04).

Segundo Alves (1999), o peso do cacho é a principal característica que expressa a produtividade, todavia não pode ser considerado isoladamente, pois outros atributos exercem influência na preferência do mercado consumidor, especialmente o sabor do fruto.

Ramos et al. (2009b), em Botucatu-SP, observaram que os cultivares Grand Naine e Nanicão apresentaram cachos mais pesados (31,88 e 25,16 Kg) 
respectivamente, em relação aos cvs. Caipira e Nam que tiveram peso de cacho igual a 14,87 e $9,55 \mathrm{Kg}$.

Donato et al. (2003), em Guanambi-BA, verificaram para 'Grand Naine' peso de cacho correspondente a 29,50 Kg, 'Caipira': 15,60 Kg e 'Nam': 13,90 Kg. De acordo com Silva et al. (2002), em Cruz das Almas-BA, o cacho do cultivar Grand Naine pesou 15,90 Kg, 'Caipira': 21,10 Kg e 'Nam': 12,90 Kg. enquanto, em Lavras-MG, Pereira et al. (2003), observaram que os mesmos cultivares apresentaram cachos menos pesados: 13,85, 7,40 e $8,32 \mathrm{Kg}$, respectivamente.

Em Guanambi-BA, Donato et al. (2006) encontraram para 'Nanicão' cacho com peso de 44,17 Kg e para 'Grand Naine' 43,24 Kg. Entretanto, em Rio Branco-AC, Oliveira et al. (2008) relataram peso de cacho inferior para os mesmos cultivares, sendo 8,36 Kg para 'Nanicão' e 7,71 Kg para 'Grand Naine'. Ledo et al. (1997), em Rio Branco-AC, 'Nam' teve cacho pesando 7,38 Kg e 'Caipira' 5,84 Kg. Segundo Santos et al. (2006), em Jataí-GO, o cultivar 'Caipira' pesou 9,80 Kg.

A literatura especializada na área corrobora com os resultados obtidos neste trabalho, em que 'Grand Naine' apresentou maior peso de cacho e Nam teve um cacho menos pesado.

\section{Grupo AAB}

As médias de peso do cacho para este grupo foram próximas, e portanto não houve diferença entre os cultivares. O cacho de 'Thap Maeo' pesou 19,14 Kg, 'Prata Anã' 15,73 kg e 'Prata Zulu’ 18,45 Kg (Tabela 04).

Segundo Moreira (1999), 'Prata Zulu' pode apresentar peso de cacho que varia entre 20 a $25 \mathrm{Kg}$, sendo que o valor encontrado neste trabalho está próximo deste intervalo. Em Botucatu-SP, Damatto Júnior (2008), observou para 'Prata Anã' um peso de cacho igual a 19,90 Kg. Donato et al. (2006a), em Guanambi-BA, relataram também para 'Prata Anã' 15 e 28,01 Kg, respectivamente. Gonçalves et al. (2008), no Norte de Minas Gerais verificaram que o cacho da 'Prata Anã' pesou 8,54 Kg e 'Thap Maeo' 15,78 Kg. De acordo com Ledo et al. (2008), em Propriá-SE, os mesmos cultivares apresentaram peso de cacho correspondente a 15,82 e $20,28 \mathrm{Kg}$, respectivamente. 
Ledo et al. (1997) em Rio Branco-AC e Santos et al. (2006), em JataíGO, registraram para 'Thap Maeo' cachos pesando 18,90 e 12,94Kg, respectivamente. Assim como verificado neste trabalho, bem como nas citações, o cultivar 'Thap maeo' apresentou maior peso de cacho.

\section{Grupo AAAB}

'Fhia 01' apresentou maior peso de cacho $(35,96 \mathrm{Kg})$, seguida pela 'Prata Graúda', com cacho de 26,63 Kg e 'Fhia 18' com 22 Kg (Tabela 04). O híbrido 'Maçã Tropical' teve um cacho com menor peso $(11,49 \mathrm{Kg})$.

Ramos et al. (2009b), em Botucatu-SP, avaliando os mesmos híbridos relataram para 'Fhia 01' cacho com peso de 30,22 Kg, 'Prata Graúda' 26,92 Kg, 'Fhia 18' 20,74 Kg e 'Maçã Tropical' 18,58 Kg.

Silva et al. (2002a), em Petrolina-PE e Ledo et al. (2008), em PropriáSE, verificaram que o cacho do híbrido 'Fhia 18' pesou 19,40 e 20,15 Kg, respectivamente. Em condições de sequeiro, Pereira et al. (2003), em Lavras-MG, registraram para 'Fhia 01', 'Prata Graúda' e 'Fhia 18' cachos com pesos de 13,35, 16,58 e 10,64 Kg, respectivamente. Segundo Donato et al. (2003), em Guanambi-BA, o cacho do híbrido 'Fhia 01' pesou 14,20 Kg, 'Prata Graúda' 23,60 Kg e 'Fhia 18' 16,30 Kg. Contudo, Rodrigues et al. (2006), em Viçosa-MG, encontraram para os mesmos híbridos peso de cacho igual a 34, 36,02 e 30,5 Kg, respectivamente. No Recôncavo Baiano, Lima et al. (2005), relataram para 'Maçã Tropical' um cacho com peso de 16,07 Kg e para 'Prata Graúda' 14, $62 \mathrm{Kg}$.

Os híbridos 'Fhia 01' e 'Prata Graúda' na maioria dos trabalhos apresentaram melhor desempenho no que diz respeito ao peso do cacho, o que está de acordo com valores encontrados neste trabalho.

\section{Grupo ABB}

'Figo Cinza' apresentou cacho com peso de 8,30 Kg (Tabela 04). Ramos et al. (2009a) observaram peso de cacho correspondente a 9,16 Kg. 


\subsubsection{Número de frutos por cacho \\ Grupo AAA}

'Caipira' foi o cultivar que apresentou mais frutos por cacho (194), seguido de 'Grand Naine' com 167 frutos, 'Nanicão' com 148 frutos e 'Nam' com 134 não diferindo entre si (Tabela 04).

Segundo Silva et al. (2000), o número de frutos é uma importante característica para o melhoramento genético, pois está estreitamente relacionado ao tamanho e peso do cacho, expressando assim a produtividade do genótipo.

Em Botucatu, Ramos et al. (2009b) observaram para 'Grand Naine' cacho com 192 frutos e no mesmo trabalho 'Nanicão', 'Caipira' e 'Nam' apresentaram respectivamente, 163, 159 e 104 frutos por cacho. Leonel et al. (2004), na mesmas condições constataram para o cultivar Nanicão 141 frutos por cacho. Ganga et al. (2002), em JaboticabalSP e Lima et al. (2005) no Recôncavo Baiano, observaram para o mesmo cultivar cachos com 136 e 123 frutos, respectivamente.

Pereira et al. (2003), em Lavras-MG, constataram que o cultivar Grand Naine apresentou 109,30 , Caipira 102,28 e Nam 88,32 frutos por cacho. Em trabalho realizado em Rio Branco-AC, Ledo et al. (1997) relataram que 'Caipira' teve cacho com 98,86 e 'Nam' apresentou 99,73 frutos. Em Cruz das Almas-BA, Silva et al. (2002) observaram que 'Grand Naine', 'Caipira' e 'Nam' apresentaram, respectivamente, 126, 173 e 103 frutos por cacho. Ledo et al. (2008), em Propriá-SE e Gonçalves et al. (2008), em Janaúba-MG, registraram para 'Caipira' número de frutos por cacho igual a 189 e 93 frutos, respectivamente. Para o mesmo cultivar, Rodrigues et al. (2006), no Norte de Minas Gerais, encontraram 173 frutos por cacho.

É possível observar que mesmo com a variação do número de frutos por cacho para cada região, na maioria dos trabalhos citados 'Caipira' e 'Grand Naine' tiveram melhor resposta para esta característica. 'Nanicão' apresentou valores intermediários e os menores valores foram apresentados pelo cultivar Nam. Portanto, esses resultados confirmam os encontrados nesta pesquisa. 


\section{Grupo AAB}

O número de frutos por cacho neste grupo variou de 132 frutos para 'Prata Anã a 178 para 'Thap Maeo'. 'Prata Zulu' não diferiu dos outros cultivares apresentando 153 frutos por cacho (Tabela 04).

Ramos et al. (2009b), em Botucatu-SP relataram maior número de frutos para os cultivares Thap Maeo (174 frutos) e Prata Zulu (180 frutos), enquanto que 'Prata Anã' teve menos frutos por cacho (85 frutos). Entretanto, nas mesmas condições Damatto Júnior (2008), em Botucatu-SP, verificou para 'Prata Anã' 163 frutos por cacho. Rodrigues et al. (2006), no Norte de Minas Gerais e Donato et al. (2003) em Guanambi-BA, observaram que o cultivar Prata Anã apresentou respectivamente, 134 e 131 frutos por cacho.

Ledo et al. (2008), em Propriá-SE, constataram que 'Thap Maeo' teve um cacho com 223 frutos. Porém, Gonçalves et al. (2008), em Janaúba-MG encontraram para esse mesmo cultivar 273 frutos por cacho. Silva et al. (2002), em Cruz das Almas-BA, relataram que o cultivar Thap Maeo teve 184 frutos por cacho, ao passo que 'Prata Anã' apresentou 103 frutos. Pereira et al. (2003), em Lavras-MG, verificaram para mesmo cultivar um número de frutos por cacho correspondente a 92. Ledo et al. (1997), em Rio Branco-AC, constataram para 'Thap Maeo' 195 frutos por cacho.

O cultivar Thap Maeo apresentou na maioria das citações melhor desempenho para o número de frutos por cacho, o que corrobora os resultados apresentados no presente trabalho.

\section{Grupo AAAB}

'Fhia 01 ' e 'Fhia 18' apresentaram valores aproximados (172 e 184 frutos por cacho) respectivamente, não havendo portanto diferença entre esses híbridos. O híbrido 'Prata Graúda' teve um cacho com 148 frutos, seguida de 'Maçã Tropical' com 123 frutos por cacho (Tabela 04).

Ramos et al. (2009b), nas mesmas condições observaram que 'Fhia 01' teve um cacho com 167 frutos não diferindo de 'Fhia 18'com 163 frutos. Essa tendência foi observada para os mesmo híbridos no trabalho em questão. 
Lima et al. (2005), em Cruz das Almas-BA, encontraram para os híbridos 'Maçã Tropical' e 'Prata Graúda' um cacho com 122 e 98 frutos, respectivamente. Pereira et al. (2003) avaliando diferentes acessos de bananeira em Lavras-MG, constataram que o híbrido 'Prata Graúda' teve um cacho com 96 frutos, 'Fhia 01': 99 frutos e 'Fhia 18': 93 frutos. No Norte de Minas Gerais, Rodrigues et al. (2006), verificaram para esses mesmos híbridos uma média de 155, 193 e 180 frutos por cacho, respectivamente. Ledo et al. (2008) em Propriá-SE, observou 130 frutos por cacho para 'Fhia 18'.

Nos resultados deste trabalho e nas referências citadas 'Fhia 01' e 'Fhia 18' apresentaram cachos com maior número de frutos.

\section{Grupo ABB}

'Figo Cinza' teve um cacho com 55 frutos (Tabela 04). Ramos et al. (2009a), observaram o mesmo número de frutos por cacho nesse cultivar (55).

\subsubsection{Peso médio dos frutos \\ Grupo AAA}

Os maiores valores para peso médio dos frutos foram observados para os cultivares 'Grand Naine' e 'Nanicão', o primeiro pesou 169,62 g e o segundo 130,33 g (Tabela 04). 'Caipira' e 'Nam' não diferiram entre si apresentando peso médio de frutos igual a 76,03 e $76,98 \mathrm{~g}$, respectivamente.

De acordo com Ramos et al. (2009b), em Botucatu-SP, os frutos do cultivar Grand Naine pesaram 152,81 g, Nanicão 142,18 g, Caipira 83,77 g e Nam 81,02 g.

Em Cruz das Almas-BA, Lima et al. (2005), observaram que o cultivar Nanicão apresentou peso médio frutos correspondente a 116,61 g. Maiores valores para os mesmos cultivares foram encontrados por Donato et al. (2006), em Guanambi-BA, os frutos do cultivar Nanicão tiveram peso médio de 217,58 g e os frutos de 'Grande Naine' pesaram 217,25 g. Pereira et al. (2003), em condições de sequeiro no município de Lavras-MG, os autores verificaram que os cultivares Grande Naine, 'Caipira' e 'Nam' apresentaram frutos com peso médio de 120,50 , 72,48 e 94,21 g, respectivamente. Rodrigues et al. (2006) no Norte de Minas Gerais e Ledo et al. (2008) em Propriá-SE, constataram para 'Caipira' peso 
médio de fruto correspondente a 97 e 89,20 g, respectivamente. Ledo et al. (1997) em Rio Branco-AC relataram que os frutos do cultivar 'Caipira pesaram $85 \mathrm{~g} \mathrm{e}$ 'Nam' teve seus frutos pesando $89 \mathrm{~g}$.

\section{Grupo AAB}

Não houve diferença entre os cultivares pertencentes a este grupo, onde 'Thap Maeo', 'Prata Anã' e 'Prata Zulu' apresentaram, respectivamente, 98,13, 110,35 e $109,17 \mathrm{~g}$ por fruto (Tabela 04).

Em Botucatu-SP, Ramos et al. (2009b), relataram que 'Thap Maeo' que os frutos do cultivares Thap Maeo pesaram 92,34 g, Prata Anã 99,27 g e Prata Zulu 95,43 g. Segundo os autores, não houve diferença entre tais cultivares. Essa observação é semelhante a deste trabalho.

Os resultados deste trabalho estão próximos dos encontrados por Ledo et al. (2008), que em Propriá-SE, observaram peso médio de fruto para os cultivares Thap Maeo e Prata Anã correspondente a 86,7 g e 116,3 g, respectivamente. Entretanto, Rodrigues et al. (2006) no Norte de Minas Gerais e Donato et al. (2006) em Guanambi-BA relataram resultados superiores para 'Prata Anã', 140 g e 155,80 g, respectivamente. Em condições de sequeiro, Pereira et al. (2003), em Lavras-MG, observaram para o mesmo cultivar um peso médio de fruto referente a 95,08 g. Em Rio Branco-AC, Ledo et al. (1997), constataram que os frutos de 'Thap Maeo' apresentaram um peso médio de $83 \mathrm{~g}$.

\section{Grupo AAAB}

Os frutos do híbrido 'Fhia 01' apresentaram peso médio de fruto igual a 190,21 g, já os frutos de 'Prata Graúda' pesaram 165,65 g, com esses valores não houve diferença entre estes híbridos. O mesmo foi verificado para os híbridos 'Fhia 18' e 'Maçã Tropical', em que o primeiro teve peso médio de fruto correspondente a 100,02 g e o segundo de $80,82 \mathrm{~g}$ (Tabela 04).

Ramos et al. (2009b), em Botucatu-SP, avaliando acessos de bananeira, notaram resultado semelhante ao deste trabalho, verificaram que os híbridos 'Fhia 01' e 'Prata Graúda' tiveram valores aproximados de peso médio de fruto, 161,16 e 179,68 g, 
respectivamente. No mesmo trabalho foi observado também que 'Fhia 18' e 'Maçã Tropical' não diferiram entre si, em que os pesos médio dos frutos desses híbridos foram, respectivamente, 114 e $122,55 \mathrm{~g}$.

Segundo Pereira et al. (2003), em Lavras-MG, os frutos dos híbridos 'Fhia 01', 'Prata Graúda' e 'Fhia 18' apresentaram peso médio de 134,61, 172,02 e 113,45 g, respectivamente. Entretanto, Rodrigues et al. (2006) no Norte de Minas Gerais verificaram que o peso médio dos frutos do híbrido 'Fhia 01' foi de $177 \mathrm{~g}$, 'Prata Graúda' $234 \mathrm{~g}$ e 'Fhia 18' 169 g. Cerqueira et al. (2002), em Cruz das Almas-BA, relataram para 'Maçã Tropical' peso médio de frutos de 135,4 g e para 'Prata Graúda' $215 \mathrm{~g}$. Nas mesmas condições Lima et al. (2005), avaliando os mesmos híbridos, constataram que os frutos de 'Maçã Tropical' e 'Prata Graúda' pesaram, respectivamente, 99,82 g e 132,64 g. Em Propriá-SE, Ledo et al. (2008), observaram para o híbrido 'Fhia 18' peso médio de fruto correspondente a 144,2 g.

Com base nos valores observados no trabalho em questão e nas citações é possível inferir que na maioria dos casos, os híbridos 'Fhia 01' e 'Prata Graúda' apresentaram maior peso médio de fruto.

\section{Grupo ABB}

O Cultivar Figo Cinza apresentou frutos com peso médio de 139,45 g (Tabela 04). Sgarbieri et al. (1965), observaram para 'Figo Cinza' valores variando de $163 \mathrm{~g}$ no dia da colheita e $128 \mathrm{~g}$ no $10^{\circ}$ dia de armazenamento. Entretanto, maiores valores foram observados por Gonzaga Neto et al. (1993), onde no submédio São Francisco esse mesmo cultivar apresentou um peso médio de fruto correspondente a $320 \mathrm{~g}$. Este maior peso pode está relacionado as melhores condições climáticas para cultura que ocorre nessa região.

\subsubsection{Produtividade \\ Grupo AAA}

Grand Naine foi o cultivar mais produtivo deste grupo, com 45,47 tha ${ }^{1}$ (Tabela 04), seguida por 'Nanicão', 'Caipira' e 'Nam' que apresentaram 30,83, 23,17 e 16,51 t $\mathrm{ha}^{-1}$, respectivamente (Tabela 04). 
Oliveira et al. (2008), em Rio Branco-AC verificaram que 'Grand Naine' atingiu uma produtividade de 11,57 t ha ${ }^{-1} \mathrm{e}$ ' Nanicão' $12,53 \mathrm{t} \mathrm{ha}^{-1}$. Gonçalves et al. (2008), em Janaúba-MG, observaram que o cultivar 'Caipira' teve uma produtividade de 9,9 t $\mathrm{ha}^{-1}$. Estes valores são inferiores aos relatados neste trabalho.

\section{Grupo AAB}

De acordo com a Tabela 04, não houve diferença entre os cultivares deste grupo, 'Thap Maeo' apresentou uma produtividade de 28,34 t ha ${ }^{-1}$, 'Prata Zulu': 23,13 t ha $^{-1}$ e 'Prata Anã' 26,73 t ha ${ }^{-1}$.

Gonçalves et al. (2008) observaram para os cultivares Thap Maeo e Prata Anã produtividade correspondente a 26,3 $\mathrm{t} \mathrm{ha}^{-1}$ e 14,22 $\mathrm{t} \mathrm{ha}{ }^{-1}$. Em Rio Branco-AC, Oliveira et al. (2008), constataram uma produtividade para 'Prata Anã' referente a 7,50 t ha ${ }^{-1}$. Moreira (1999), reportou para 'Prata Zulu' produtividade de $33 \mathrm{t}$ ha- ${ }^{1}$. Os resultados citados pelos autores foram inferiores aos apresentados neste trabalho, exceto para 'Prata Zulu', onde os resultados foram maiores que os presentes trabalhos.

\section{Grupo AAAB}

O híbrido 'Fhia 01'destacou-se neste grupo, com produtividade de 52,58 t ha ${ }^{-1}$, já os híbridos 'Prata Graúda' e 'Fhia 18' não diferiram entre si, apresentando produtividade de 38,93 e 31,68 $\mathrm{t} \mathrm{ha}^{-1}$, respectivamente. 'Maçã Tropical' apresentou menor produtividade, $14,96 \mathrm{t} \mathrm{ha}^{-1}$.

\section{Grupo ABB}

'Figo Cinza' apresentou produtividade de 12,27 t ha ${ }^{-1}$ (Tabela 04). Ramos et al. (2009a), verificaram para o mesmo cultivar produtividade equivalente a $12,74 \mathrm{t}$ $\mathrm{ha}^{-1}$, resultado que está próximo do encontrado neste trabalho. 


\subsubsection{Número de pencas}

\section{Grupo AAA}

'Nanicão' e 'Caipira' apresentaram maior número de pencas, sendo 10,20 e 9,80 respectivamente, seguidos de 'Grand Naine' que teve um cacho com 9,60 pencas (Tabela 05). O cultivar Nam apresentou menor número pencas $(8,20)$.

Donato et al. (2003), em Guanambi-BA, relataram que o cultivar Caipira apresentou 9,30 pencas por cacho, 8,20 pencas para 'Nam' e 11,10 pencas para 'Grand Naine'. Os valores encontrados pelos autores estão próximos aos encontrados neste trabalho. Gonçalves et al. (2008), em Janaúba-MG, observaram que o cultivar Caipira teve um cacho com 8,80 pencas. Santos et al. (2006) em Jataí-GO, constataram para o mesmo cultivar número de pencas igual a 7,39. Ledo et al. (1997) em Rio Branco-AC, encontrou para 'Caipira' e 'Nam,' respectivamente, 6,09 e 6,87 pencas por cacho.

\section{Grupo AAB}

'Thap Maeo' apresentou maior número de pencas por cacho (12), diferindo dos cultivares Prata Anã e Prata Zulu que tiveram cachos com 9,60 e 9,80 pencas (Tabela 05).

Segundo Gonçalves et al. (2008), no município de Janaúba-MG, os cachos de 'Thap Maeo' e 'Prata Anã' apresentaram 13,90 e 7,90 pencas, respectivamente. Donato et al. (2003), em Guanambi-BA e Rodrigues (2006), no Norte de Minas Gerais, constataram 8,80 e 9,60 pencas para 'Prata Anã,' respectivamente. Em relação ao cultivar Thap Maeo Santos et al. (2005), em Jataí-GO e Ledo et al. (1997), em Rio Branco-AC, observaram cachos 9,60 e 12,53 pencas, respectivamente.

Rodrigues et al. (2006), no Norte de Minas Gerais, verificaram cachos com 10 pencas para 'Prata Graúda', 11,60 para 'Fhia 01' e 11,30 para 'Fhia 18'. Segundo Donato et al. (2003), em Guanambi-BA, os mesmos híbridos apresentaram cachos com 9,50, 8,90 e 8,90 pencas, respectivamente. Em Jataí-GO, Santos et al. (2006) relataram que o híbrido 'Fhia 01 ' teve um cacho com 9,34 pencas e 'Fhia 18' 9,56 pencas. 
Tabela 05. Valores médios de número de pencas $\left(\mathrm{N}^{\circ} \mathrm{P}\right)$, peso da $2^{\mathrm{a}}$ penca $\left(\mathrm{P} 2^{\mathrm{a}} \mathrm{P}\right)$, número de frutos na $2^{\mathrm{a}}$ penca $\left(\mathrm{F}^{\circ} \mathrm{P}\right)$, comprimento $(\mathrm{CF})$ e diâmetro de frutos (DF) de acessos de bananeiras, Botucatu-SP (março de 2008 a maio de 2009).

\begin{tabular}{|c|c|c|c|c|c|}
\hline \multicolumn{6}{|c|}{ GRUPO AAA } \\
\hline Cultivar & $\mathbf{N}^{\circ} \mathbf{P}$ & $\begin{array}{c}\mathbf{P}^{\mathrm{a}} \mathbf{P} \\
(\mathrm{Kg})\end{array}$ & F $2^{\mathrm{a}} \mathbf{P}$ & CF & DF \\
\hline Grand Naine & $9,60 \mathrm{AB}$ & $3,84 \mathrm{~A}$ & $19,80 \mathrm{AB}$ & $22,93 \mathrm{~A}$ & $36,92 \mathrm{~A}$ \\
\hline Nanicão & $10,20 \mathrm{~A}$ & $3,20 \mathrm{AB}$ & $19,00 \mathrm{~B}$ & $21,30 \mathrm{~A}$ & $37,74 \mathrm{~A}$ \\
\hline Nam & $9,80 \mathrm{~A}$ & $2,06 \mathrm{BC}$ & $26,00 \mathrm{~A}$ & $15,89 \mathrm{~B}$ & $30,52 \mathrm{~B}$ \\
\hline Caipira & $8,20 \mathrm{~B}$ & $1,63 \mathrm{C}$ & $19,40 \mathrm{~B}$ & $15,40 \mathrm{~B}$ & $31,80 \mathrm{~B}$ \\
\hline CV\% & 10,23 & 23,89 & 16,8 & 7,05 & 5,94 \\
\hline $\mathbf{F}$ & $3,6^{*}$ & $12,6^{*}$ & $7,87 *$ & $40,66^{*}$ & $15,82^{*}$ \\
\hline \multicolumn{6}{|c|}{ GRUPO AAB } \\
\hline \multicolumn{6}{|l|}{ Cultivar } \\
\hline Thap Maeo & $12,02 \mathrm{~A}$ & $1,84 \mathrm{~A}$ & $21,00 \mathrm{~A}$ & $15,37 \mathrm{~B}$ & $33,80 \mathrm{~A}$ \\
\hline Prata Anã & $9,60 \mathrm{~B}$ & $1,81 \mathrm{~A}$ & $16,00 \mathrm{~B}$ & $17,96 \mathrm{~A}$ & $36,16 \mathrm{~A}$ \\
\hline Prata Zulu & $9,80 \mathrm{~B}$ & $1,80 \mathrm{~A}$ & $15,00 \mathrm{~B}$ & $16,78 \mathrm{AB}$ & $36,00 \mathrm{~A}$ \\
\hline CV\% & 9,55 & 18,61 & 13,08 & 7,44 & 3,99 \\
\hline $\mathbf{F}$ & $8,87^{*}$ & $0,01 \mathrm{~ns}$ & $8,21 *$ & $5,45^{*}$ & $4,65 \mathrm{~ns}$ \\
\hline \multicolumn{6}{|c|}{ GRUPO AAAB } \\
\hline \multicolumn{6}{|l|}{ Híbridos } \\
\hline Fhia 01 & $11,10 \mathrm{~A}$ & $3,25 \mathrm{~A}$ & $18,00 \mathrm{~A}$ & $24,30 \mathrm{~A}$ & $39,36 \mathrm{~A}$ \\
\hline Prata Graúda & $11,03 \mathrm{~A}$ & $3,15 \mathrm{~A}$ & $18,00 \mathrm{~A}$ & $22,06 \mathrm{~A}$ & $39,76 \mathrm{~A}$ \\
\hline Fhia 18 & $9,40 \mathrm{~B}$ & $2,29 \mathrm{AB}$ & $17,00 \mathrm{~A}$ & $18,52 \mathrm{~B}$ & $34,27 \mathrm{~B}$ \\
\hline Maçã Tropical & $8,20 \mathrm{~B}$ & $1,62 \mathrm{~B}$ & $17,00 \mathrm{~A}$ & $16,20 \mathrm{~B}$ & $31,98 \mathrm{C}$ \\
\hline CV \% & 8,75 & 23,65 & 5,69 & 6,57 & 3,43 \\
\hline $\mathbf{F}$ & $12,36^{*}$ & $7,92^{*}$ & $1,01 \mathrm{~ns}$ & $36,73 *$ & $47,34^{*}$ \\
\hline
\end{tabular}

\section{Cultivar}

\begin{tabular}{llllll}
\hline Figo Cinza & 5,2 & 1,82 & 11 & 17,8 & 40,02
\end{tabular}

Médias seguidas das mesmas letras na coluna não diferem entre si pelo teste de Tukey a 5\% de probabilidade. 


\section{Grupo AAAB}

'Fhia 01' e 'Prata Graúda' não diferiram entre si, apresentando cachos com 11,10 pencas e o segundo 11,03 pencas, respectivamente (Tabela 05). Os híbridos 'Fhia 18' e 'Maçã Tropical' tiveram cachos com menor número de pencas, 9,40 e 8,20, respectivamente.

\section{Grupo ABB}

'Figo Cinza' apresentou 5,20 pencas por cacho (Tabela 05). Gonzaga Neto et al. (1993), no submédio São Francisco observaram 5 pencas para esse cultivar. Entretanto, Saes et al. (2005), relataram de 6 a 8 pencas para esse cultivar.

\subsubsection{Peso da $2^{\mathrm{a}}$ penca \\ Grupo AAA}

Com base na Tabela 05, Grand Naine foi o cultivar que apresentou maior peso da $2^{\mathrm{a}}$ penca $(3,84 \mathrm{Kg})$, seguida de 'Nanicão,' cujo peso da $2^{\mathrm{a}}$ penca foi de $3,20 \mathrm{Kg}$. 'Caipira' e 'Nam' apresentaram menores valores, 2,06 e 1,63 Kg, respectivamente.

Em pesquisa no submédio São Francisco, Gonzaga Neto et al. (1993) observaram para os cultivares Grand Naine e Nanicão, peso de 4,10 e 3,20 Kg, valores próximos aos encontrados neste trabalho. Ledo et al. (1997), em Rio Branco-AC, verificaram que a $2^{\mathrm{a}}$ penca do cultivar Caipira pesou $0,93 \mathrm{Kg}$ e 'Nam' 0,85 Kg. Ledo et al. (2008), em Propriá-SE, relataram para 'Grand Naine' e 'Caipira' peso da $2^{\mathrm{a}}$ penca correspondente a 2,72 e $1,70 \mathrm{Kg}$, respectivamente.

Rodrigues et al. (2006), no Norte de Minas Gerais e Santos et al. (2006), em Jataí-GO, observaram que a $2^{\mathrm{a}}$ penca do cultivar Caipira pesou, respectivamente, 2,2 e $1,42 \mathrm{Kg}$.

\section{Grupo AAB}

A segunda penca do cultivar Thap Maeo pesou 1,84 Kg, 'Prata Anã' 1,81 Kg e 'Prata Zulu' 1,80 Kg, não havendo diferença. (Tabela 05). 
Ramos et al. (2009b), em Botucatu-SP, estudando os mesmos cultivares, também não observou diferença para peso da $2^{\mathrm{a}}$ penca, sendo assim os resultados encontrados neste trabalho são confirmados.

Entretanto, Ledo et al. (2008), em Propriá-SE, observaram que a $2^{\text {a }}$ penca de 'Thap Maeo' pesou 1,38 Kg, ao passo que para o cultivar Prata Anã teve peso de 1,72 Kg. Santos et al. (2006), em Jataí-GO, constataram para Thap Maeo peso de 1,63 Kg, e para o mesmo cultivar, Ledo et al. (1997) verificaram peso de 1,29 Kg.

\section{Grupo AAAB}

Os híbridos 'Fhia 01' e 'Prata Graúda' apresentaram maiores valores, sendo, 3,25 e 3,15 Kg, respectivamente, porém não diferiram do híbrido'Fhia 18', que apresentou peso de 2,29 Kg e este por sua vez não diferiu de 'Maçã Tropical' que teve peso de $1,62 \mathrm{Kg}$ (Tabela 05).

Em Jataí-GO, Santos et al. (2006) observaram para o híbrido 'Fhia 01' $2^{\mathrm{a}}$ penca com peso correspondente a 2,38 $\mathrm{Kg}$ e 'Fhia 18' com 2,19 Kg. No Norte de Minas Gerais, Rodrigues (2006), relataram para os híbridos 'Fhia 01', 'Fhia 18' e 'Prata Graúda,' pesos de 4,1, 3,7 e 4,60, respectivamente. Ledo et al. (2008), em Propriá-SE, registraram para 'Fhia 18 ' peso de $2,02 \mathrm{Kg}$.

\section{Grupo ABB}

'Figo Cinza' apresentou peso da $2^{\mathrm{a}}$ penca referente a $1,82 \mathrm{Kg}$ (Tabela 05). Valores maiores foram encontrados por Gonzaga Neto et al. (1993) no submédio São Francisco, onde os autores verificaram o mesmo cultivar peso de 3,20 Kg.

\subsubsection{Número de frutos da $2^{\mathrm{a}}$ penca \\ Grupo AAA}

Caipira foi o cultivar que apresentou mais frutos na $2^{\mathrm{a}}$ penca (26). 'Nanicão' e 'Nam’ não diferiram entre si, apresentando 19 e 19,40 frutos, respectivamente. Com valores intermediários, 'Grand Naine' não diferiu de nenhum dos outros cultivares, tendo 19,80 frutos (Tabela 05). 
Segundo Gonzaga Neto et al. (1993), no submédio São Francisco, 'Grand Naine' e 'Nanicão' apresentaram 17 frutos na 2a penca. Santos et al. (2006), em JataíGO e Ledo et al. (2008), em Propriá-SE, encontraram para o cultivar Caipira 21,49 e 19,30 frutos. Para o mesmo cultivar, Rodrigues et al. (2006), no Norte de Minas Gerais observaram $2^{\mathrm{a}}$ penca com 23 frutos. Os valores encontrados pelos autores citados, estão próximos aos do presente trabalho.

\section{Grupo AAB}

'Thap Maeo' diferiu dos demais cultivares deste grupo, apresentando 21 frutos na $2^{\text {a }}$ penca (Tabela 05). 'Prata Anã,' com 16 frutos não diferiu de 'Prata Zulu' com 17 frutos.

Em Botucatu-SP, Ramos et al. (2009b) verificaram que os mesmos cultivares tiveram resposta semelhante ao observado neste trabalho, onde Thap Maeo apresentou mais frutos na $2^{\mathrm{a}}$ penca (20) quando comparado ao 'Prata Anã' e 'Prata Zulu,' que apresentaram 13 e 16 frutos, respectivamente.

Segundo Ledo et al. (2008), em Propriá-SE, 'Thap Maeo' apresentou 16,30 frutos e 'Prata Anã' 13,70 frutos na $2^{a}$ penca. Rodrigues et al. (2006), no Norte de Minas Gerais e Gonzaga Neto et al. (1993), no submédio São Francisco, observaram para 'Prata Anã' 15 e 16 frutos, respectivamente. Em relação ao cultivar Thap Maeo, Santos et al. (2006), em Jataí-GO e Ledo et al. (1997), em Rio Branco-AC, verificaram na $2^{\text {a }}$ penca, 22,60 e 15,49 frutos, respectivamente. Em todas referências citadas o cultivar Thap Maeo foi melhor em relação a esta característica. Corroborando com observado neste trabalho.

\section{Grupo AAAB}

Os híbridos não diferiram entre si, sendo que 'Fhia 01' e 'Prata Graúda' apresentaram 18 frutos na 2a penca e 'Fhia 18' e 'Maçã Tropical,' 17 frutos (Tabela 05).

Ramos et al. (2009b), trabalhando em Botucatu-SP, perceberam que os mesmos híbridos apresentaram número de frutos praticamente iguais na $2^{\mathrm{a}}$ penca, não diferindo entre si, corroborando os valores observados neste trabalho. 
Rodrigues et al. (2006), no Norte de Minas Gerais, verificaram que a $2^{\mathrm{a}}$ penca dos híbridos 'Fhia 01', 'Prata Graúda' e 'Fhia 18', tiveram respectivamente, 20, 17 e 19 frutos. Santos et al. (2006), em Jataí-GO, viram que 'Fhia 01' apresentou 16,30 e 'Fhia 18' teve 17,46 .

Os valores observados tanto no trabalho quanto nas citações tiveram puçás variações. Este resultado permite inferir que, independente da região de cultivo, os híbridos apresentaram a mesma expressão genética para a característica avaliada.

\section{Grupo ABB}

'Figo Cinza' apresentou 11 frutos por penca (Tabela 05), enquanto Gonzaga Neto et al. (1993), no submédio São Francisco, observaram 14 frutos.

\subsubsection{Comprimento dos frutos da $2^{\mathrm{a}}$ penca}

\section{Grupo AAA}

'Grand Naine' e 'Nanicão' apresentaram frutos mais compridos e não diferiram entre si. O primeiro teve frutos com 22,93 cm e o segundo 21,30 cm (Tabela 05). 'Caipira' apresentou frutos com 15,89 cm e não diferiu do cultivar Nam, que teve frutos medindo $15,40 \mathrm{~cm}$.

Segundo Ganga et al. (2002), em Jaboticabal e Lima et al. (2005), em Cruz das Almas-BA, os frutos de 'Nanicão' atingiram comprimento de 17 e 17,82 cm, respectivamente. Donato et al. (2006), em Guanambi-BA, observaram para 'Grand Naine' e 'Nanicão' frutos com comprimento de 24,06 e 24,13 cm, respectivamente. De acordo com Pereira et al. (2003), em Lavras-MG, os frutos de 'Grand Naine' atingiram comprimento de 15,32 cm, 'Nam' teve frutos com 13,56 cm e 'Caipira' com 12,21 cm. Em Cruz das AlmasBA, Silva et al. (2002) verificaram para os mesmos cultivares, frutos com comprimento de 17 , 12,80 e 13,50, respectivamente. Cerqueira et al. (2002), também em Cruz das Almas-BA, citaram que o cultivar Nam apresentou frutos com comprimento de 12,80 cm. 


\section{Grupo AAB}

Neste grupo os valores para comprimento de fruto variaram de 15,37 cm para o cultivar Thap Maeo a 17,96 cm para Prata Anã (Tabela 05). 'Prata Zulu' atingiu valor intermediário $(16,78 \mathrm{~cm})$, não diferindo dos demais cultivares.

Silva et al. (2002), em Cruz das Almas-BA, relataram que 'Prata Anã' teve frutos com comprimento de 12,7 cm e 'Thap Maeo' apresentou frutos medindo 11,5 cm. Segundo Pereira et al. (2003), em Lavras-MG e Donato et al. (2006), em Guanambi-BA, frutos do cultivar Prata Anã apresentaram comprimento de 13,61 e 18,79 cm. Para o mesmo cultivar, Rodrigues et al. (2006), no Norte de Minas Gerais, observaram frutos com comprimento de $15 \mathrm{~cm}$. Com base nos trabalhos citados, observa-se que o cultivar Prata Anã teve maior comprimento de fruto em relação aos outros cultivares, semelhante aos valores encontrados neste trabalho.

\section{Grupo AAAB}

Não houve diferença entre 'Fhia 01' e 'Prata Graúda', apresentando frutos mais compridos. Os frutos do primeiro mediram $24,30 \mathrm{~cm}$, enquanto que os do segundo 22,06 cm. Os híbridos 'Fhia 18' e 'Maçã Tropical' não diferiram entre si e o comprimento dos frutos atingiram, respectivamente, 18,52 e 16,78 cm (Tabela 05).

Segundo Lima et al. (2005), em Cruz das Almas-BA, os frutos de 'Maçã Tropical' apresentaram comprimento de 12,39 cm e os de 'Prata Graúda' mediram 15,84 cm. Em Lavras-MG, Pereira et al. (2003), verificaram que os frutos dos híbridos 'Fhia 01', 'Prata Graúda' e 'Fhia 18' atingiram comprimentos de 16,22, 17,84 e 14,46 cm, respectivamente. Ganga et al. (2002), em Jaboticabal-SP, constataram para 'Fhia 01' frutos com 16,3 e 'Fhia 18', frutos com 15,3 cm. Na maioria dos resultados observados nas citações, os maiores valores foram para os híbridos 'Fhia 01 ' e 'Fhia 18', reafirmando os resultados encontrados neste trabalho. 


\section{Grupo ABB}

Com base na Tabela 05, o cultivar Figo Cinza apresentou frutos com 17,80 cm de comprimento. De acordo com Saes et al. (2005), frutos desse cultivar podem atingir comprimento de até $20 \mathrm{~cm}$.

\subsubsection{Diâmetro dos frutos da $2^{\mathrm{a}}$ penca \\ Grupo AAA}

Os valores médios de 'Grand Naine' e 'Nanicão' não diferiram, apresentando frutos com maior diâmetro, sendo que o primeiro cultivar teve fruto com diâmetro de 36,92 mm e o segundo 37,74 mm (Tabela 05). 'Caipira' e 'Nam' não diferiram entre si, apresentando respectivamente, 30,52 e $31,80 \mathrm{~mm}$.

Donato et al. (2006), em Guanambi-BA, encontraram diâmetro para os frutos de 'Grand Naine' correspondente a 36,09 mm e para 'Nanicão' 36,46 mm, valores próximos aos encontrados neste trabalho. Entretanto, Lima et al. (2005), no Recôncavo Baiano, observaram que os frutos de 'Nanicão' apresentaram menor diâmetro $(30,10 \mathrm{~mm})$.

Segundo Pereira et al. (2003), no Norte de Minas Gerais, os cultivares Grand Naine, Caipira e Nam apresentaram frutos com diâmetro de 39,60, 32,60 e 36,50 mm, respectivamente. Rodrigues et al. (2006), em Lavras-MG e Santos et al. (2006), em Jataí-GO, constataram que o cultivar 'Caipira' apresentou frutos com 34 e 31,75 mm de diâmetro.

\section{Grupo AAB}

As médias para diâmetro de frutos neste grupo foram próximas, não havendo diferença entre os cultivares (Tabela 05). 'Thap Maeo' apresentou frutos 33,80 mm de diâmetro, 'Prata Anã' 36,16 mm e 'Prata Zulu' 36 mm.

Santos et al. (2006), em Jataí-GO, relataram que os frutos do cultivar Thao Maeo apresentaram 33,29 mm de diâmetro. Com relação ao cultivar Prata Anã, Rodrigues et al. (2006), no Norte de Minas Gerais, Pereira et al. (2003), em Lavras-MG e Donato et al. (2006), em Guanambi-BA, registraram diâmetros correspondentes a 3,80, 35,80 e $34,62 \mathrm{~mm}$. 


\section{Grupo AAAB}

'Fhia 01' e 'Prata Graúda' apresentaram as maiores médias para diâmetro de fruto (39,36 mm e 39,76 mm, respectivamente), seguidos de 'Fhia 18' que teve frutos com 34,27 mm diferindo do híbrido 'Maçã Tropical' que apresentou frutos com 31,98 mm de diâmetro (Tabela 05).

Segundo Lima et al. (2005), no Recôncavo Baiano, o híbrido 'Maçã Tropical' apresentou frutos com 32,40 mm de diâmetro e os frutos de 'Prata Graúda' tiveram 34,70 mm de diâmetro. Rodrigues et al. (2006), no Norte de Minas Gerais verificaram para os frutos dos híbridos 'Fhia 01', 'Prata Graúda' e 'Fhia 18' diâmetro referente a 37, 40 e 37 mm, respectivamente. Para os mesmos híbridos, Pereira et al. (2003), em Lavras-MG, observaram frutos com diâmetro de 39,30, 42,20 e 38,60 mm, respectivamente.

\section{Grupo ABB}

'Figo Cinza' apresentou 40,02 mm de diâmetro (Tabela 05).

As citações mostraram que os valores de diâmetro de fruto variaram para as diferentes regiões. Contudo, é importante ressaltar que esta característica é usada como parâmetro para determinar o ponto ideal de colheita. Sabe-se, portanto, que o ponto ideal de colheita varia com o objetivo de comercialização deste fruto. Para o mercado local, o fruto é colhido com maior diâmetro, já quando é destinado para mercados mais distantes da área de cultivo, deve ser colhido com menor diâmetro.

\subsection{Características de qualidade dos frutos}

\subsubsection{Textura}

\section{Grupo AAA}

'Grand Naine' e 'Nanicão' apresentaram frutos mais firmes (9,99 e 9,7 $\mathrm{N}$, respectivamente), diferindo de 'Caipira' com 7,85 N e de 'Nam', com 8,96 N (Tabela 06).

Segundo Ramos (2008), os frutos de 'Grand Naine' apresentaram firmeza de 920,50 gf. cm ${ }^{-2}$, 'Nanicão' 919,42 gf. cm ${ }^{-2}$, 'Caipira' 789,87 gf. cm ${ }^{-2}$ e 'Nam' 957,40 gf. $\mathrm{cm}^{-2}$. Estes valores em Newton, são correspondentes a 9, 8,99, 7,74 e 9,36, respectivamente, estando próximos aos observados neste trabalho. 
Cerqueira et al. (2002) verificaram que o cultivar Nam com a casca apresentando sinais de amarelo teve firmeza de 24,80 N.

\section{Grupo AAB}

Os cultivares Prata Anã e Prata Zulu não diferiram entre si, apresentando firmeza de 9,70 e 9,81 N (Tabela 06), enquanto que para 'Thap Maeo', observou-se frutos com menor firmeza $(7,44 \mathrm{~N})$.

Ramos (2008) observou que frutos de 'Thap Maeo', 'Prata Anã' e 'Prata Zulu' com cor de casca totalmente verde apresentaram respectivamente, firmeza de $704,44,928,62$ e 997,76 gf. $\mathrm{cm}^{-2}$, valores equivalentes a 6,88, 9,08 e 9,75 N. Segundo os resultados encontrados pelos autores, 'Thap Maeo' foi o cultivar com menor firmeza, este trabalho confirma o resultado observado nas citações. A firmeza do fruto é uma característica muito importante quando se considera o transporte a longas distâncias, sendo neste caso, preferível que os frutos tenham maior firmeza.

Damatto Júnior et al. (2005), constataram que frutos verdes de 'Prata Anã' apresentaram $930 \mathrm{gf} \mathrm{cm}^{-2}$ de textura, o que corresponde a 9,09 $\mathrm{N}$, enquanto Gomes (2004), relatou que este mesmo cultivar apresentou firmeza de $906,80 \mathrm{gf} \mathrm{cm}^{-2}$ ou $8,86 \mathrm{~N}$.

\section{Grupo AAAB}

Os híbridos não apresentaram diferenças entre si, sendo que para 'Fhia 01' verificou-se frutos com firmeza de 8,50 N, para 'Prata Graúda' 9,72 N, 'Fhia 18' 9,03 N e 'Maçã Tropical' 8,70 N (Tabela 06).

Segundo Ramos (2008), os frutos dos mesmos híbridos com cor de casca totalmente verde, relatou para 'Fhia 01', 'Prata Graúda', 'Fhia 18' e 'Maçã tropical' firmeza de $858,62,809,954,50$ e 867,36 gf. $\mathrm{cm}^{-2}$ ou $8,39,9,33,7,91$ e $8,48 \mathrm{~N}$, respectivamente. Cerqueira et al. (2002), estudando a firmeza dos frutos de 'Prata Graúda' e 'Maçã Tropical' com a casca apresentando sinais de amarelo e utilizando uma ponta de prova de $6 \mathrm{~mm}$ para penetrar no fruto, verificaram valores correspondentes a 35,50 e $28 \mathrm{~N}$, respectivamente. 
Com base nos resultados das citações observa-se uma variação nos valores de firmeza dos frutos, fato que pode ser explicado pelos diferentes estádios de maturação em que foram analisados. Frutos mais firmes apresentam maior resistência ao transporte e maior durabilidade pós-colheita (PEREIRA et al., 2004)

\subsection{2. $\mathrm{pH}$}

\section{Grupo AAA}

As médias de $\mathrm{pH}$ não variaram para nenhum dos cultivares, não havendo diferença. 'Grand Naine' apresentou pH igual a 5,60, 'Nanicão' 5,40, 'Caipira' 5,38 e 'Nam’ 5,55 (Tabela 06). De acordo com Bleinroth (1990), o pH de frutos em estádio verde de maturação está compreendido na faixa de 5,0 a 5,60. O mesmo autor afirma ainda, que podem ocorrer variações dentro destes limites para os diferentes cultivares de bananeira.

Em Botucatu-SP, Ramos (2008) observou que o pH de frutos verdes dos cultivares Grand Naine, Nanicão, Caipira e Nam apresentaram valores correspondentes a 5,48, 5,32, 5,45 e 5,30, respectivamente, valores próximos aos encontrados neste trabalho. Barbosa (2008), constatou que frutos verdes de 'Nanicão' apresentaram pH de 5,58. Todavia, Sgarbieri et al. (1965) notaram para o mesmo cultivar valores de $\mathrm{pH}$ variando de 5,25 em frutos verdes a 5,55 em frutos maduros.

Segundo Santos et al. (2002) e Parrela et al. (2002), verificaram valores de $\mathrm{pH}$ para frutos verdes de 'Caipira' referentes, a 5,18 e 5,47, respectivamente. Botelho et al. (2002) avaliando frutos maduros de 'Nanicão', 'Caipira' e 'Grand Naine', observaram $\mathrm{pH}$ de 4,97, 4,56 e 4,79, respectivamente. 
Tabela 06. Valores médios de textura, pH, acidez titulável (AT), sólidos solúveis (SS), de frutos de acessos de bananeira, Botucatu-SP (março de 2008 a maio de 2009).

\begin{tabular}{|c|c|c|c|c|}
\hline \multicolumn{5}{|c|}{ GRUPO AAA } \\
\hline Cultivares & $\begin{array}{c}\text { Textura } \\
\text { (N) }\end{array}$ & p H & $\begin{array}{c}\text { AT } \\
\text { (\% ác. málico) }\end{array}$ & $\begin{array}{c}\text { SS } \\
\left({ }^{\circ} \text { Brix) }\right.\end{array}$ \\
\hline Grand Naine & $9,99 \mathrm{~A}$ & $5,60 \mathrm{~A}$ & $0,21 \mathrm{~A}$ & $3,15 \mathrm{~B}$ \\
\hline Nanicão & $9,70 \mathrm{~A}$ & $5,54 \mathrm{~A}$ & $0,19 \mathrm{~A}$ & $2,71 \mathrm{~B}$ \\
\hline Caipira & $7,85 \mathrm{C}$ & $5,38 \mathrm{~A}$ & $0,25 \mathrm{~A}$ & 2,94 B \\
\hline Nam & $8,96 \mathrm{~B}$ & $5,55 \mathrm{~A}$ & $0,18 \mathrm{~A}$ & $6,33 \mathrm{~A}$ \\
\hline CV \% & 3,84 & 3,91 & 9,84 & 16,45 \\
\hline $\mathbf{F}$ & $37,04 *$ & $0,88 \mathrm{~ns}$ & $0,21 \mathrm{~ns}$ & $37,69 *$ \\
\hline \multicolumn{5}{|c|}{ GRUPO AAB } \\
\hline \multicolumn{5}{|l|}{ Cultivares } \\
\hline Thap Maeo & $7,44 \mathrm{~B}$ & $5,28 \mathrm{~B}$ & $0,18 \mathrm{~A}$ & $3,49 \mathrm{~A}$ \\
\hline Prata Anã & $9,70 \mathrm{~A}$ & $5,40 \mathrm{~B}$ & $0,14 \mathrm{AB}$ & $3,16 \mathrm{~A}$ \\
\hline Prata Zulu & $9,81 \mathrm{~A}$ & $5,94 \mathrm{~A}$ & $0,12 \mathrm{~B}$ & $3,42 \mathrm{~A}$ \\
\hline CV \% & 8,64 & 3,84 & 21,03 & 18,19 \\
\hline $\mathbf{F}$ & $12,62 *$ & $13,35^{*}$ & $4,94^{*}$ & $0,41 \mathrm{~ns}$ \\
\hline \multicolumn{5}{|c|}{ GRUPO AAAB } \\
\hline \multicolumn{5}{|l|}{ Híbridos } \\
\hline Fhia 01 & $8,50 \mathrm{~A}$ & $5,47 \mathrm{~A}$ & $0,20 \mathrm{~A}$ & $3,26 \mathrm{~A}$ \\
\hline Prata Graúda & $9,72 \mathrm{~A}$ & $5,73 \mathrm{~A}$ & $0,21 \mathrm{~A}$ & $2,80 \mathrm{~A}$ \\
\hline Fhia 18 & $9,03 \mathrm{~A}$ & $5,63 \mathrm{~A}$ & $0,13 \mathrm{~B}$ & $3,59 \mathrm{~A}$ \\
\hline Maçã Tropical & $8,70 \mathrm{~A}$ & $5,52 \mathrm{~A}$ & $0,12 \mathrm{~B}$ & $3,37 \mathrm{~A}$ \\
\hline CV \% & 9,48 & 4,55 & 14,67 & 18,06 \\
\hline $\mathbf{F}$ & $1,97 \mathrm{~ns}$ & $1,06 \mathrm{~ns}$ & $16,23 *$ & $1,6 \mathrm{~ns}$ \\
\hline \multicolumn{5}{|c|}{ GRUPO ABB } \\
\hline \multicolumn{5}{|l|}{ Cultivar } \\
\hline Figo Cinza & 8,13 & 6,23 & 0,07 & 3,48 \\
\hline
\end{tabular}

Médias seguidas pelas mesmas letras na coluna não diferem pelo teste de Tukey a 5\% de probabilidade 


\section{Grupo AAB}

'Prata Zulu' apresentou maior valor de $\mathrm{pH}(5,94)$, diferindo de 'Thap Maeo' e 'Prata Anã' que tiveram, respectivamente, valores de pH 5,28 e 5,4 (Tabela 06).

Segundo Ramos (2008), frutos verdes de 'Prata Zulu' apresentaram pH 6,0, 'Thap Maeo’ 5,36 e 'Prata Ana' 5,92. Damatto Júnior et al. (2005), observaram pH de 5,61 para frutos verdes de 'Prata Anã'. Para o mesmo cultivar em estádio verde de maturação, Gomes (2004) verificou pH referente a 5,86. Em frutos maduros de 'Thap Maeo' e 'Prata Anã', Botelho et al. (2002) constataram pH de 4,20 e 4,41, respectivamente. Pode-se observar que tanto no presente trabalho como nas citações, 'Thap Maeo' apresentou valores menores de $\mathrm{pH}$, o que pode caracterizar frutos mais ácidos, podendo ser destinados a indústria para a fabricação de doces.

\section{Grupo AAAB}

Como pode ser visualizado na Tabela 06, não foram observado diferenças entre os híbridos para valores de $\mathrm{pH}$. 'Fhia 01 ' apresentou $\mathrm{pH}$ correspondente a 5,47, 'Prata Graúda' 5,73, 'Fhia 18' 5,63 e 'Maçã Tropical' 5,52.

Ramos (2008) avaliando frutos dos mesmos híbridos não observou diferenças para valores de $\mathrm{pH}$, confirmando os resultados encontrados neste trabalho. Os autores verificaram para 'Fhia 01', 'Prata Graúda', 'Fhia 18' e 'Maçã Tropical' pH de 5,58, $5,54,5,34$ e 5,52, respectivamente.

Parrela et al. (2002) observaram que frutos verdes de 'Prata Graúda' apresentaram pH 5,69, 'Fhia 01' 5,61 e 'Fhia 18' 5,58. Santos et al. (2002) obtiveram valores de $\mathrm{pH}$ em frutos maduros de 'Prata Graúda' referentes a 4,60 e 4,33 em frutos de 'Fhia 18'. Botelho et al. (2002) encontraram para os mesmos híbridos valores de pH 4,19 e 4,22, respectivamente.

\section{Grupo ABB}

'Figo Cinza' apresentou pH 6,23 (Tabela 06). Ramos et al. (2009a), relataram para frutos verdes do mesmo cultivar $\mathrm{pH}$ de 6,06. Segundo Sgarbieri et al. (1965), o 
$\mathrm{pH}$ em frutos verdes de 'Figo' é igual a 5,80. Os valores alto de $\mathrm{pH}$ nas citações para 'Figo Cinza' confirmam o resultado observado neste trabalho.

Os resultados de $\mathrm{pH}$ para os frutos verdes encontrados neste trabalho não diferiram muito quando comparado as referências citadas, evidenciando que essa característica é intrínseca ao cultivar.

\subsubsection{Acidez Titulável (AT) \\ Grupo AAA}

Os valores de acidez titulável apresentados na Tabela 06 mostram que não houve diferença entre os cultivares. 'Grand Naine' apresentou frutos com teores de acidez titulável igual a $0,21 \%$, 'Nanicão' $0,19 \%$, 'Caipira' 0,25\% e 'Nam' 0,18\%.

O sabor dos frutos está relacionado aos teores de ácidos orgânicos da polpa, os quais são classificados como acidez titulável, sendo representados pelos teores de ácido málico em banana (PALMER, 1971). De acordo com Tuner (2001), a acidez é duplicada $\mathrm{e}$ às vezes triplicada com o amadurecimento do fruto.

Segundo Ramos (2008), frutos verdes dos cultivares Grand Naine, Nanicão, Caipira e Nam apresentaram, respectivamente, 0,18, 0,17, 0,14 e 0,14\% de acidez. Barbosa (2008) encontrou para frutos verdes de 'Nanicão', acidez referente a 0,19 \%, valor semelhante ao encontrado neste trabalho. Botelho et al (2002) observaram que a acidez de 'Caipira' foi de 0,46\%, 'Grand Naine' 0,34\% e 'Nanicão' 0,27\%. Cerqueira et al. (2002) verificaram que o cultivar Nam apresentou frutos com $0,19 \%$ e 0,28\% de acidez, respectivamente. De acordo com Santos et al. (2002) e Parrela et al. (2002), frutos de 'Caipira' apresentaram acidez de $0,35 \%$ e $0,23 \%$, respectivamente.

\section{Grupo AAB}

'Thap Maeo' apresentou frutos com teores mais altos de acidez $(0,18$ \%), porém não diferiu do cultivar Prata Anã, com acidez de 0,14\% (Tabela 06). 'Prata Zulu' apresentou frutos com menor acidez $(0,12 \%)$. Este valor está coerente com os valores de $\mathrm{pH}$, onde 'Prata Zulu' teve frutos com $\mathrm{pH}$ mais elevado $(5,94)$. 
Ramos (2008) constatou valores semelhantes ao avaliar os teores de acidez dos frutos dos cultivares Thap Maeo $(0,17 \%$, 'Prata Anã' $(0,13 \%)$ e 'Prata Zulu'(0,08\%),corroborando os resultados encontrados neste trabalho.

Os teores de acidez em frutos verdes de banana 'Prata' variam de 0,14 a 0,27\% (SGARBIERI et al. 1965; PINTO, 1978; CARVALHO, 1984). Os valores de acidez relatados neste trabalho estão dentro faixa indicada pelos autores. Damatto Júnior et al. (2005), avaliando frutos verdes do cultivar Prata Anã, verificaram acidez referente a 0,13\%. Para frutos verdes do mesmo cultivar, Gomes (2004), registrou acidez de 0,12\%. Em frutos maduros de 'Thap Maeo' e 'Prata Anã', Botelho et al. (2002) observaram 0,55\% e 0,48\% de acidez, estes valores são maiores do que os observados neste trabalho, fato que pode ser explicado pelas as diferentes condições de cultivo. Em regiões de clima frio os frutos tendem a ser mais ácidos.

\section{Grupo AAAB}

Os híbridos 'Fhia 01' e 'Prata Graúda' apresentaram frutos mais ácidos, sendo a acidez do primeiro de 0,20 \% e do segundo 0,21\%, não diferindo entre si. 'Fhia 18 ' e 'Maçã Tropical' também não diferiram entre si, apresentando acidez de 0,13\% e $0,12 \%$, respectivamente (Tabela 06 ).

Em Botucatu-SP, Ramos (2008) constatou que os frutos verdes de 'Fhia 01 ' apresentaram 0,18\% de acidez, 'Prata Graúda' 0,16\%, 'Fhia 18' e 'Maçã Tropical' tiveram acidez de 0,14\%. Parrela et al. (2002) avaliando a acidez de frutos dos híbridos 'Fhia 01', 'Prata Graúda' e 'Fhia 18' observaram valores correspondentes a 0,22\%, 0,21\% e 0,21\%, respectivamente. Segundo Santos et al. (2002), frutos com pontos amarelos de 'Fhia 18' apresentaram acidez de 0,44\% e 'Prata Graúda' 0,37\%. Entretanto, Alves et al. (2004), trabalhando com frutos dos mesmos híbridos, observaram, respectivamente acidez de 0,46\% e 0,41\%. Segundo Cerqueira et al. (2002), os frutos de 'Maçã Tropical' com sinais amarelos apresentaram 0,55\% de acidez e os frutos de 'Prata Graúda' apresentaram 0,48\%. 


\section{Grupo ABB}

'Figo Cinza' apresentou acidez de 0,06\%. Ramos et al. (2009a), trabalhando com o mesmo cultivar, encontrou valor semelhante ao deste trabalho $(0,06 \%)$. No entanto, Sgarbieri et al. (1965), observaram maiores valores para 'Figo', variando de 0,19\% para frutos verdes a $0,31 \%$ para frutos maduros.

\subsubsection{Sólidos Solúveis (SS)}

Segundo Kluge et al. (2002), o teor de sólidos solúveis indica a quantidade de açúcares existente no fruto, levando em consideração, embora em proporções reduzidas, a presença de outros compostos. Os ácidos, vitaminas, aminoácidos e algumas pectinas, também fazem parte deste composto.

\section{Grupo AAA}

Com menores teores de sólidos solúveis, 'Grand Naine', 'Nanicão' e 'Caipira' não diferiram entre si, apresentando, respectivamente, 3,15, 2,71 e 2,94 ${ }^{\circ} \mathrm{Brix}$ (Tabela 06). 'Nam' foi o cultivar que apresentou maiores teores de sólidos solúveis (6,33 ${ }^{\circ}$ Brix).

Os resultados deste trabalho confirmam os teores de sólidos solúveis encontrados por Ramos (2008), que avaliando a qualidade dos frutos de diferentes acessos de bananeira observou para 'Grand Naine' 3,73 'Brix, Nanicão 2,94 'Brix, 3,62 'Brix e 'Nam' 4,65 'Brix. Os autores também verificaram que 'Nam' apresentou maior teor de sólidos solúveis.

Sgarbieri et al. (1965) relataram que em frutos verdes de 'Nanicão' os teores de sólidos solúveis corresponderam a 0,78 ${ }^{\circ}$ Brix. Parrela et al. (2002) observaram para 'Caipira' 1,95 'Brix, valores inferiores aos encontrados neste trabalho. Essa diferença pode ocorrer devido ao estádio de maturação em que o fruto foi analisado. É sabido que em frutos mais verdes, os teores de sólidos solúveis são menores. Entretanto, Barbosa (2008), encontrou para os frutos verdes do cultivar Nanicão IAC, teor de sólidos solúveis referente a 3,0 ${ }^{\circ} \mathrm{Brix}$, valor próximo aos observados neste trabalho. 


\section{Grupo AAB}

Os teores de sólidos solúveis para todos cultivares foram semelhantes, não havendo diferença. Os frutos do cultivar Thap Maeo apresentaram 3,49 ${ }^{\circ}$ Brix, 'Prata Anã' 3,16 ${ }^{\circ}$ Brix e Prata Zulu 3,42 ${ }^{\circ}$ Brix (Tabela 06).

Segundo Ramos (2008), os frutos de 'Thap Maeo', 'Prata Anã' e 'Prata Zulu' apresentaram, respectivamente, teores de sólidos solúveis de 4,54 ${ }^{\circ}$ Brix, 3,63 ${ }^{\circ}$ Brix e $3,02{ }^{\circ}$ Brix.

De acordo com Sgarbieri et al. (1965), Pinto (1978) e Carvalho (1984), em frutos verdes de banana 'Prata' os teores de sólidos solúveis variam entre 0,92 a 3,40\%. Damatto Júnior et al. (2005), verificaram para frutos verdes de 'Prata Anã' teores de sólidos solúveis igual a $3,30^{\circ}$ Brix. Para o mesmo cultivar Gomes (2004) observou 3,20 ${ }^{\circ}$ Brix.

\section{Grupo AAAB}

Os híbridos não diferiram entre si, sendo que 'Fhia 01' apresentou 3,26 `Brix, 'Prata Graúda' 2,8 Brix, 'Fhia 18’ 3,59 Brix e 'Maçã Tropical' 3,37 ºrix (Tabela 06).

Ramos (2008) encontrou para frutos verdes dos mesmos híbridos teores de sólidos solúveis referentes a 3,84 ${ }^{\circ}$ Brix, $3,0^{\circ}$ Brix, 3,56 ${ }^{\circ}$ Brix e 2,96 ${ }^{\circ}$ Brix. Segundo Parrela et al. (2002), os frutos de 'Prata Graúda' apresentaram 2,70 Brix, 'Fhia 18' 2,13 Brix e 'Fhia $01^{\prime}: 1,87^{\circ}$ Brix.

\section{Grupo ABB}

'Figo Cinza' apresentou 3,48 'Brix (Tabela 06). Ramos et al. (2009a) encontraram teores de sólidos solúveis semelhantes para o mesmo cultivar (3,30 $\left.{ }^{\circ} \mathrm{Brix}\right)$. Sergabieri et al. (1965) observaram que em frutos verdes de 'Figo,' o teor de sólidos solúveis foi de $1,56^{\circ}$ Brix.

\subsubsection{Açúcares totais}

Segundo Konish et al. (1991), a degradação de amido é uma das características mais marcantes durante o processo de amadurecimento de frutos climatéricos. A medida que o amido é hidrolisado, percebe-se um incremento nos teores de açúcares 
solúveis totais que torna os frutos maduros e doces. Os principais açúcares encontrados na polpa da banana madura são glicose, frutose e sacarose (VILAS BOAS et al., 2001).

\section{Grupo AAA}

Os cultivares não diferiram entre si, sendo que 'Grand Naine' apresentou frutos com 0,51\% de açúcares totais, 'Nanicão' 0,44\%, 'Caipira' 0,57 \% e 'Nam' $0,32 \%$ (Tabela 07).

Ramos (2008) avaliando o teor de açúcares em frutos verdes de diferentes acessos de bananeira, observou que os cultivares Grand Naine, Nanicão, Caipira e Nam apresentaram teores referentes a 0,29\%,0,19\%,0,27\% e 0,17\%, taxas bem menores do que as verificadas neste trabalho.

\section{Grupo AAB}

'Prata Zulu' apresentou maiores teores de açúcares totais $(0,49 \%)$, diferindo de 'Prata Anã' e 'Thap Maeo', que apresentaram 0,37\% e 0,32\% (Tabela 07).

Em Botucatu, Ramos (2008), observou que 'Thap Maeo’ apresentou teor de açúcar de 0,46\%, 'Prata Anã' 0,30\% e 'Prata Zulu' 0,51\% O autor constatou que 'Prata Zulu' teve maior teor de açúcar quando comparado aos outros cultivares. Este trabalho confirma tais resultados. Segundo Sgarbieri et al. (1965) e Carvalho (1984), em frutos verdes de banana 'Prata' o teor de açúcar varia de 0,18 a 6,5\%. Os valores encontrados neste trabalho, estão dentro da faixa citada por estes autores.

\section{Grupo AAAB}

Os teores de açúcares nos frutos deste grupo variaram de 0,24\% para 'Fhia 01 ' e $0,60 \%$ para 'Fhia 18' (Tabela 07). 'Prata Graúda' não diferiu de 'Fhia 18'(0,42\%) e nem de 'Maçã Tropical' que apresentou 0,33\%.

Segundo Ramos (2008), os frutos verdes dos híbridos de 'Fhia 01', 'Prata Graúda', 'Fhia 18' e 'Maçã tropical' apresentaram teores de açúcares correspondentes a $0,26 \% 0,43 \%, 0,37 \%$ e $0,25 \%$, respectivamente. 


\section{Grupo ABB}

'Figo Cinza' apresentou 0,29\% de açúcares (Tabela 07). Ramos et al. (2009a) encontraram para esse mesmo cultivar valores inferiores $(0,15 \%)$.

\subsubsection{Amido}

\section{Grupo AAA}

Não foi observada diferença para os teores de amido. Os frutos de 'Grand Naine' apresentaram 28,25\%, 'Nanicão' 31,52\%, 'Caipira' 26,61\% e 'Nam' 39,88\% (Tabela 07).

Ramos (2008), avaliando o teor de amido em frutos verdes de 'Grand Naine', 'Nanicão', 'Caipira' e 'Nam', observou respectivamente, 13,45\%, 12,10\%, 12,04\% e 15,12\%. Sgarbieri et al. (1965) verificaram que os frutos verdes de 'Nanicão' apresentaram $11,95 \%$ de amido. Os teores de amido observado neste trabalho para os frutos dos mesmos cultivares foram superiores aos teores encontrados pelos autores, fato que se deve, provavelmente aos diferentes pontos de maturação em que os frutos foram analisados. Todavia, vale mencionar que os autores constataram que o cultivar Nam apresentou maior teor de amido, o que confirma o resultado observado na literatura citada.

\section{Grupo AAB}

Com base na Tabela 07, os frutos de 'Prata Graúda' apresentaram maiores teores de amido (34,40\%), diferindo de 'Thap Maeo' e 'Prata Anã', que apresentaram frutos com $25,98 \%$ e $29,68 \%$, respectivamente. 
Tabela 07. Valores médios de açúcares totais (AT), amido e teor de potássio (K) de frutos de acessos de bananeira, Botucatu-SP (março de 2008 a maio de 2009).

\begin{tabular}{|c|c|c|c|}
\hline \multicolumn{4}{|c|}{ GRUPO AAA } \\
\hline Cultivares & $\begin{array}{l}\text { AT } \\
(\%)\end{array}$ & $\begin{array}{c}\text { Amido } \\
(\%)\end{array}$ & $\begin{array}{c}\mathrm{K} \\
(\mathrm{gKg}-1)\end{array}$ \\
\hline Grand Naine & $0,51 \mathrm{~A}$ & $28,25 \mathrm{~A}$ & $5,44 \mathrm{~B}$ \\
\hline Nanicão & $0,44 \mathrm{~A}$ & $31,52 \mathrm{~A}$ & $5,73 \mathrm{AB}$ \\
\hline Caipira & $0,57 \mathrm{~A}$ & $26,61 \mathrm{~A}$ & $7,24 \mathrm{~A}$ \\
\hline Nam & $0,32 \mathrm{~A}$ & $39,88 \mathrm{~A}$ & $6,70 \mathrm{AB}$ \\
\hline $\mathrm{CV} \%$ & 31,01 & 28,74 & 14,41 \\
\hline $\mathbf{F}$ & $2,77 \mathrm{~ns}$ & $2,12 \mathrm{~ns}$ & $4,29 *$ \\
\hline \multicolumn{4}{|c|}{ GRUPO AAB } \\
\hline \multicolumn{4}{|l|}{ Cultivares } \\
\hline Thap Maeo & $0,32 \mathrm{~B}$ & $25,98 \mathrm{~B}$ & $4,93 \mathrm{~A}$ \\
\hline Prata Anã & $0,37 \mathrm{~B}$ & $29,68 \mathrm{AB}$ & $4,85 \mathrm{~A}$ \\
\hline Prata Zulu & $0,49 \mathrm{~A}$ & $34,4 \mathrm{~A}$ & $4,42 \mathrm{~A}$ \\
\hline CV \% & 17,13 & 16,26 & 19,04 \\
\hline $\mathbf{F}$ & $8,24^{*}$ & $3,74 *$ & $0,46 \mathrm{~ns}$ \\
\hline \multicolumn{4}{|c|}{ GRUPO AAAB } \\
\hline \multicolumn{4}{|l|}{ Híbridos } \\
\hline $\begin{array}{l}\text { Fhia } 01 \\
\end{array}$ & $0,24 \mathrm{C}$ & $28,43 \mathrm{~A}$ & $4,74 \mathrm{~A}$ \\
\hline Prata Graúda & $0,42 \mathrm{AB}$ & $33,59 \mathrm{~A}$ & $6,65 \mathrm{~A}$ \\
\hline Fhia 18 & $0,60 \mathrm{~A}$ & $33,98 \mathrm{~A}$ & $6,66 \mathrm{~A}$ \\
\hline Maçã Tropical & $0,33 \mathrm{BC}$ & $34,74 \mathrm{~A}$ & $5,84 \mathrm{~A}$ \\
\hline CV \% & 23,09 & 18,76 & 19,68 \\
\hline $\mathbf{F}$ & $13,76^{*}$ & $1,10 \mathrm{~ns}$ & $2,7 \mathrm{~ns}$ \\
\hline
\end{tabular}

\section{GRUPO ABB}

\section{Cultivar}

Figo Cinza

0,29

$35,01 \quad 5,20$

Médias seguidas das mesmas letras na coluna não diferem pelo teste de Tukey a 5\% de probabilidade.

Ramos (2008), em Botucatu, observou para frutos de 'Prata Zulu' valores de amido referentes a 18,27\%, 'Thap Maeo' 15,31\% e 'Prata Anã' 16,07\%. Damatto Júnior et al. (2005), relataram para frutos verdes de 'Prata Anã' 15\% de amido. Entretanto, Vilas Boas (1995) encontrou para os frutos dos mesmos cultivares, teores variando entre 15 a 
25 \%. Gomes (2004), verificou que os frutos de 'Prata' Anã' apresentaram 22, 17\% de amido. Os valores observados pelos dois últimos autores estão próximos dos encontrados neste trabalho.

\section{Grupo AAAB}

Os híbridos não diferiram entre si. 'Fhia 01 ' apresentou 28,43\%, 'Prata Graúda' 33,59\%, 'Fhia 18' 33,98\% e 'Maçã Tropical' 34,74\% (Tabela 07).

Segundo Ramos (2008), as médias dos teores de amido não diferiram entre si, onde 'Fhia 01', 'Prata Graúda', 'Fhia 18' e 'Maçã Tropical' apresentaram, respectivamente, 13,27\%,13,99\%,12,70\% e 14,20\%. A tendência observada pelos autores confirmam os resultados verificados neste trabalho, uma vez que também não foi observada diferença entre os cultivares.

\section{Grupo ABB}

Os frutos do cultivar Figo Cinza apresentaram 35,01\% de amido (Tabela 07). No entanto, Ramos et al. (2009a) encontraram valor inferior ao deste trabalho $(13,21 \%)$ e Sgarbieri et al. (1965) verificaram que frutos verdes de 'Figo' apresentaram 24,30 \% de amido. Como já mencionado anteriormente, essa variação nos teores de amido pode ser devido aos diferentes pontos de maturação em que os frutos foram analisados.

\subsubsection{Potássio}

Os sais minerais apresentam pequena variação durante a maturação do fruto, sendo que seus teores na banana verde são um pouco maiores do que na banana madura (BLEINROTH, 1990). Segundo o mesmo autor, a concentração de potássio na banana madura é de 350 a $400 \mathrm{mg} .100 \mathrm{~g}^{-1}$ de matéria seca, o que equivale a 0,35 a $0,40 \%$. 


\section{Grupo AAA}

Os teores de potássio nos frutos dos cultivares pertencentes a este grupo variaram de 5,44 g. $\mathrm{Kg}^{-1}$ para 'Grand Naine' a 7,24 g. $\mathrm{Kg}^{-1}$ para 'Caipira'(Tabela 07). 'Nanicão' e 'Nam' apresentaram valores intermediários 5,73 e 6,7 g Kg-1 respectivamente.

Ramos (2008) constatou que em frutos verdes de 'Grand Naine', os teores de potássio foram de 3,03 g. $\mathrm{Kg}^{-1}$, 'Nanicão' 2,97 g. $\mathrm{Kg}^{-1}$ 'Caipira' 3,41 g. $\mathrm{Kg}^{-1} \mathrm{e}$ 'Nam' 3,25 g. $\mathrm{Kg}^{-1}$. Os teores de potássio encontrados neste trabalho são superiores aos observados pelos autores.

\section{Grupo AAB}

Os cultivares deste grupo não apresentaram diferença nos teores de potássio dos seus frutos. Os frutos de 'Thap Maeo', 'Prata Anã' e 'Prata Zulu' apresentaram 4,93 g. Kg ${ }^{-1}$, 4,85 g. $\mathrm{Kg}^{-1}$ e 4,42 g. $\mathrm{Kg}^{-1}$ de potássio, respectivamente (Tabela 07).

Em Botucatu-SP, Ramos (2008) relatou que frutos verdes de 'Thap Maeo' e 'Prata Anã' apresentaram 3,39 g. $\mathrm{Kg}^{-1}$ e de 'Prata Zulu' 2,78 g. $\mathrm{Kg}^{-1}$

\section{Grupo AAAB}

'Os híbridos não diferiram entre si, sendo que 'Fhia 01' apresentou 4,74 g, Kg ${ }^{-1}$, 'Prata Graúda' 6,65 g. $\mathrm{Kg}^{-1}$, 'Fhia 18' 6,66 g. $\mathrm{Kg}^{-1}$ e 'Maçã Tropical' 5,84 g. $\mathrm{Kg}^{-1}$. Segundo Ramos (2008), os mesmos híbridos apresentaram, respectivamente, 2,92 g. $\mathrm{Kg}^{-1}, 3,22 \mathrm{~g} \cdot \mathrm{Kg}^{-1}, 2,91 \mathrm{~g} \cdot \mathrm{Kg}^{-1}$ e $3,36 \mathrm{~g} \cdot \mathrm{Kg}^{-1}$.

\section{Grupo ABB}

Os frutos do cultivar Figo Cinza apresentaram teor de potássio correspondente a 5,2 $\mathrm{g} \mathrm{Kg}^{-1}$ (Tabela 07). Entretanto, para o mesmo cultivar, Ramos et al. (2009a) observaram 2,98 g. $\mathrm{Kg}^{-1}$. 


\subsubsection{Análise sensorial}

\section{Grupo AAA}

Com base na Figura 06, não foram observadas diferenças entre os cultivares para o atributo aparência. Em relação ao aroma, o cultivar Nanicão apresentou maior média $(7,16)$, diferindo de 'Nam' e 'Caipira'. 'Grand Naine' não diferiu de nenhum dos cultivares. 'Nanicão' e 'Grand Naine' diferiram do cultivar 'Caipira' no que diz respeito ao atributo textura, mas 'Nam' apresentou média intermediária, não diferindo de nenhum dos cultivares. Para o atributo sabor, 'Caipira' obteve menor média $(5,54)$, diferindo de 'Grand Naine', 'Nanicão' e 'Nam' que tiveram maior aceitação, apresentando médias que variaram entre 6,86 e 6,9 ("gostei ligeiramente"). A avaliação global é um atributo em que o provador avalia o produto atribuindo uma nota geral. Nesse atributo, 'Grand Naine' e 'Nanicão' apresentaram maiores médias: 7,28 e 7,14 ("gostei regularmente") respectivamente, diferindo de 'Caipira' que obteve média igual a 6,0 e 'Nam' que com média correspondente a 6,56 não diferiu de nenhum dos cultivares.

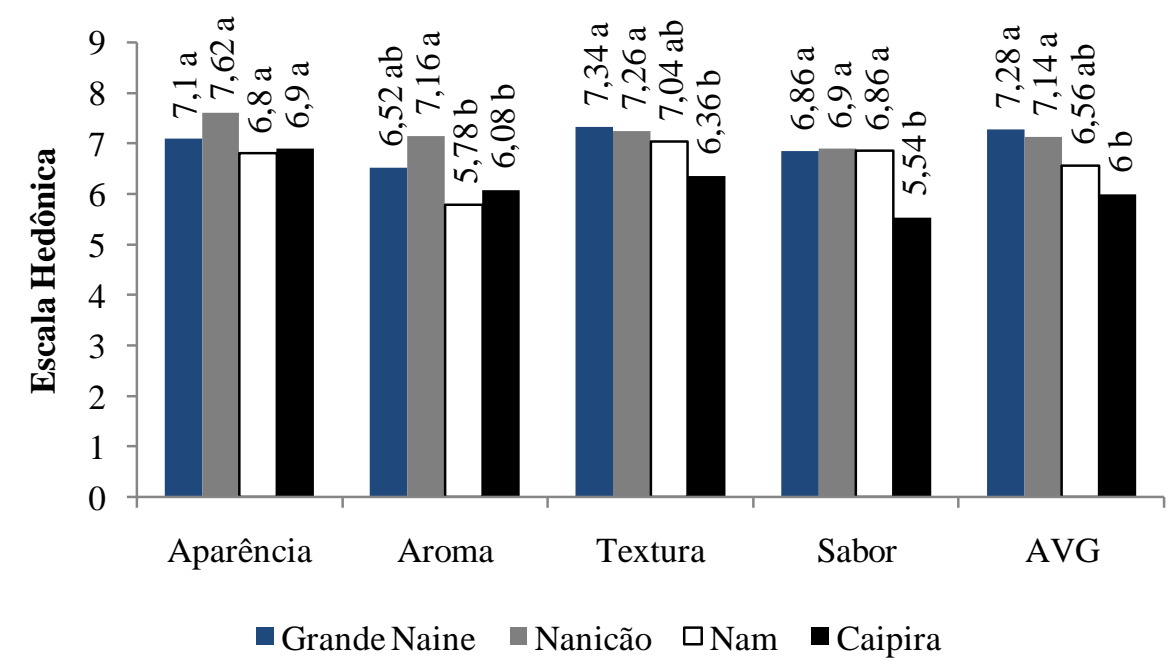

Médias seguidas da mesma letra em cada atributo, não diferem significativamente a nível de 5\%, pelo teste de Tukey.

Figura 06. Atributos de aparência, aroma, textura, sabor e AVG (avaliação global) da polpa dos frutos de genótipos de bananeira do grupo AAA, FCA/UNESP-Botucatu-SP/2009. 
$\mathrm{Na}$ análise sensorial, o sabor é um dos principais atributos, pois reflete a preferência do consumidor pelo produto. Considerando esta afirmação, neste grupo, Caipira foi o cultivar menos aceito por parte dos provadores. Matsuura et al. (2002), avaliando as características sensoriais de sete acessos de bananeira, verificaram que o cultivar Caipira também apresentou menor nota, sendo portanto o cultivar menos aceito.

\section{Grupo AAB}

O resultado da análise sensorial mostrou que não houve diferença entre os cultivares para os atributos aroma, sabor e avaliação global (Figura 07). As médias variaram de 6,68 para 7,32, indicando boa aceitação por parte dos provadores. Entretanto, para os atributos aparência e textura, o cultivar Prata Zulu foi o menos aceito, com média 7,1 para o primeiro atributo e 7,0 para o segundo. 'Thap Maeo' e 'Prata Zulu' obtiveram médias aproximadas para os dois atributos, não diferindo entre si.

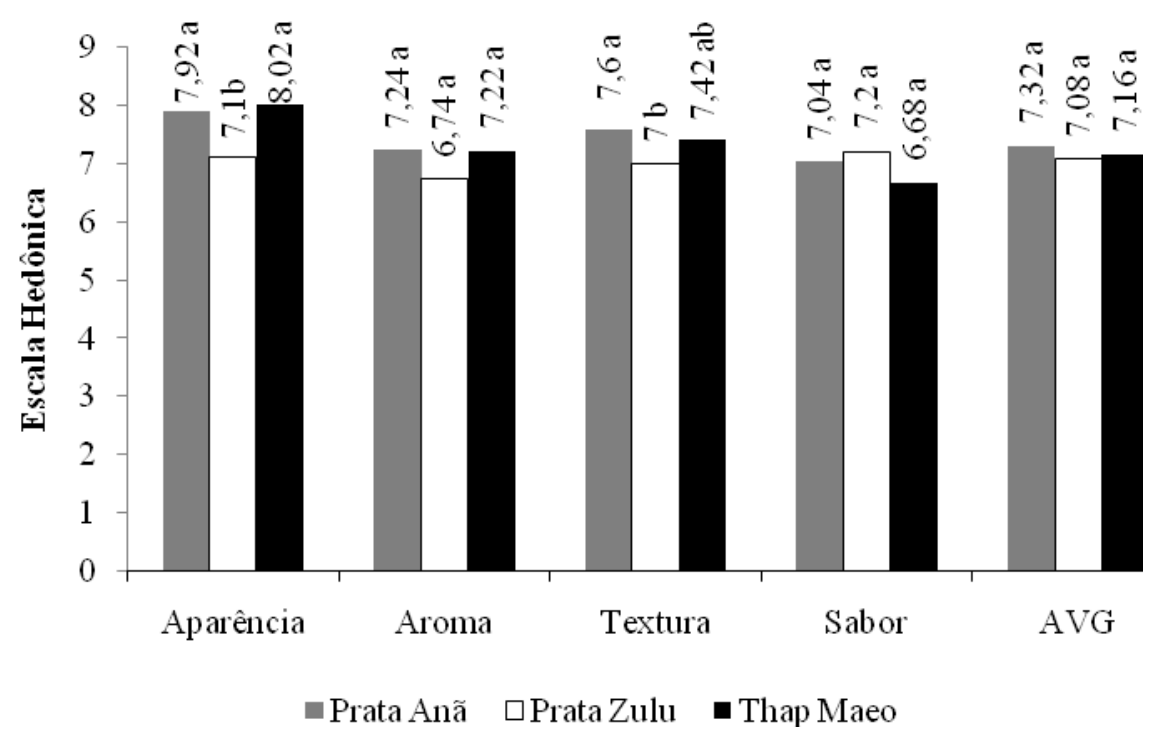

Médias seguidas da mesma letra em cada atributo, não diferem significativamente a nível de 5\%, pelo teste de Tukey.

Figura 07. Atributos de aparência, aroma, textura, sabor e AVG (avaliação global) da polpa dos frutos de genótipos de bananeira do grupo AAB, FCA/UNESP-Botucatu-SP/2009. 
Para Matsuura et al. (2002), a cor ou aparência por estarem ligadas à atratividade para o consumidor, é um atributo importante na análise sensorial. Nesse contexto, o cultivar Prata Zulu foi o menos aceito. Damatto Júnior et al. (2005), avaliando a aceitação sensorial dos cultivares Prata Anã e Prata Zulu, verificaram que os provadores tiveram preferência pelo cultivar Prata Anã. Segundo os autores, essa preferência se deve ao fato de os consumidores já estarem habituados a este cultivar.

\section{Grupo AAAB}

No grupo dos híbridos, 'Prata Graúda' obteve maior média para o atributo aparência $(8,1)$, diferindo de 'Fhia 01' e 'Maçã Tropical' (Figura 08). 'Fhia 18' não diferiu de 'Fhia 01,' e esta por sua vez não diferiu de 'Maçã tropical'.

Em relação aos atributos aroma e textura, os híbridos apresentaram comportamento semelhante, onde 'Fhia 01' e 'Maçã Tropical' apresentaram as menores médias, diferindo de 'Prata Graúda' (Figura 08). 'Fhia 18' não diferiu de nenhum dos cultivares.

Os híbridos 'Fhia 01' e 'Maçã Tropical' apresentaram menores médias para o atributo sabor (6,56 e 6,54, respectivamente), diferindo de 'Prata Graúda' e 'Fhia 18' que com maiores médias, não diferiram entre si, sendo considerados os cultivares mais aceitos pelos provadores.

$\mathrm{Na}$ avaliação geral, 'Prata Graúda' foi o híbrido mais preferido pelos provadores, apresentando média referente a 8,06, seguida de 'Fhia 18' com média 7,5 que não diferiu de nenhum dos cultivares. As menores médias foram observadas para os híbridos 'Fhia 01' e 'Maçã Tropical'(6,86 e 6,66, respectivamente). 


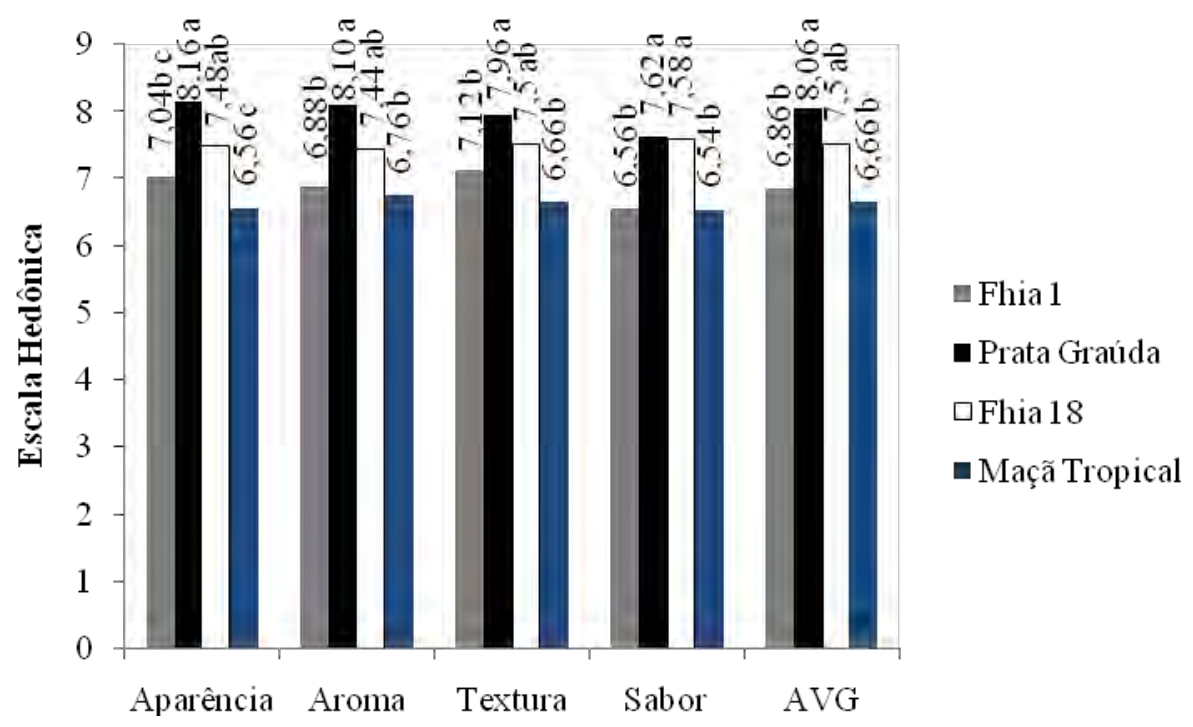

Médias seguidas da mesma letra em cada atributo, não diferem significativamente a nível de 5\%, pelo teste de Tukey.

Figura 08. Atributos de aparência, aroma, textura, sabor e AVG (avaliação global) da polpa dos frutos de genótipos de bananeira do grupo AAAB, FCA/UNESP-Botucatu-SP/2009.

Para a maioria dos atributos avaliados, o híbrido 'Prata Graúda' teve melhor aceitação, apresentando valores próximos ou igual a 8 ("gostei moderadamente"), para o atributo sabor, este híbrido teve preferência semelhante ao 'Fhia 18' por parte dos provadores. Matssura et al. (2002) avaliaram durante dois anos a aceitação sensorial de sete acessos de bananeira e verificaram que o híbrido 'Prata Graúda' foi o mais preferido pelos provadores. Pereira et al. (2002) encontraram resultados semelhantes ao avaliar o índice de aceitação de novos acessos de bananeira, observando que 'Prata Graúda' teve maior aceitação. Os resultados do presente trabalho confirmam os observados na referência citada trabalho.

\section{Grupo ABB}

'Figo Cinza' apresentou menores médias quando comparado aos demais acessos (Figura 09). Os provadores deram as menores notas para os atributos sabor e avaliação geral: 5,0 e 5,14, respectivamente. A explicação para este fato é que este cultivar, na maioria das regiões do país é consumido na forma cozida ou frita, fazendo com que os provadores tenham certa rejeição pelo consumo ao natural. 


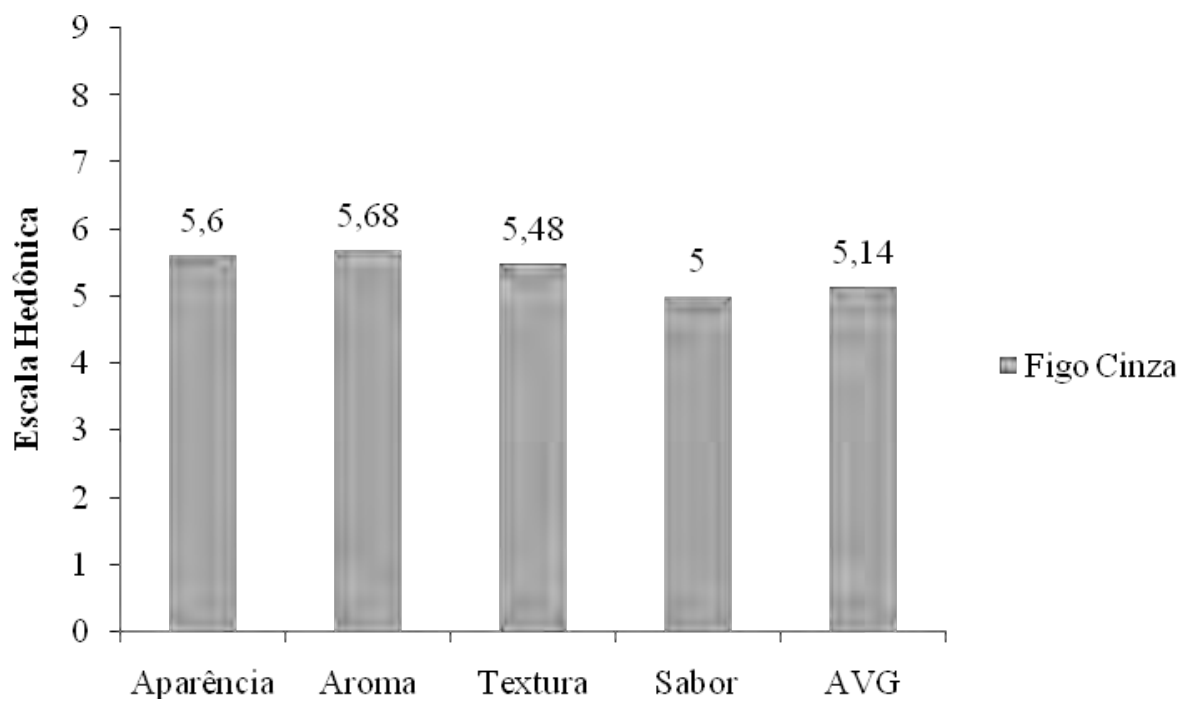

Figura 09. Atributos de aparência, aroma, textura, sabor e AVG (avaliação global) da polpa dos frutos do cultivar de bananeira do grupo ABB, FCA/UNESP-Botucatu-SP/2009.

De forma geral, as médias para 'Figo Cinza' variaram entre 5,0 e 5,68, o que corresponde na escala hedônica a um resultado indiferente ("nem gostei nem desgostei").

As amostras dos frutos servidos aos provadores apresentaram valores considerados normais para frutos maduros (Tabela 08), com textura variando de 0,15 a 0,42 N, pH de 4,16 a 5,52, acidez titulável de 0,29 a 0,64\% e teor de sólidos solúveis de 20,27 a 26,4 ${ }^{\circ}$ Brix, os quais são concordantes aos encontrados por SOTO BALLESTERO(1992) \& BLEINROTH( 1995). 
Tabela 08. Valores médios de textura, pH, AT (acidez titulável) e sólidos solúveis da polpa de frutos de acessos de bananeira Botucatu-SP ( março de 2008 a maio de 2009).

\begin{tabular}{lcccc}
\hline Acessos & $\begin{array}{c}\text { Textura* } \\
(\mathrm{N})\end{array}$ & $\mathrm{pH}^{*}$ & $\begin{array}{c}\mathrm{AT}^{*} \\
\text { (\% ác. málico) }\end{array}$ & $\begin{array}{c}\text { SS* } \\
\left.\text { ( }{ }^{\circ} \text { Brix }\right)\end{array}$ \\
\hline Grand Naine & 0,34 & 5,10 & 0,58 & 25 \\
Nanicão & 0,42 & 5,15 & 0,34 & 20,27 \\
Caipira & 0,28 & 5,52 & 0,29 & 23,07 \\
Nam & 0,26 & 4,89 & 0,57 & 22,93 \\
Thap Maeo & 0,19 & 4,35 & 0,44 & 22,6 \\
Prata anã & 0,41 & 4,44 & 0,46 & 23,5 \\
Prata Zulu & 0,20 & 4,19 & 0,39 & 26,4 \\
Fhia 01 & 0,15 & 4,42 & 0,41 & 22,17 \\
Prata Graúda & 0,29 & 4,59 & 0,48 & 21,77 \\
Fhia 18 & 0,32 & 4,68 & 0,35 & 20,37 \\
Maçã Tropical & 0,25 & 4,57 & 0,41 & 21,43 \\
Figo Cinza & 0,40 & 4,16 & 0,64 & 23,73 \\
\hline
\end{tabular}

*Médias de 3 repetições 


\section{CONSIDERAÇÕES FINAIS}

Sabe-se que ainda não há no mercado um acesso de bananeira perfeito. Sendo assim, procurou-se escolher de cada grupo genômico, aquele (s) acessos que reunissem o maior número de características desejadas.

No grupo AAA, 'Grand Naine' apresentou boas características de crescimento, produção e boa aceitação, porém teve ciclo longo. 'Nanicão' apresentou boas características de crescimento, produção, qualidade e boa aceitação. 'Caipira' destacou-se apenas nos teores de potássio. 'Nam' apresentou porte baixo, ciclo curto e maior teore de açúcares, entretanto, mostrou-se pouco produtiva.

No grupo AAB, 'Thap Maeo' apresentou menor ciclo, maior número de frutos por cacho, porém apresentou porte alto. 'Prata Anã' apresentou porte mais baixo e frutos com boa firmeza. O cultivar Prata Zulu apresentou frutos com maiores teores de açúcares e amido, baixa acidez, boa firmeza, mas apresentou porte alto.

Em relação ao grupo $\mathrm{AAAB}$, o hibrido 'Fhia 01' apresentou boas características de produção, porém baixa aceitação. 'Prata Graúda' apresentou boas características de produção e melhor aceitação. 'Fhia 18' teve boa produção, maiores teores de açúcares e boa aceitação. 'Maçã Tropical' apresentou o menor ciclo. 'Figo Cinza', do grupo $\mathrm{ABB}$, apresentou frutos menos ácidos, porém apresentou ciclo longo, porte elevado e baixo potencial produtivo, com aceitação indiferente pelos provadores. 
Uma das constatações relevantes neste trabalho foi que houve variação no número de dias da emissão da inflorescência até a colheita para os diferentes grupos genômicos. Com isso, uma alternativa para o produtor é fazer escalonamento, tendo em sua propriedade acessos de bananeira de diferentes grupos genômicos, produzindo o ano inteiro e podendo ainda diversificar a oferta no mercado. 


\section{CONCLUSÕES}

Considerando os acessos que tiveram melhor desempenho agronômico, qualidade e aceitação sensorial, conclui-se que:

No grupo genômico AAA, os acessos que se destacaram foram 'Grand Naine' e 'Nanicão', no grupo AAB foi o cultivar Prata Zulu e no grupo AAAB, o melhor híbrido foi o 'Prata Graúda'.

'Figo Cinza' apresentou porte elevado, baixo potencial produtivo, frutos com baixa acidez e aceitação sensorial indiferente. 


\section{REFERÊNCIAS BIBLIOGRÁFICAS}

ANUÁRIO BRASILEIRO DA FRUTICULTURA. Santa Cruz do Sul, Ed. Gazeta Santa Cruz 2009. $136 \mathrm{p}$.

ALVES, E. J. Principais cultivares de banana no Brasil. Revista Brasileira de Fruticultura, Cruz das Almas, v. 12, n. 3, p. 45-61, jan. 1990.

ALVES, E.J.; MEDINA,W.M.; OLIVEIRA, M. de A. Colheita e manejo pós-colheita. In. ALVES, E.J. (ed.). A cultura da banana. Aspectos técnicos, sócioeconômicos e agroindustriais. 2 ed. Brasília-DF; EMBRAPA-SP, 1999. p. 453-486.

ANDRADE, G. M. et al. Avaliação de genótipos de bananeira no estado do Piauí: comportamento vegetativo. In: CONGRESSO BRASILEIRO DE FRUTICULTURA, 17. 2002, Belém. Anais... Belém: SBF, 2002. 1 CD-ROM.

ASSOCIATION OF OFFICIAL ANALYTICAL CHEMIST. Official methods of analysis of the association of official analytical chemist. $11^{\text {th }}$ ed. Washington, 1970. $1015 \mathrm{p}$.

BARBOSA, R. D. Manejo do solo com lodo de esgoto em bananeira irrigada. $2008.84 \mathrm{f}$. Tese (Doutorado em Agronomia/Irrigação e Drenagem)-Faculdade de Ciências Agronômicas, Universidade Estadual Paulista, Botucatu-SP. 
BLEINROTH, E. W. Matéria-prima. In: Medina, j. c. et al. Banana: cultura, material-prima, processamento e aspectos econômicos. 2 ed. rev. e ampl. Campinas: ITAL, 1990. P. 179-196. (Série frutas tropicais, 3).

BLEINROTH, E. W. Matéria-Prima. In: INSTITUTO DE TECNOLOGIA DE

ALIMENTOS. Banana - Matéria-Prima, processamento e aspectos econômicos. 2.ed. Campinas: ITAL, p.133-196, 1995.

BORGES, A. L.; OLIVEIRA, A.M.G. Nutrição, calagem e adubação. In: COREDEIRO, A.J.M. Banana produção: aspectos técnicos. Brasília: Embrapa Comunicação para Transferência de Tecnologia, 2000. P.47-59 (Série Frutas do Brasil, 1)

BORGES, A. L. et al. A cultura da Banana. $2^{\circ}$ ed. rev. e aum. Brasília: Embrapa - SPI , 1998. 94 p. (Coleção Plantar, 38).

BOTELHO, M. A. P. et al. Avaliação de genótipos de bananeira no estado do Piauí: qualidade de fruto. In: congeresso brasileiro de fruticultura, 17., 2002, Belém. Anais... Belém: SBF, 2002. 1 CD-ROM.

BRECHBUELBER, A. J. M. M.; COUTO, F. A. A. Avaliação do comportamento agronômico da bananeira (Musa spp) cv. 'Nanicão' e 'Prata-anã' na microrregião de Viçosa, Minas Gerais. In: CONGRESSO BRASILEIRO DE FRUTICULTURA, 14., 1996, Curitiba.

Anais...Sociedade Brasileira de Fruticultura: 1996. p. 74.

CARVALHO, H. A. de. Qualidade de banana 'Prata' previamente armazenada em saco de polietileno, amadurecida em ambiente com elevada umidade relativa. $92 \mathrm{f}$. Dissertação (Mestrado em Ciências dos Alimentos) Escola Superior de Agricultura de Lavras, Lavras, 1984.

CEAGESP. Classificação da banana. São Paulo, 1998. 1 Folder.

CERQUEIRA, R. C.; SILVA, S. DE O.; MEDINA, V. M. Características pós-colheita de frutos de genótipos de bananeira (Musa spp.). Revista Brasileira de Fruticultura, Jaboticabal, v. 24, n. 3, p. 654-657, dez. 2002. 
CHAMPION, J. El plátano: técnicas agrícolas y producciones tropicales. Barcelona: Blume, 1975. p. 50.

CHITARRA, M.I.F.; CHITARRA, A.B. Pós-colheita de frutos e hortaliças: fisiologia e manuseio. Lavras: ESAL-FAEPE,1990. 320 p.

CHITARRA, M. I. F. Tecnologia e qualidade pós-colheita de frutos e hortaliças. Lavras: UFLA/FAEPE, 2000. 68p.

CORDEIRO, Z. J. M. Cultivo da bananeira para o Estado de Rondônia: cultivares. Cruz das Almas: EMBRAPA, CNPTIA, 2003. Disponível em

http://sistemasdeproducao.cnptia.embrapa.br/FontesHTML/Banana/BananaRodonia/index.htm . Acesso em 15 jul 2008

CUNHA, A. R. et al. Classificação climática para o município de Botucatu, SP, segundo Köppen. In: SIMPÓSIO EM ENERGIA NA AGRICULTURA, 1., 1999, Botucatu. Anais... Botucatu: Faculdade de Ciências Agronômicas, 1999. p. 490-491.

DADZIE, B. K.; ORCHARD. J. E. Evaluación rutinaria postcosecha de híbridos de bananos y plátanos: criterios y métodos. Roma, Itália.CIRPAC. IPGRI, 1997. p.63. (Guias técnicas Inibap 2).

DAMATTO JUNIOR, E.R. Efeitos da adubação com composto orgânico na fertilidade do solo, desenvolvimento, produção e qualidade de frutos de bananeira 'Prata-anã' (Musa AAB). 2005. 70f. Dissertação (Mestrado em Agronomia / Energia na Agricultura). Faculdade de Ciências Agronômicas, Universidade Estadual Paulista, Botucatu, 2005.

DAMATTO JUNIOR, E.R. et al. Produção e caracterização de frutos de bananeira 'PrataAnã' e 'Prata Zulu'. Revista Brasileira de Fruticultura, Jaboticabal, v. 27, n. 3, p. 440-443, dez. 2005.

DAMATTO JUNIOR, E.R. Adubação orgânica da bananeira Prata Anã e experiências com outras cultivares nas Ilhas Canárias. 2008. 112f. Tese (Doutorado em Agronomia / Horticultura). Faculdade de Ciências Agronômicas, Universidade Estadual Paulista, Botucatu, 2008. 
DANTAS, J.L.L.; SOARES FILHO, W. S. Classificação botânica, origem e evolução. In: ALVES et al. (Eds), Banana para exportação: aspectos técnicos da produção. Cruz das Almas: MAARA-SDR-BA/EMBRAPA-SPI; 1995. p.9-13. (FRUPEX.Publicações Técnicas, 18)

DANTAS, J. L.L. ; FILHO, W. dos S. S. Classificação botânica, origem e evolução. In: ALVES, E. J. (Org.). Banana para exportação: aspectos técnicos de produção. 2. ed. rev. Brasília, DF: EMBRAPA, SPI, 1997. p. 9-13. (Série publicações técnicas Frupex, 18).

DANTAS, J. L.L. et al. Citogenética e melhoramento genético. In: ALVES, E. J. (Org.). A cultura da banana: aspectos técnicos sócioeconômicos e agroindustriais. 2. ed. rev. Brasília, DF: EMBRAPA, SPI, 1999. p.136.

DONATO, S. L. R. et al. Avaliação de variedades e híbridos de bananeira sob irrigação. Revista Brasileira de Fruticultura, Jaboticabal, v. 25, n. 2, p. 348-351, ago. 2003.

DONATO, S. L. R. et al. Comportamento de variedades e híbridos de bananeira (Musa spp.), em dois ciclos de produção no sudoeste da Bahia. Revista Brasileira de Fruticultura, Jaboticabal, v. 28, n. 1, p. 139-144, abr. 2006.

EMBRAPA. Centro Nacional de Pesquisa de Solos. Sistema Brasileiro de Classificação de Solos. 2. ed. Rio de Janeiro: EMBRAPA SOLOS, 2006. 306 p.

FANCELLI, M. Cultivo da bananeira para o Estado do Amazonas: cultivares: EMBRAPA,CNPTIA,2003.Disponívelemhttp://sistemasdeproducao.cnptia.embrapa.br/Fontes HTML/Banana/BananaAmazônia/index.htm. Acesso em 15 jul 2008.

FAO. Disponível em: <http://faostat.fao.org/site/567/DesktopDefault,aspx?Page|D = 567> . Acesso em: 31 jan. 2008.

FERNANDES, K. M.; CARVALHO, V. D. de;CAL-VIDAL, J. Physical changes during ripening of silver bananas. Journal of Food Science, Chicago, v. 44, n. 4, p. 1254-1255, 1979. 
FOLTRAN, D. E. et al. Comportamento de sete cultivares de bananeira no Oeste Paulista. In: CONGRESSO BRASILEIRO DE FRUTICULTURA, 15., 1998, Poços de Caldas-MG, Resumos... Lavras. UFLA/SBF, 1998. p. 127.

GAIVA, H. N. Avaliação de algumas características do desenvolvimento e da produção de três cultivares de bananeira (musa spp), na baixada cuiabana - MT. 1992. 103 f. Tese (Doutorado em Produção vegetal) - Faculdade de Ciências Agrárias e Veterinárias, Universidade Estadual Paulista, Jaboticabal,1992.

GANGA, R. M. D. et al.Avaliação de seis cultivares de bananeira em Jaboticabal-SP. In: CONGRESSO BRASILEIRO DE FRUTICULTURA, 17., 2002, Belém. Anais... Belém: SBF, 2002. 1 CD-ROM.

GOMES, E. M. Crescimento e produção de bananeiras 'Prata Anã' e 'Maçã' fertirrigadas com potássio. 2004.76 f. Tese (Doutorado em Agronomia)- Faculdade de Ciências Agronômicas, Universidade Estadual Paulista, Botucatu, 2004.

GONÇALVES, V. D.; NIETSCHE, S.; PEREIRA, M .C .T.; SILVA, S. O.; SANTOS, T. M. dos.; OLIVEIRA, J.R.; FRANCO, L. R. L.; RUGGIERO, C. Avaliação dos cultivares de bananeira prata-anã, thap maeo e caipira em diferentes sistemas de plantio no norte de minas gerais. Revista Brasileira de Fruticultura, Jaboticabal, v. 30, n. 2, p. 371-376, jun. 2008.

GONZAGA NETO, L. et al. Avaliação de cultivares de bananeira na região do submédio São Francisco: primeiro ciclo de produção. Revista Brasileira de Fruticultura, Cruz das Almas, v. 15, n. 1, p. 21-25, 1993.

IBGE 2008. Disponível em <http://www.sidra.ibge.gov.br/bda/tabela/protabl.asp>. Acesso em: 25 jan. 2008.

INSTITUTO ADOLFO LUTZ. Métodos químicos e físicos para a análise de alimentos. 3.ed. São Paulo: Instituto Adolfo Lutz, 1985. 553 p.

KIEBER, J. Etileno: o hormônio gasoso. In: TAIZ, L.; ZEIGER, E. (Eds). Fisiologia vegetal. $3^{\mathrm{a}}$ ed. Porto Alegre: ARTMED Ed., 2004. P.541-559. 
KLUGE, R. A. et al. Fisiologia e manejo pós-colheita de frutas de clima temperado. 2 ed. rev. e ampl. Campinas: Rural, 2002. 214 p.

KONISH,Y.; KITAZATO, S.; ABANO, R. Polymorphism of acid and neutral y-glucosidades in banana pulp. Changes in apparent pIs an affitity to Com A of the enzymes during ripening. Agricultura Biological Chemistry, Tokyo, v. 55, n. 4, p. 1089-1094, Apr. 1991.

LAL, R.K.; GARG, M.; KRISHNAN, P. S. Biochemical aspects of the developing and ripening banana. Phytochemistry, New York, v.13, n.11, p.2365-2370, 1974.

LEDO, A. S.; SILVA, S. O.; AZEVEDO, F. F. Avaliação preliminar de genótipos de banana (Musa spp.) em Rio Branco (AC). Revista Brasileira de Fruticultura, Cruz das Almas, v. 19, n. 1, p. 51-56, abr. 1997.

LEDO, A. S. et al. Avaliação de genótipos de bananeira na região do Baixo São Francisco, Sergipe. Revista Brasileira de Fruticultura, Jaboticabal, v. 30, n.3, p. 691-695, set. 2008.

LEITE, J. B. V. et al. Caracteres da planta e do cacho de genótipos de bananeira, em 4 ciclos de produção, em Belmonte, Bahia. Revista Brasileira de Fruticultura, Jaboticabal, v. 25, n.3, p. 443-447, dez. 2003.

LEONEL, S.; GOMES, E. M.; PEDRO, D. J. Desempenho Agronômico de Bananeiras micropropagadas em Botucatu-SP. Revista Brasileira de Fruticultura, Jaboticabal, v. 26, n. 2, p. 245-248, ag. 2004.

LIMA, M. B. et al. Avaliação de cultivares e híbridos de bananeira no recôncavo baiano. Ciência Agrotecnologia, Lavras, v. 29, n. 3, p. 515-520, maio/jun. 2005.

MAlAVOLTA, E.; VITTI, G. C.; OLIVEIRA, S. A. de. Avaliação do estado nutricional das plantas: princípios e aplicações. 2. ed. rev. e atual. Piracicaba: Potafos, 1997.319 p.

MATSUURA, F. C. A. U.; CARDOSO, R. L.; RIBEIRO, D. E. Qualidade sensorial de frutos híbridos de bananeira cultivar Pacovan. Revista Brasileira de Fruticultura, Jaboticabal, v.24, n.1, p.263-266, 2002. 
MATSUURA, F.C.A.U.; COSTA, J.I.P. DA; FOLEGATTI, M.I. DA S. Marketing de banana: preferências do consumidor quanto aos atributos de qualidade dos frutos. Revista Brasileira de Fruticultura, Jaboticabal, v.26, n.1, p.48-52, 2004.

MERCADO. Mercado internacional está aberto às nossas frutas. Jornal da OCEMG, Belo Horizonte, fev, 1997. v. 6, n. 68, p. 5.

MORAES, M. A. C. Métodos para a avaliação sensorial dos alimentos.7.ed. Campinas: Unicamp, 1988. 93p.

MOREIRA, R. S. Banana: teoria e prática de cultivo. Campinas: Fundação Cargill, 1987. 335 p.

MOREIRA, R. S. Banana: teoria e prática de cultivo. 2. ed. São Paulo: Fundação Cargill, 1999. CD-ROM.

MOREIRA, R. S. Nossa Nanica está garantida. Revista Rural, n. 63, mar. 2003. Disponível em www.revistarural.com.br/Edições/2003/Artigos/rev63_nanica.htm. Acesso em: 30 ag. 2005.

NELSON, N. A. A photometric adaptation of Somogy method for the determination of Glucose. Journal Biological Chemistry, v. 153, p. 375-80, 1944.

OLIVEIRA, C. A. P. de.et al. Genótipos de bananeira em três ciclos na zona da mata mineira. Pesquisa Agropecuária Brasileira, Brasília, DF, v. 42, n.2 p. 173-181 fev. 2007.

OLIVEIRA, T. K. de. et al. Características agronômicas de genótipos de bananeira em três ciclos de produção em Rio Branco, AC. Pesquisa Agropecuária Brasileira, Brasília, DF, v. 43, n.8 p. 1003-1010 ago. 2008.

PALMER, J. K. The banana. In: HULME, A. C. (Ed.). The biochemistry of fruits and their products. London: Academic Press, 1971. v. 2, p. 65-105.

PARRELA, R. A. da C. et al. Caracterização físico química dos frutos de genótipos de bananeira produzidos no Norte de Minas. In: CONGRESSO BRASILEIRO DE FRUTICULTURA, 17., 2002, Belém. Anais... Belém: SBF, 2002. 1 CD-ROM. 
PEREIRA, L. V.; REZENDE e SILVA, C. R. de; ALVARENGA, A. A. Comportamento de cultivares de bananeira oriundas de mudas de cultura de tecidos e convencionais. In: CONGRESSO BRASILEIRO DE FRUTICULTURA, 15., 1998, Poços de Caldas-MG. Anais... Sociedade Brasileira de Fruticultura e Universidade Federal de Lavras, 1998. p.125.

PEREIRA, L. V. et al. Características de pós-colheita e índice de aceitação pelos consumidores de novos cultivares de banana. In: congeresso brasileiro de fruticultura, 17. 2002, Belém. Anais... Belém: SBF, 2002. 1 CD-ROM.

PEREIRA, L. V. et al. Avaliação de cultivares e híbridos de bananeira em Lavras, MG. Ciência e Agrotecnologia, Lavras, v. 27, n. 1, p. 17-25, jan.Ifev. 2003.

PEREIRA, M.C.T. et al. Suscetibilidade à queda natural e caracterização dos frutos de diversos genótipos de bananeira. Revista Brasileira de Fruticultura, Jaboticabal, v.26, n.3, p.499-502, dez. 2004.

PINTO, A. C. de Q. Influência do ácido giberélico, do permanganato de potássio e da embalagem de polietileno na conservação e embalagem de banana 'Prata'. $1978.80 \mathrm{f}$. Dissertação (Mestrado em Fitotecnia)-Escola Superior de Agricultura de Lavras, Lavras, 1978.

RAIJ, B. van; QUAGGIO, J. A. Métodos de análises de solo para fins de fertilidade. Boletim Técnico do Instituto Agronômico de Campinas, Campinas, n. 81, p. 1-31, 1983.

RAIJ, B. van et al. Recomendações de adubação e calagem para o Estado de São Paulo. $2^{\mathrm{a}}$ Ed. ver. E atual. Campinas: Instituto Agronômico , 1997. 285 p. (Boletim técnico, 100).

RAMOS, D. P. Avaliação de genótipos de bananeira (Musa sp.) em Botucatu-SP. 2008. 125f. Dissertação (Mestrado em Agronomia / Horticultura). Faculdade de Ciências Agronômicas, Universidade Estadual Paulista, Botucatu, 2008.

RAMOS, D. P. et al. Crescimento, produção e qualidade de frutos da bananeira 'Figo Cinza', em Botucatu-SP. Revista Brasileira de Fruticultura, Jaboticabal, v. 31,n. 3, p. 749-754, setembro. 2009a.

RAMOS, D. P. et al. Avaliação de genótipos de bananeira em Botucatu-SP. Revista Brasileira de Fruticultura, Jaboticabal, v. 31,n. 4, p. 1092-1101, dez. 2009b. 
RANGEL, A.; PENTEADO, L. A. C.; TONET, R. M. Cultura da banana. Campinas: CATI, 2002. 91 P. (Boletim técnico, 234).

RODRIGUES, M. G. V. ; SOUTO, R. F.; SILVA, S. de O. Avaliação de genótipos de bananeira sob irrigação. Revista Brasileira de Fruticultura, Jaboticabal, v. 28,n. 3, p. 444448, dez. 2006.

ROSSGNOLI, P. A. Atmosfera modificada por filmes de polietileno de baixa densidade com diferentes espessuras para a conservação de banana 'Prata' em condições ambiente. 1983. 81 f. Dissertação (Mestrado em Ciências dos Alimentos)-Escola Superior de Agricultura de Lavras, Lavras, 1983.

SAES, L. A.; NOMURA, E. S.; GARCIA, V. A. Cultivares resistentes de bananeira. In: REUNIÃO INTINERANTE DE FITOSSANIDADE DO INSTITUTO BIOLÓGICO, 13. 2005, Registro. Anais... Registro: APTA, 2005. P. 51-58. Disponível em:

http://www.biologico.sp.gov.br/rifib/XIIIRifib/saes.pdf. Acesso em: 16 jul. 2008.

SALOMÃO, L. C. C. et al. Crescimento e produção de primeiro ciclo de bananeira (Musa spp.) 'Prata-anã' em sete espaçamentos, em Visconde de Rio Branco-MG. In: CONGRESSO BRASILEIRO DE FRUTICULTURA, 15., 1998, Poços de Caldas-MG. Resumos... Lavras: UFLA/SBF, 1998. p. 131.

SANTOS, S. C.; CARNEIRO, L. C.; SILVEIRA NETO, A. N. da.; PANIAGO JÚNIOR, E.; FREITAS, H. G. de; PEIXOTO, C. N. Caracterização morfológica e avaliação de cultivares de bananeira resistentes a Sigatoka-negra (Mycosphaerella fijiensis Morelet). No sudoeste goiano. Revista Brasileira de Fruticultura, Jaboticabal, v. 28, n. 3, p. 449-453, dez. 2006.

SANTOS, S. B. dos et al. Avaliação de genótipos promissores de banana do banco ativo de germoplasma da Embrapa Mandioca e Fruticultura. In: CONGRESSO BRASILEIRO DE FRUTICULTURA, 17., 2002, Belém. Anais... Belém: SBF, 2002. 1 CD-ROM.

SGARBIERI, V. C.. HEC, M.; LEONARD, S. J. Estudo bioquímico de algumas variedades de banana cultivadas no Brasil. Coletânea do Instituto de Tecnologia de Alimentos, Campinas, v. 1, n. 2, p. 527-558, 1965/66.

SILVA, S. de O. e; MATOS, A. P.; ALVES, E. J. Melhoramento genético da bananeira. Pesquisa Agropecuária Brasileira, Brasília, v. 33, n. 5, p. 693-703, maio 1998. 
SILVA, C.R. de R. e; SOUTO, R. F.; MENEGUCCI, J.L.P. Propagação da bananeira. Informe Agropecuário, Belo Horizonte, v. 20, n. 196, p. 16-20, jan.Ifev. 1999.

SILVA, S. de O. e et al. Cultivares. In: ALVES, E. J. (Org.). A cultura da banana: aspectos técnicos, socioeconômicos e agroindustriais. 2. ed. rev. Brasília: EMBRAPA, SPI, 1999. p. $85-105$.

SILVA,C. R. DE R.; SOUTO, R. F.; MENEGUCCI, J. L. P. Propagação da bananeira. Informe Agropecuário, Belo Horizonte, v. 20, n. 196, p. 16-20, jan./fev. 1999.

SILVA, S. de O. e et al. Melhoramento genético da bananeira. In: SIMPÓSIO BRASILEIRO DE MELHORAMENTO DE FRUTEIRAS, 2., 2000, Viçosa. Anais... Viçosa, MG: UFV, 2000. p. 21-48.

SILVA, S. de O. e; FLORES, J. C. de O.; LIMA, F. P. Avaliação de cultivares e híbridos de bananeira em quatro ciclos de produção. Pesquisa agropecuária Brasileira, Brasília, v.37, n. 11, p. 1567-1574, nov. 2002.

SILVA, S. de O. e; SANTOS-SEREJO, J. A. dos; CORDEIRO, Z. J. M. Variedades. In: BORGES, A. L.; SOUZA, L. da S. (Eds.) O cultivo da bananeira. Cruz das Almas: EMBRAPA Mandioca e Fruticultura, 2004. p. 45-58.

SIMÃO, S. Manual de fruticultura. São Paulo: Ceres, 1985. p.327-377.

SIMMONDS, N. W. Banana. Ed Western Printing Service Ltda., 446 p., 1960

SOTO BALLESTERO, M. Bananas: cultivo y comercialización. 2. ed. San José: Litografia e Imprensa, 1992. $674 \mathrm{p}$.

TEIXEIRA, E.;MEINERT, E. M.; BARBETTA, P. A. Análise sensorial de alimentos. Florianópolis: UFSC, 1987. 180p. (Série Didática).

TEIXEIRA, L. A. J. et al. Banana. Boletim Técnico do Instituto Agronômico de Campinas, Campinas, n. 100, p. 131-132, 1997. 
TUNER, D. W. Postharvest and storage of tropical and subtropical fruits. Bananas and plantains. In: MITRA, S. Postharvest and storage of tropical and subtropical fruits. Wallingford: CAB Internacional, 2001. P. 47-77.

VIEIRA, D. P. Esperam-se progressos na bananicultura. AGRIANUAL 2005: Anuário Estatístico da Agricultura Brasileira, São Paulo, p. 221-225, 2004.

VILAS BOAS, E. V. de B. Modificações pós-colheitas de banana 'Prata' (Musa acuminata X Musa balbisiana, grupo AAB) $\gamma$-irradiada. 1995. 75p. (Dissertação de Mestrado) Universidade Federal de Lavras, Lavras 1995.

VILAS BOAS, E. V. de B, et al. Características da fruta. In MATSUURA, F. C. A. U; FOLEGATTI, M. I. S. (Eds.). Banana. pós-colheita. Brasília, DF: EMBRAPA Informação Tecnológica, 2001. 71 p. (Série frutas do Brasil,16). 


\section{APÊNDICE I}

\section{U 1050 Universidade Estadual Paulista Faculdade de Medicina de Botucatu}

Distrito Rubião Junior, $s / n^{\circ}$ - Botucatu - S.P. CEP: $18.618-970$

Fone/Fax: (0xx14) 3811-6143

e-mail secretaria: capellup@fmb.unesp.br

e-mail coordenadoria: tsarden@fmb.unesp.br

Botucatu, 07 de dezembro de 2.009

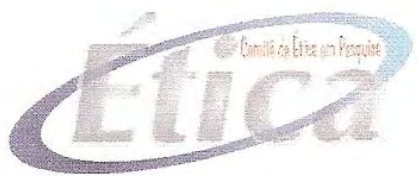

Registrado no Ministério da Saúde em 30 de abril de 1997

OF. 479/2009-CEP

Ilustríssima Senhora

Prof ${ }^{a}$. Dr ${ }^{a}$. Sarita Leonel

Departamento de Produção Vegetal da

Faculdade de Ciências Agronômicas Botucatu

Prezada Dra Sarita,

De ordem do Senhor Coordenador deste CEP, informo que Projeto de Pesquisa (Protocolo CEP 3416-2009) "Avaliação agronômica e sensorial de cultivares de bananeira na região de Botucatu-SP", a ser conduzido por Manoel Euzébio de Souza, orientado pela Prof ${ }^{a}$. Dr ${ }^{a}$ Sarita Leonel, recebeu do relator parecer favorável, aprovado em reunião de 07 de dezembro de 2.009.

Situação do Projeto: APROVADO. Ao final da execução deste Projeto, apresentar ao CEP "Relatório Final de Atividades".

Atenciosamente,

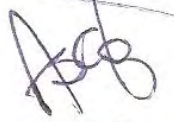

Alberto Santos Capelluppi

Secretário do CEP 


\section{APÊNDICE II}

Ficha utilizada na análise sensorial.

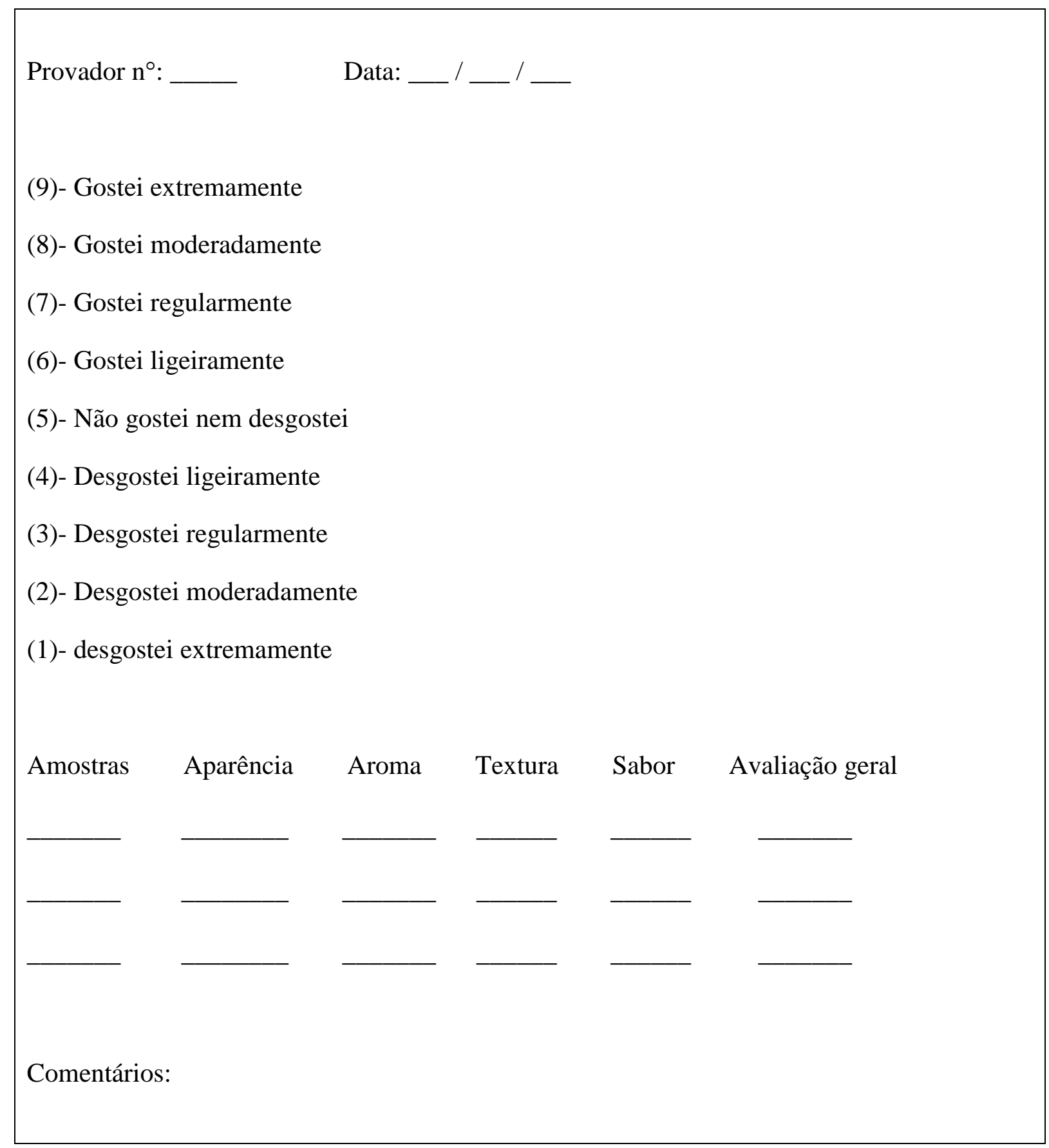

